\title{
California GAMA Special Study: Nitrate Fate and Transport in the Salinas Valley
}

Jean E. Moran*, Bradley K. Esser, Darren Hillegonds, Marianne Holtz*, Sarah K.

Roberts, Michael J. Singleton, and Ate Visser

Lawrence Livermore National Laboratory

${ }^{*}$ California State University, East Bay

\section{March, 2011}

Final Report for the California State Water Resources Control Board

GAMA Special Studies Task 10.5:

Surface water-groundwater interaction and nitrate in Central Coast streams 


\section{Disclaimer}

This document was prepared as an account of work sponsored by an agency of the United States government. Neither the United States government nor Lawrence Livermore National Security, LLC, nor any of their employees makes any warranty, expressed or implied, or assumes any legal liability or responsibility for the accuracy, completeness, or usefulness of any information, apparatus, product, or process disclosed, or represents that its use would not infringe privately owned rights. Reference herein to any specific commercial product, process, or service by trade name, trademark, manufacturer, or otherwise does not necessarily constitute or imply its endorsement, recommendation, or favoring by the United States government or Lawrence Livermore National Security, LLC. The views and opinions of authors expressed herein do not necessarily state or reflect those of the United States government or Lawrence Livermore National Security, LLC, and shall not be used for advertising or product endorsement purposes.

\section{Auspices Statement}

This work performed under the auspices of the U.S. Department of Energy by Lawrence Livermore National Laboratory under Contract DE-AC52-07NA27344. 


\section{GAMA: AMBIENT GROUNDWATER \\ Monitoring \& Assessment Program \\ SPECIAL STUDY}

\section{California GAMA Special Study:}

\section{Nitrate Fate and Transport in the Salinas Valley}

Jean E. Moran*, Bradley K. Esser, Darren Hillegonds, Marianne Holtz*, Sarah K. Roberts, Michael J. Singleton, and Ate Visser

Lawrence Livermore National Laboratory

*California State University, East Bay

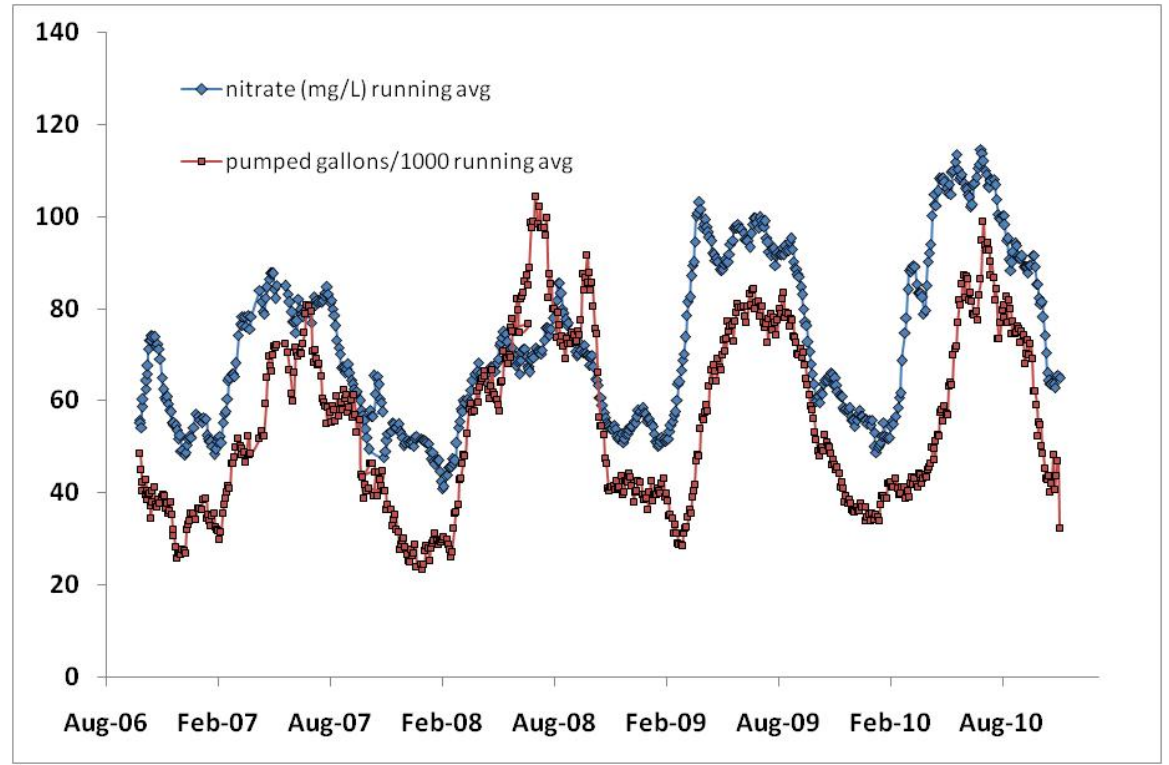

Prepared in cooperation with the California

State Water Resource Control Board

Final Report for GAMA Special Studies Task 10.5:

Surface water-groundwater interaction and nitrate in Central Coast streams

LLNL-TR-484186

September 2011 


\section{Suggested citation:}

Jean E. Moran, Bradley K. Esser, Darren Hillegonds, Marianne Holtz, Sarah K. Roberts, Michael J. Singleton, and Ate Visser (2011) California GAMA Special Study: Nitrate Fate and Transport in the Salinas Valley. Lawrence Livermore National Laboratory LLNL-TR-484186. 


\title{
California GAMA Special Study: Nitrate Fate and Transport in the Salinas Valley
}

\author{
By Jean E. Moran*, Bradley K. Esser, Darren Hillegonds, Marianne Holtz*, Sarah K. \\ Roberts, Michael J. Singleton, and Ate Visser
}

Lawrence Livermore National Laboratory, *California State University, East Bay

Prepared in cooperation with the California State Water Resource Control Board

\section{Executive Summary}

The Groundwater Ambient Monitoring and Assessment (GAMA) Program is a comprehensive groundwater quality monitoring program managed by the California State Water Resources Control Board (SWRCB). Under the GAMA program, Lawrence Livermore National Laboratory carries out special studies that address groundwater quality issues of statewide relevance. The study described here is one in a series of special studies that address the fate and transport of nitrate in basins where groundwater is the main source of water for both irrigation and public drinking water supply.

The Salinas Valley, known as 'the salad bowl of the world', has been an agricultural center for more than 100 years. Irrigated row crops such as lettuce and strawberries dominate both land use and water use in the valley. The most common water quality issue that arises from this type of intensive agriculture is contamination of groundwater by nitrate from fertilizers. This study focuses on three key aspects of nitrate fate and transport in the Salinas Valley groundwater basin: 1) establishing background conditions for nitrate in a comparatively un-impacted portion of the basin, 2) examining the fate and transport of nitrate near the recharging Salinas River, and 3) determining the source of nitrate in a highly impacted drinking water well.

Establishing an approximate background nitrate concentration is important because native plants, certain rocks and sediments, and rainwater are natural sources of nitrate which may have highly variable inputs to surface water and groundwater. Furthermore, geochemical processes such as denitrification can decrease nitrate concentrations in surface water and groundwater, masking contributions from both natural and non-natural sources. For the Salinas Valley, the Arroyo Seco (a tributary to the Salinas River) serves as a "background" location with respect to nitrate because land cover is predominantly natural and the river and groundwater are relatively pristine. Very low concentrations of nitrate (less than 4 $\mathrm{mg} / \mathrm{L}$ as $\mathrm{NO}_{3}{ }^{-}$) are observed in wells adjacent to Arroyo Seco and in Arroyo Seco surface water. Nitrate concentrations in groundwater (mean of $1.21 \mathrm{mg} / \mathrm{L}$ ) and surface water (mean of $0.11 \mathrm{mg} / \mathrm{L}$ ), along with other chemical and isotopic indicators, suggest that nitrate found in these samples comes from rain, with a small additional contribution of nitrate from the soil zone found in groundwater samples. The isotopic composition of nitrate in these samples also reflects its natural source. 
Transport of water and solutes in areas adjacent to the Salinas River was examined in three ways: 1) physical measurements of groundwater elevation compared to stream elevation and streamflow with time over the past four years, 2) comparison of geochemical and isotopic constituents measured in Salinas River water over a seasonal hydrograph with the same constituents measured in monitoring wells adjacent to the river, and 3) comparison of geochemical and isotopic constituents analyzed in monitoring wells adjacent to the river with the same constituents measured in public drinking water wells from throughout the Salinas Valley. Pressure transducers in two sets of nested monitoring wells near the Salinas River at Chualar and Gonzales show that the river is strongly losing throughout the year in those reaches. Examination of groundwater ages, nitrate concentrations, and nitrate isotopic composition in the nested monitor wells reveals the fate of nitrate in recharging river water and addition of nitrate applied at the land surface. On average, the Chualar and Gonzales monitor wells samples $(n=13)$ have a lower nitrate concentration $(1.9 \mathrm{mg} / \mathrm{L})$ than the Salinas River samples from 2010 $(6.2 \mathrm{mg} / \mathrm{L} ; \mathrm{n}=10)$. These wells and other monitor well samples with much higher nitrate concentrations show evidence for denitrification, either by isotopic compositions that are enriched in ${ }^{15} \mathrm{~N}$ and ${ }^{18} \mathrm{O}$, or by the presence of excess dissolved nitrogen. Denitrification is therefore an important process in reducing nitrate concentrations in groundwater near the river.

One deep drinking water supply well which supplies water for the San Jerardo Cooperative was sampled eight times from May through December, 2010, and the nitrate concentration varied from 69 to 130 $\mathrm{mg} / \mathrm{L}$, well above the regulatory limit for drinking water of $45 \mathrm{mg} / \mathrm{L}$. The isotopic composition of nitrate falls in the range expected for inorganic fertilizers, and not in the range expected for animal waste. Denitrification is not taking place in the San Jerardo area because groundwater contains a high concentration of dissolved oxygen. An annual cycle in nitrate concentration is closely correlated with the annual cycle in pumping for irrigation, suggesting that high-nitrate irrigation return water is drawn into the well capture zone, particularly when the irrigation season begins in early spring. Irrigation water is pumped from deep aquifers, where groundwater has a low tritium concentration; this water makes its way back down to the well capture zone, entraining nitrate from applied inorganic $\mathrm{N}$-fertilizer along the way.

In summary, geochemical and isotopic results indicate that irrigated agriculture is the largest source of nitrate to groundwater and surface water in sampled areas where nitrate concentrations are above a very low background concentration. Nitrate concentrations are reduced by denitrification in subsurface environments with low dissolved oxygen, as encountered in monitor wells adjacent to the Salinas River. Nitrate isotopic compositions, when adjusted for partial denitrification and variable degrees of isotopic enrichment, are consistent with an inorganic fertilizer source in samples with nitrate concentrations above the background level. Regional groundwater pumping for irrigation accelerates groundwater flow such that high nitrate groundwater reaches the capture zone of some drinking water wells. Which areas are affected depends upon aquifer heterogeneity and vertical transport pathways, along with pumping patterns and connections to sources of irrigation return flow. 


\section{INTRODUCTION}

The Salinas Valley, known as 'the salad bowl of the world', has been an agricultural center for more than 100 years. Irrigated row crops such as lettuce and strawberries dominate both land use and water use in the valley. Water for irrigation as well as for municipal supply comes almost exclusively (83\%) from groundwater in the Salinas Valley and is of vital importance to the local economy and to the well being of the population. The most common water quality issue that arises from intensive row crop agriculture is contamination of groundwater by nitrate from fertilizers (Bohlke, 2002; Bohlke and Denver, 1995; Nolan, 2001). Adverse health effects associated with drinking water that has elevated nitrate concentrations have prompted the U.S. Environmental Protection Agency to establish a Maximum Contaminant Level (MCL) for nitrate in drinking water of $10 \mathrm{mg} / \mathrm{L}$ as $\mathrm{N}$. Increased loading of nitrogen to streams due to runoff from farms or influx of nitrate-laden groundwater to streams is also of concern because unnaturally high nitrate concentrations can lead to eutrophication of streams and coastal waters (Neal and Jarvie, 2005).

Some irrigation wells and most public water supply wells in the Salinas Valley are constructed to draw water from deep portions of the aquifer system, where contamination by nitrate is less likely than in the shallow portions of the aquifer system. Public drinking water supply wells are frequently tested for nitrate and many other constituents, while private domestic wells, which are more likely to tap shallow groundwater, are under no regulatory program that requires testing for nitrate or other constituents.

The Monterey-Salinas area is one of the 35 study units under the statewide priority basin project of the GAMA program, and 94 public supply wells distributed across a sampling grid were sampled in JulyOctober, 2005. The wells included in the present study are within two sub-units of the GAMA priority basin study, the Monterey Bay and Salinas Valley study areas in which 48 and 19 public supply wells were sampled, respectively. A description of the hydrogeologic setting of the Salinas Valley is found in the GAMA priority basin data summary report (Kulongoski et al., 2007) and in Fogg et al. (1999). Briefly, the Salinas Valley Groundwater Basin is an elongate basin extending approximately 80 miles inland and ranging in width from 2 to 14 miles. It is bounded by the Sierra de Salinas to the west and the Gabilan and Diablo Ranges to the east, and is drained by the Salinas River and its tributaries. Several hydrologically connected subbasins in the Salinas Valley groundwater basin are recognized by the CA Dept. of Water Resources, distinguished on the basis of recharge sources and hydrostratigraphy (California DWR, 2003; Kennedy Jenks, 2004).

Wells discussed in this study come from the Upper, Forebay, East Side, and 180/400 Foot (locally known as "Pressure") subbasins (Figure 1). Water bearing units comprise unconsolidated and semi-consolidated alluvial fan and river deposits which become interbedded with marine clays in the northern (Pressure) portion of the basin. Episodic changes in sea level during Miocene through Pleistocene times led to alternating deposition between coarse grained materials in riverine and alluvial fan environments, and fine grained sediments in estuarine and marine environments. The groundwater basin contains three main aquifers (separated in the Pressure area by clay aquitards), the 180 Foot, 400 Foot and 900 Foot 
aquifers, named for the average depths at which they are found. The aquitard separating the 180 Foot and 400 Foot aquifers is interbedded with sands, and is thin or absent in some parts of the basin. The confining unit above the 180 Foot aquifer pinches out to the southeast (around Chualar), and in the Forebay subbasin, the upper aquifer is unconfined. Upstream of the confluence of Arroyo Seco, the aquitard above the 400 Foot aquifer also becomes discontinuous and only the 900 Foot aquifer is confined. The East Side subbasin contains the same aquifers as the 180/400 Foot subbasin, but the confining layer above the 180 Foot aquifer is highly discontinuous or absent.

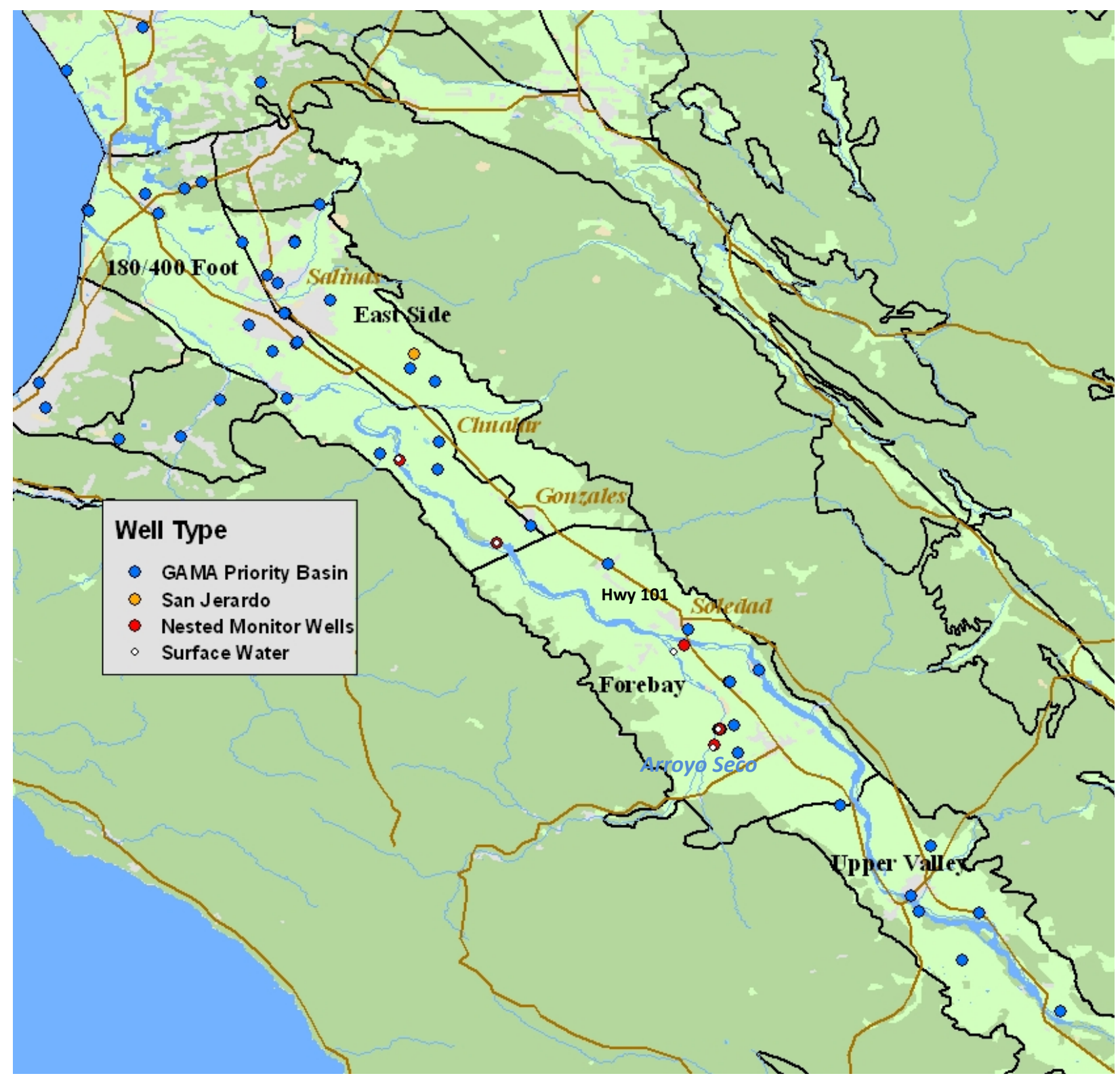

Figure 1. Sampling locations for the Salinas groundwater basin nitrate study, including wells within the study area sampled under the GAMA priority basin program (Kulongoski and Belitz, 2006). Five sets of nested wells, screened over different depths, are located adjacent to the Salinas River and Arroyo Seco (red symbols). Also shown are the location of the San Jerardo Co-op drinking water well (orange symbol) 
and four surface water sampling locations (white symbols). Black lines and labels show the boundaries of CA Department of Water Resources-defined subbasins within the Salinas Valley Groundwater Basin (DWR, Bulletin 118), brown lines show major roads. Grey-shaded areas represent municipal-residential land use, dark green areas cover range land and forested land, and light green represents areas of irrigated agricultural land use.

Recharge to Salinas Valley aquifers takes place along the Salinas River, the flow along which is seasonally controlled for conjunctive use. Releases during dry periods are from Santa Margarita Lake and along tributaries at the Nacimiento and San Antonio Reservoirs. Distributed recharge and stream recharge occurs during and following precipitation events, and peak flows in the river occur after large rain events, typically in January through March. Rainfall amounts vary with distance from the ocean, from 30 inches per year near Monterey Bay to 11 inches per year at Soledad, and are greater at higher elevations. The free-flowing Arroyo Seco tributary drains a large, steep catchment and the stream and Arroyo Seco cone sediments are important sources of recharge in the Forebay subbasin (estimated at 75,000 acre-ft/yr; Fogg et al., 1995). In addition to recharge from precipitation and streams, excess water applied via sprinkler and furrow irrigation returns to recharge the aquifer system.

Fogg et al. (1995) and MCWRA (1997)make independent estimates of the water budget for the portion of the Salinas Valley within the study area. Discharge is solely by groundwater pumping, at approximately 500,000 acre-ft/yr. Inputs to the basin are dominated by recharge via the Salinas River (and tributaries) and irrigation return flow in both studies, but Fogg et al. (1995) assign a greater portion to irrigation return flow. Precipitation, subsurface and boundary inflow, and seawater intrusion are other sources of water of lesser importance. Major water supply and water quality issues in the Salinas Valley include continuing overdraft of aquifers, especially in the East Side subbasin where water levels have dropped by 80 feet or more over the past several decades, seawater intrusion caused by overdraft that stretches more than 5 miles inland in the 180 Foot aquifer and 3 miles inland in the 400 Foot aquifer, and contamination in some areas by nitrate and other non-point source pollutants (California DWR, 2003).

Nitrate contamination varies considerably depending on which aquifer(s) and which subbasins are examined. From 1994 through 2000, 69 of 711 or $9.7 \%$ of public supply wells tested in the Salinas Valley Groundwater Basin exceeded the MCL for nitrate (California DWR, 2003). In the GAMA data summary report for Monterey-Salinas, only 2 wells of 34 (5.8\%) sampled for nitrate had detections higher than the MCL (Kulongoski et al., 2007). The sample set for the GAMA study consisted of 31 public drinking water wells and 3 monitoring wells, many of which have relatively deep top perforations (figure 2). However, when agricultural (irrigation) wells and dedicated monitoring wells were tested, a much higher proportion of wells had nitrate concentrations above the MCL (MCWRA, 1997; Section 6). For example, in the East Side and Forebay subbasins, 62 of 149 or $42 \%$, of wells tested were above the MCL, and the average nitrate concentration in each of these subbasins was above the MCL. Exceedance frequencies and average concentrations are lower in the 180 Foot and 400 Foot aquifers than in the Eastside and Forebay subbasins. However, the average concentration for 78 wells from the 180 Foot aquifer in the Pressure area was $35 \mathrm{mg} / \mathrm{L}$, indicative of a significant component of non-natural nitrate. Furthermore, 
extremely high concentrations, above $100 \mathrm{mg} / \mathrm{L}$ and up to $681 \mathrm{mg} / \mathrm{L}$ are observed sporadically in all of the subbasins. These nitrate 'hot spots' are discussed further below. Irrigation wells are more likely to tap shallow aquifers or multiple aquifer zones than drinking water wells, which are commonly screened exclusively in deep aquifers below major confining units. The exceedance statistics are also affected by the fact that drinking water wells may be abandoned (and no longer tested) because of poor water quality.

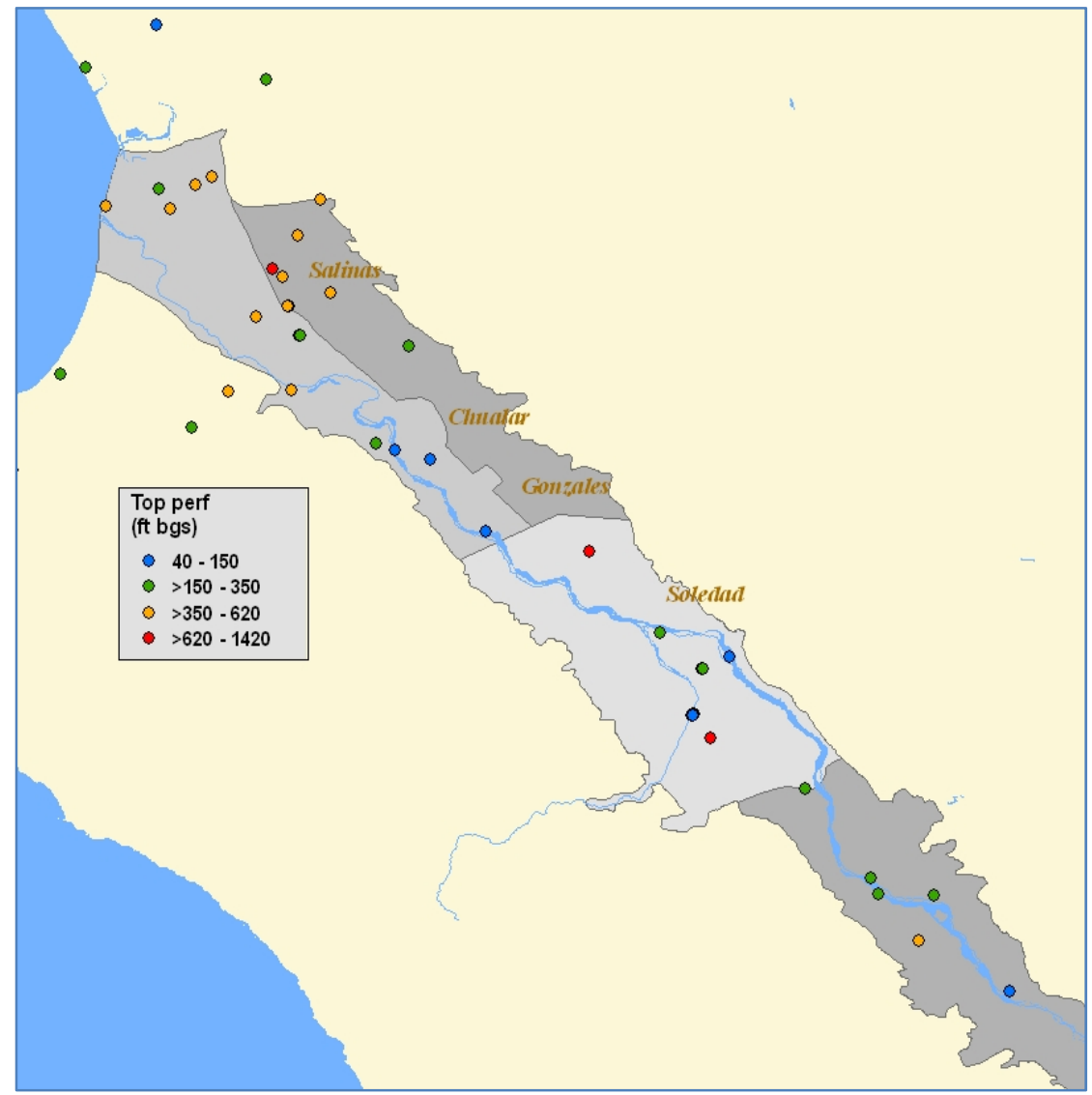

Figure 2. GAMA priority basin wells and wells from this study labeled according to the depth to the top perforation. (Well types as shown on figure 1.)

Kulongoski and Belitz (2011) used a non-parametric statistical analysis to examine the relationship between nitrate and potential explanatory factors including land use, top perforation of well, groundwater age, and geochemical condition (e.g., dissolved oxygen, pH). They found that nitrate concentrations were slightly higher in wells with groundwater ages classified as modern or mixed compared to wells classified as pre-modern, and that wells classified under urban/agricultural land use have higher nitrate concentrations than wells classified under natural land use. In addition, nitrate was correlated positively with percent agricultural land use and dissolved oxygen, and correlated negatively with $\mathrm{pH}$ and groundwater discharge temperature. The four wells (of 64 included in the analysis, some of which were from the CA Department of Public Health Title 22 database not sampled under GAMA) with nitrate results higher than the $\mathrm{MCL}$ are classified as urban/agricultural land use, modern or mixed 
groundwater age, and have top perforations of less than $200 \mathrm{ft}$. Another significant finding that bears upon the fate of nitrate in Salinas Valley groundwater is that unlike many basins where forebay portions of the basin are oxic and low TDS, and confined ('pressure') zones are anoxic and higher TDS, the GAMA study found roughly the opposite pattern in the Salinas Valley. According to the authors, dilution of groundwater along flowpaths may be the result of addition of low TDS reservoir water used for irrigation or low TDS reservoir water recharging through the river bed, resulting in lower TDS in downgradient portions of the basin. Anoxic/suboxic groundwaters were found in the upper portion of the valley and in the lowermost portion, but oxic groundwaters were found throughout the medial portion, from 25 to 75 miles downstream in the 80 mile basin.

An understanding of the sources of nitrate to streams and groundwater, and of the fate of nitrate in streams and groundwater is of critical importance in agricultural areas where nutrient management on farms is a key component of nitrate source control. Nitrogen may be applied to crops in various forms such as animal manure, anhydrous ammonia, urea, ammonium sulfate, calcium nitrate, or ammonium nitrate, but all forms may eventually be converted to nitrate and transported away from the shallow soil zone to streams or groundwater. Denitrification, which converts nitrate to nitrogen or nitrous oxide gas, can mitigate nitrate loading to streams and groundwater, and can occur in any zone where certain geochemical conditions are met, viz. low oxygen, the presence of an electron donor such as organic carbon or reduced sulfur, and a population of denitrifying bacteria. The hyporheic zone of streams, riparian buffer zones, poorly drained soils, and saturated zones with low dissolved oxygen are all environments where bacteria are generally present and conditions favorable for denitrification may exist.

Recent research has highlighted the importance of the streambed environment in the process of denitrification (Bernhardt et al., 2002; Butturini and Sabater, 1999; Grimaldi and Chaplot, 2000; Puckett and Cowdery, 2002; Puckett et al., 2008). Two recent studies carried out in California are particularly instructive for comparing nitrate dynamics in a gaining (the Merced River near Turlock, CA; Domagalski et al., 2008) versus a losing stream (the Parajo River; Ruehl et al., 2007). These two studies employ natural and introduced geochemical and isotopic tracers to assess water exchange and nitrate source and transformation in stream water and shallow groundwater. Denitrification is documented using comparisons of nitrate concentrations with other ions, patterns in stable isotopes of $\mathrm{N}$ and $\mathrm{O}$, and dissolved excess nitrogen.

In the Merced River study, nitrate, determined from stable isotopes of $\mathrm{N}$ and $\mathrm{O}$ to be from fertilizer applications to nearby almond orchards, is found in groundwater near the river at well depths of up to $27 \mathrm{~m}$ bgs. Groundwater with nitrate concentrations of up to $93 \mathrm{mg} / \mathrm{L}\left(\mathrm{as} \mathrm{NO}_{3}{ }^{-}\right.$) is transported toward the Merced River where it discharges to the river at an estimated rate of $18 \mathrm{~L} / \mathrm{s}$ per river $\mathrm{km}$. Some denitrification takes place within the shallow aquifer but subsequent transport of nitrate across a riparian zone and to the stream/groundwater interface results in higher rates of denitrification (Domagalski et al., 2008). Discharging groundwater near the center of the river channel contains no nitrate and only excess nitrogen gas from denitrification. Older groundwater transported in deeper 
flowpaths contains little nitrate, either because it had less nitrate initially or because it had experienced denitrification.

A similarly detailed study of nitrate dynamics within the Pajaro River showed that denitrification is also an important process in a losing stream (Ruehl et al., 2007). Land use, water use and climatic conditions in the Pajaro Valley are similar to those in the Salinas Valley, but concentrations of nitrate in the Pajaro River are higher than those observed in the Salinas River, and commonly exceed the MCL for drinking water. Time series analysis of river water chemistry shows that nitrate concentrations decrease downstream while concentrations of other major ions remain unchanged. Spatial and temporal variability in the rate of denitrification was observed over the $11 \mathrm{~km}$ reach, which was examined over time scales from hours to months. Most of the loss of nitrate by denitrification occurs where seepage loss and surface-subsurface exchange are most rapid, and denitrification efficiency is greatest at times of low stream discharge (resulting in a lower apparent isotopic fractionation of $\mathrm{N}$ and $\mathrm{O}$ ). Similar processes of denitrification are expected in the hyporheic zone of the losing Salinas river.

The goals of the present study are: 1) to establish background conditions for nitrate in an un-impacted portion of the basin, 2) to examine the fate and transport of nitrate near the recharging Salinas River and 3) to determine the source of nitrate in a highly impacted drinking water well in East Side subbasin. Compared to the Merced River and Pajaro River studies, this study is focused on transport of water and nitrate away from the river over a longer time period, as observed in wells directly affected by river recharge but screened over deeper intervals (50-300 ft) and intercepting water with longer subsurface residence times than the above-mentioned studies. Compared to GAMA priority basin and MCWRA monitoring studies, this study covers a limited spatial extent, but uses multiple physical, geochemical, and isotopic tools to examine the source and transport of nitrate in detail. 


\section{RESULTS}

\section{Background Nitrate Levels: the Arroyo Seco Cone}

Because land cover is predominantly natural, the Arroyo Seco watershed is relatively pristine and unaffected by significant non-natural nitrate inputs, and thus serves as a 'background' location in the Salinas Valley with respect to nitrate. Natural chaparral and oak woodland landscapes dominate much of the Arroyo Seco watershed, although vineyards cover the lower slopes and floodplain in the lower reaches, near the confluence with the Salinas River (figure 3). Lower water use and lower nitrogen application are expected over these relatively recent vineyards, in comparison with row crops prevalent for several decades in other parts of the Salinas Valley. Establishing an approximate background nitrate concentration is important because native plants, certain rocks and sediments, and rainwater are natural sources of nitrate which may have highly variable inputs to surface water and groundwater. Furthermore, geochemical processes such as denitrification can decrease nitrate concentrations in surface water and groundwater, masking contributions from both natural and non-natural sources.

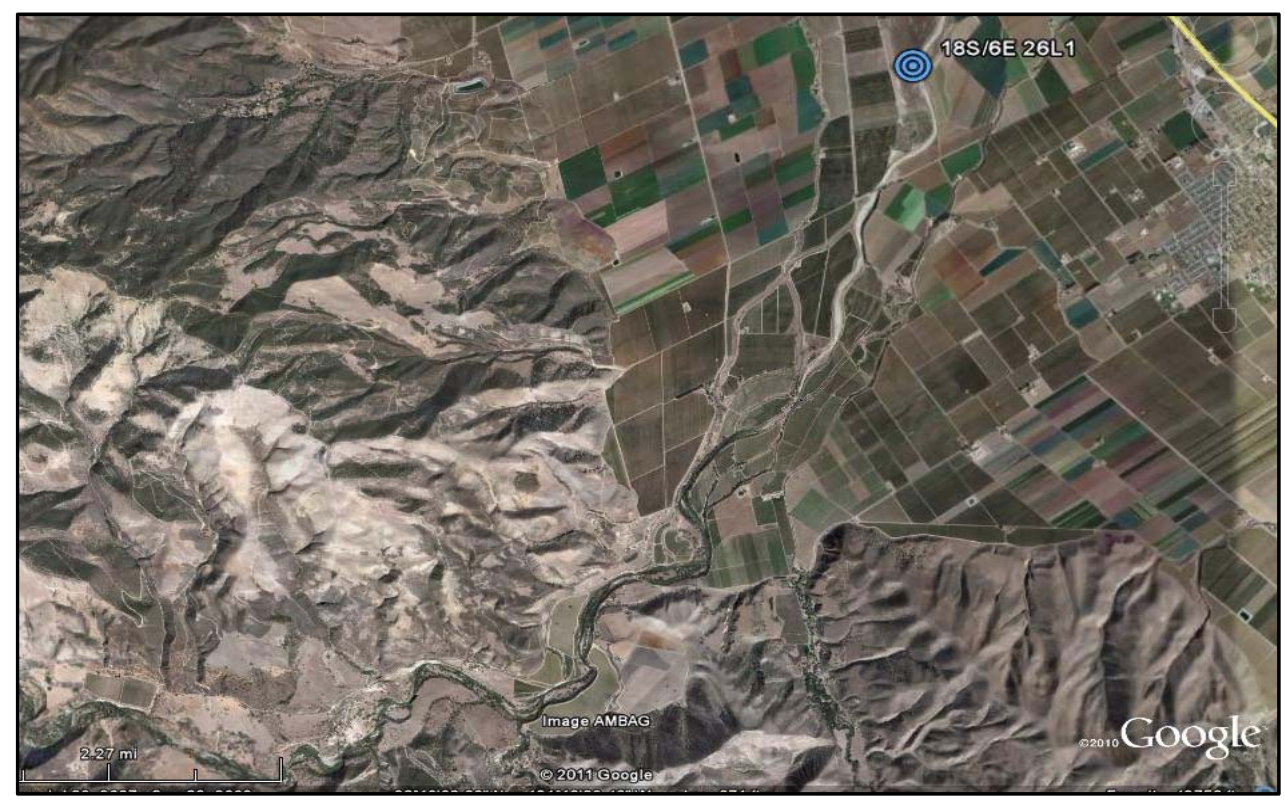

Figure 3. Location of Arroyo Seco well cluster adjacent to Arroyo Seco. Land cover in most of the watershed is natural, with vineyards occupying the lower-most portion of the watershed.

Very low concentrations of nitrate (less than $4 \mathrm{mg} / \mathrm{L}$ as $\mathrm{NO}_{3}{ }^{-}$) are observed in wells adjacent to Arroyo Seco and in Arroyo Seco surface water (Table $1 \mathrm{~b}$ and figure 4). Most samples have concentrations of less than $1 \mathrm{mg} / \mathrm{L}$, a value in the range of total nitrogen concentrations observed in rainwater along the California coast (NADP, 2002). A comparison between surface water and groundwater shows that nitrate is somewhat higher in groundwater (mean of $1.21 \mathrm{mg} / \mathrm{L}$ ) than in surface water (mean of 0.11 $\mathrm{mg} / \mathrm{L}$ ), suggesting that nitrate found in these samples comes from rain, with a small additional 
contribution of nitrate from the soil zone in groundwater samples (additional evidence for a rainwater source for water and solutes in this area is given below).

Radon in shallow nested monitor wells (18S/06E-26L01, -26K01, -26K02, and -26K03) near the Arroyo Seco River is relatively constant at 360-400 pCi/L Rn-222 (Table 1D). Surface water measured in Arroyo Seco Creek at the well site in mid-December 2009 and at a bridge immediately upstream of the well site in May 2010 did not have detectable radon ( $<8 \mathrm{pCi} / \mathrm{L} \mathrm{Rn-222).} \mathrm{Flow} \mathrm{during} \mathrm{both} \mathrm{sampling} \mathrm{events} \mathrm{was}$ moderate, i.e. flow measured as the upstream Arroyo Seco Near Soledad gauge (127-164 cfs) was significantly lower than peak flows (several thousand cfs) and significantly higher than low flows (10-20 cfs). Groundwater influx to surface water under these moderate flow conditions is limited by the radon data to be less than $2 \%$ by volume, a finding consistent with a predominantly losing stream and a precipitation source for nitrate in the stream.

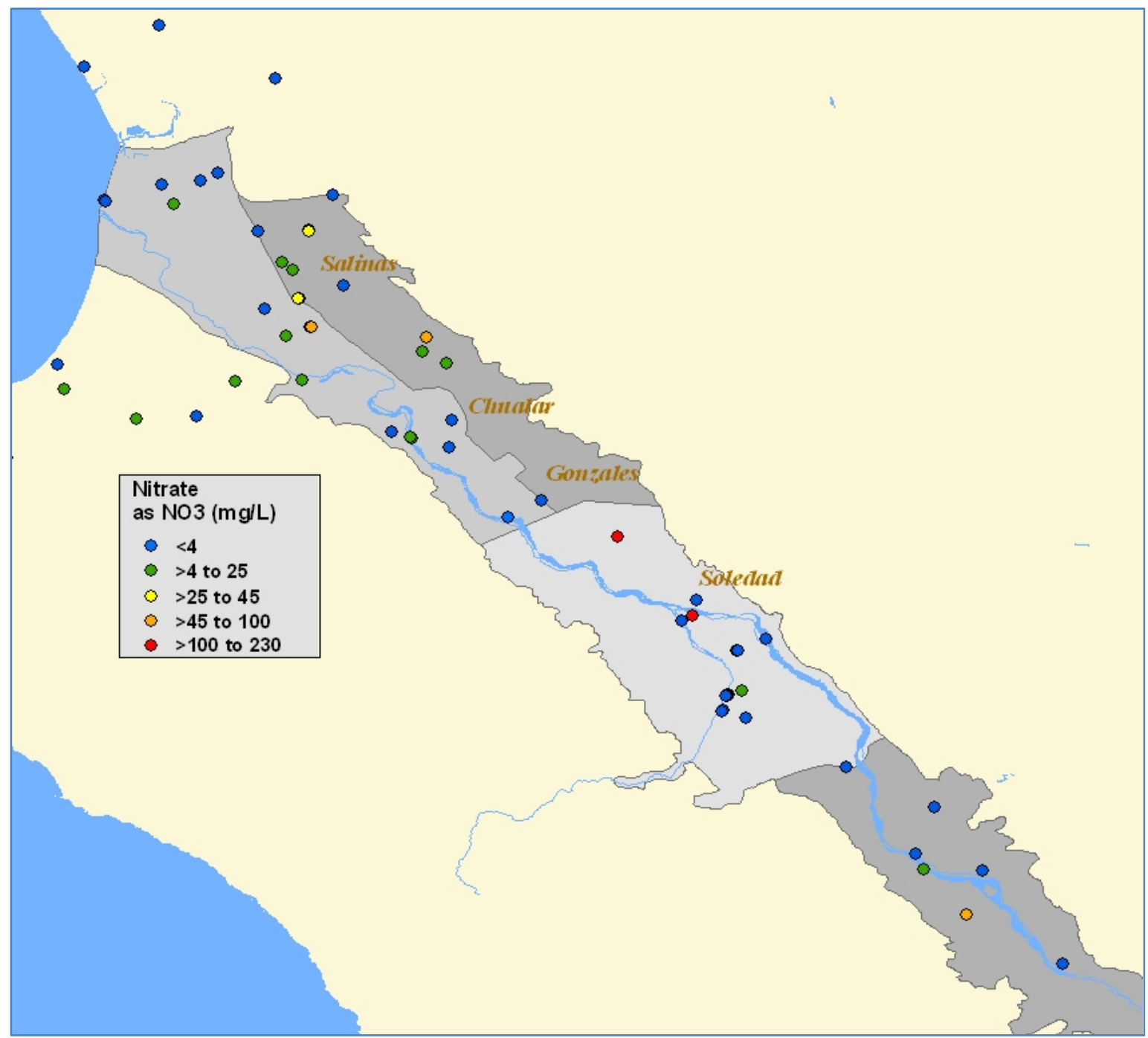

Figure 4. Nitrate concentrations in monitor wells from this study and in GAMA priority basin wells. (Well types as shown on figure 1.) 
The nitrate concentrations observed in samples from the Arroyo Seco area have not been affected by denitrification. Dissolved oxygen concentrations in groundwater are too high for denitrification to take place in the saturated zone, and there is no significant decrease in nitrate concentrations between surface water and groundwater. Furthermore groundwater samples from the Arroyo Seco area have $\mathrm{N}_{2}$ /Ar ratios and dissolved oxygen concentrations that are similar to concentrations in air saturated water (figure 5), with no excess nitrogen from denitrification. Very low nitrate concentrations are likewise observed in wells screened in the 400 Foot aquifer of the Pressure zone (only 38 out of 116 wells tested had nitrate concentrations $>3 \mathrm{mg} / \mathrm{L}$; MCWRA, 1997). Thus, an estimated background nitrate concentration of $<4 \mathrm{mg} / \mathrm{L}$ is consistent between these two Salinas Valley aquifers which are unlikely to be affected by anthropogenic nitrate. (However, data are not available to assess denitrification in deep Pressure zone wells.)

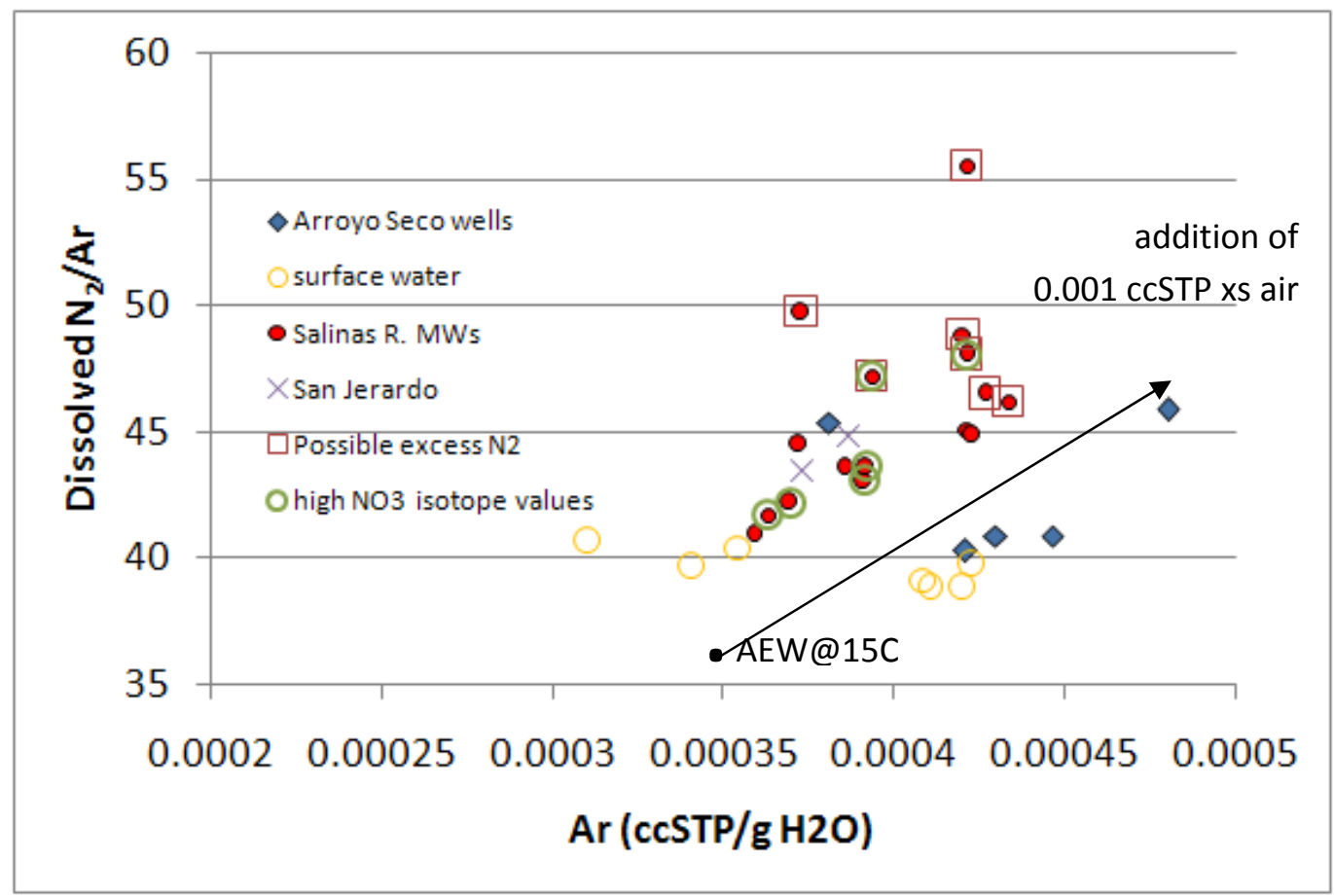

Figure 5. Results of analysis of the major dissolved gases are used to interrogate samples for evidence of saturated zone denitrification. As displayed on the plot of Ar vs. $\mathrm{N}_{2} / A r$, denitrification is possible in samples with elevated ratios of $\mathrm{N}_{2} / A r$. All of the monitoring wells near the Salinas River have low dissolved oxygen concentrations and $N_{2}$ /Ar ratios that suggest denitrification may be taking place. (Dissolved gas concentrations are also affected by temperature and addition of excess air; the arrow shows the trend for minimal addition of excess air - most groundwater samples, and especially the San Jerardo samples, have higher excess air concentrations, which accounts for some of the scatter above the line. Values for air equilibrated water at $15^{\circ} \mathrm{C}$ are also shown for reference.) 


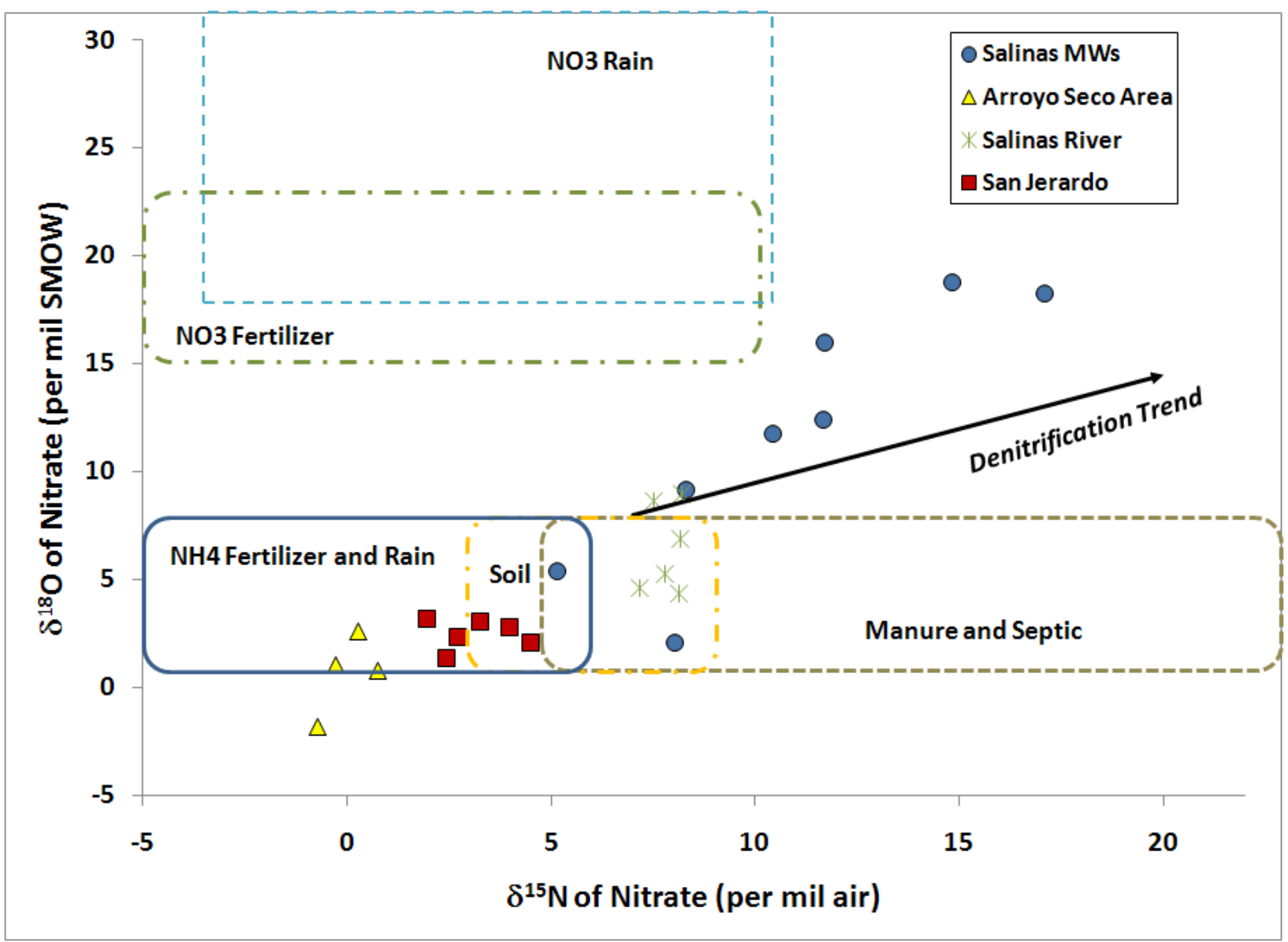

Figure 6. Plot of nitrogen and oxygen isotope ratios in nitrate. Overlapping fields typical for the sources indicated are shown as boxes. The oxygen isotope ranges for nitrate sources derived from nitrification (all fields except "NO3 Fertilizer" and "NO3 Rain") are modified after Kendall (1998) to reflect the range (+/- 2 standard deviations ) of oxygen isotope compositions in water from this study. For reference, an arrow is shown along a slope of $1 / 2$, which is the expected effect of denitrification on residual nitrate.

Since nitrate concentrations suggest a natural nitrate source in the Arroyo Seco area, the isotopic composition of nitrate in these samples should also reflect its natural source. Very low surface water nitrate concentrations preclude determination of nitrate isotopes $\left(\delta^{15} \mathrm{~N}\right.$ and $\delta^{18} \mathrm{O}$ of nitrate) in Arroyo Seco surface water. However, as shown on figure 6, the low-concentration groundwater samples from the Arroyo Seco area are tightly grouped around $0 \% \circ \delta^{15} \mathrm{~N}, 0 \%$ o $\delta^{18} \mathrm{O}$. Both soils fertilized with synthetic nitrate and rain water samples typically have $\delta^{15} \mathrm{~N}$ values of near $0 \%$ (Heaton, 1987; Kendall, 1998) but the low nitrate concentrations and the small range in $\delta^{15} \mathrm{~N}$ near $0 \%$ observed here make rain water a more likely source. Rain water nitrogen may come in the form of nitrate or ammonium, and would interact with soil nitrogen during infiltration and recharge. The isotopic signature of nitrate for these well water samples is therefore consistent with a rainwater nitrogen source, in which oxygen in nitrate is equilibrated with soil water oxygen (Xue et al., 2009, Kool et al., 2011). 
Other lines of evidence are consistent with a recent rainwater source for groundwater and solutes in the Arroyo Seco area. For example, stable isotopes of the water molecule from samples in the Arroyo Seco area are relatively light (negative) compared to values from the rest of the valley, and all fall on or very near the Global Meteoric Water Line (GMWL; figure 7). The steep terrain of the Arroyo Seco watershed results in rapid runoff of precipitation that forms in nearby peaks of the Sierra de Salinas. Monitoring well $\delta^{18} O$ and $\delta \mathrm{D}$ values and creek values taken at the same time (Table 1d, December sampling) are very nearly the same, suggesting a close connection between surface water and groundwater. The rapid communication between surface water and groundwater is confirmed by calculated apparent groundwater ages of less than one year in the two Arroyo Seco area wells with shallow perforations of less than $80 \mathrm{ft}$ (Table 1a and Table 1c). In addition, water conductivity values measured in Arroyo Seco area samples are low compared to values from other parts of the valley (Table 1a), and only slightly greater in well water than surface water, with only minor addition of solutes during recharge.

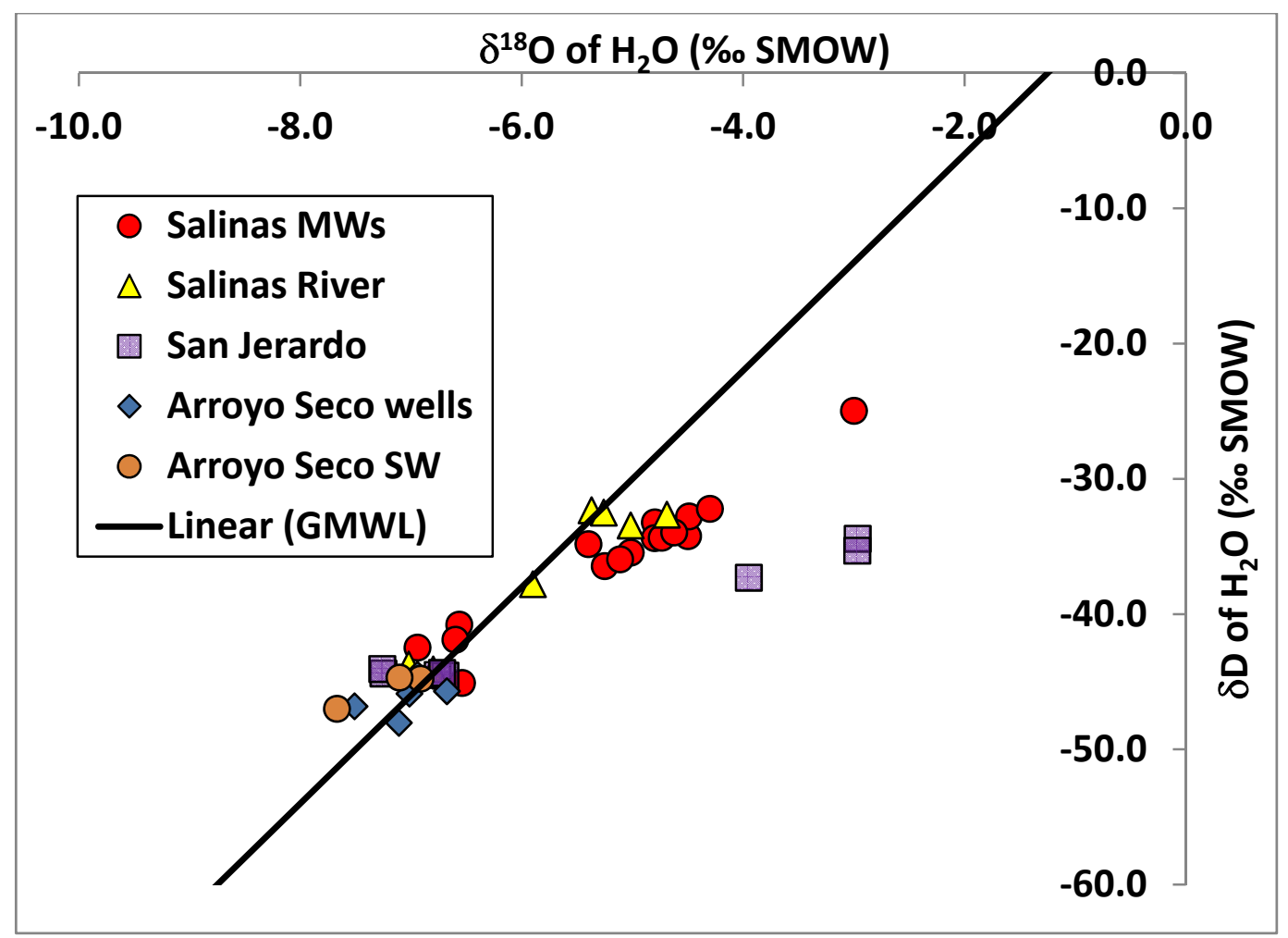

Figure 7. Stable isotopes of the water molecule are plotted along with the global meteoric water line.

Interestingly, at 2.6 to $5.0 \mathrm{pCi} / \mathrm{L}$, the tritium concentrations measured in water from Arroyo Seco Creek are lower than those observed in other samples from the Salinas area, and lower than those observed for surface water or recent recharge in the large statewide GAMA data set (Table 1c). (Tritium concentrations in monitoring wells adjacent to the Arroyo Seco are also lower on average than values observed in Salinas River monitoring wells, but somewhat higher than those observed in Arroyo Seco surface water.) As previously described, the Arroyo Seco watershed is situated in steep Coast Range terrain, with headwaters close to the Pacific Ocean near Morro Bay. The source of moisture for precipitation is the nearby ocean water and water in Arroyo Seco is derived mainly from precipitation in 
its headwaters. The low tritium concentration therefore reflects the low concentration expected for water derived from marine precipitation.

\section{Surface Water-Groundwater Interaction: Monitoring Wells Along the Salinas River}

Transport of water and solutes in areas adjacent to the Salinas River are examined in three ways: 1) physical measurements of groundwater elevation compared to stream elevation and streamflow with time, 2) comparison of geochemical and isotopic constituents measured in Salinas River water over a seasonal hydrograph with the same constituents measured in monitoring wells adjacent to the river, and 3) comparison of geochemical and isotopic constituents analyzed in monitoring wells adjacent to the river with the same constituents measured in public drinking water wells from the Monterey-Salinas GAMA study unit. One of the main goals of this study is to examine whether or not denitrification is occurring between the river and nearby monitoring wells. Nitrate and water mass tracers were examined in order to determine sources of nitrate, assess whether denitrification is an important process, and track the movement of water near the river. Paired monitoring wells, screened at two depth intervals were sampled for the constituents listed in Table 1 at 4 locations along the river (8 individual boreholes; all screened above the 400 Foot aquifer as shown on figures 12 and 13).

Pressure transducers installed and operated by Monterey County Water Resources Agency (MCWRA) in two sets of nested monitoring wells near the river at Chualar and Gonzales show that the river is strongly losing throughout the year in those reaches (figure 8a and 8b). The Salinas River is shallow and the river bed is not significantly incised; also groundwater pumping has lowered the water table leaving the bottom of the river channel at an elevation at least ten feet higher than the highest water table elevation over the period of observation. At the Gonzales location (wells $06 \mathrm{C0} 2$ and 06C01; figure 8a), the recorded pressures in the nested wells show a downward gradient (.022 ft/ft maximum) over the entire water year. At Chualar, a comparison between the well hydrographs and USGS stream gauge data reveals a lag time of about 2 months between peak river flow and the peak in the well hydrographs (figure 9). A consistent, slightly upward gradient (.013 ft/ft maximum) is evident between the two subsurface zones of observation in this part of the basin, where confining conditions begin at a depth between the two nested wells, above the 180 Foot aquifer.

Radon activities measured in surface and groundwater can be used to constrain the contribution of groundwater influx to river discharge. In this study, river water at the Gonzalez and Chualar sites did not contain detectable radon ( $<8-20 \mathrm{pCi} / \mathrm{L})$, consistent with a losing river at these sites. Radon in groundwater collected from nested monitor wells at these sites had detectable and variable radon (ranging from 26 to $455 \mathrm{pCi} / \mathrm{L}$ with an average of $263 \mathrm{pCi} / \mathrm{L}$ ). A simple volume calculation using a river radon activity of $\angle 8 \mathrm{pCi} / \mathrm{L}$ and a groundwater endmember radon activity of $450 \mathrm{pCi} / \mathrm{L}$ constrains the groundwater component in river water at these sites to be less than $2 \%$. Such a calculation, however, assumes no loss of radon to atmosphere and is only applicable to very slowly moving streams at the 
point of groundwater discharge. We used a simple radon evasion model that assumes uniform discharge of groundwater to surface water along the river channel and a radon gas transfer velocity of 1.0 to 4.0 $\mathrm{m} /$ day (for low to high flow conditions, respectively) to provide more realistic upper limits on groundwater discharge to surface water. At the Chualar site, river water samples were collected under high, intermediate and low flow conditions as measured at the USGS gage station at the site. Under low flow conditions (river discharge $=950 \mathrm{~m}^{3} /$ day), groundwater discharge to the river is constrained to be less than $50 \mathrm{~m}^{3} / \mathrm{km} /$ day (accounting for less than $\sim 5 \%$ of total river discharge per kilometer of river channel); while under peak flow conditions $\left(4,000,000 \mathrm{~m}^{3} /\right.$ day), groundwater discharge to the river is constrained to be less than $6,000 \mathrm{~m}^{3} / \mathrm{km} /$ day (accounting for less than $\sim 0.2 \% / \mathrm{km}$ of total river discharge). Given that river radon activity may be significantly lower than $8 \mathrm{pCi} / \mathrm{L}$ (with corresponding lower limits for groundwater discharge), these model results are still consistent with losing river reaches at Chualar and Gonzales. 


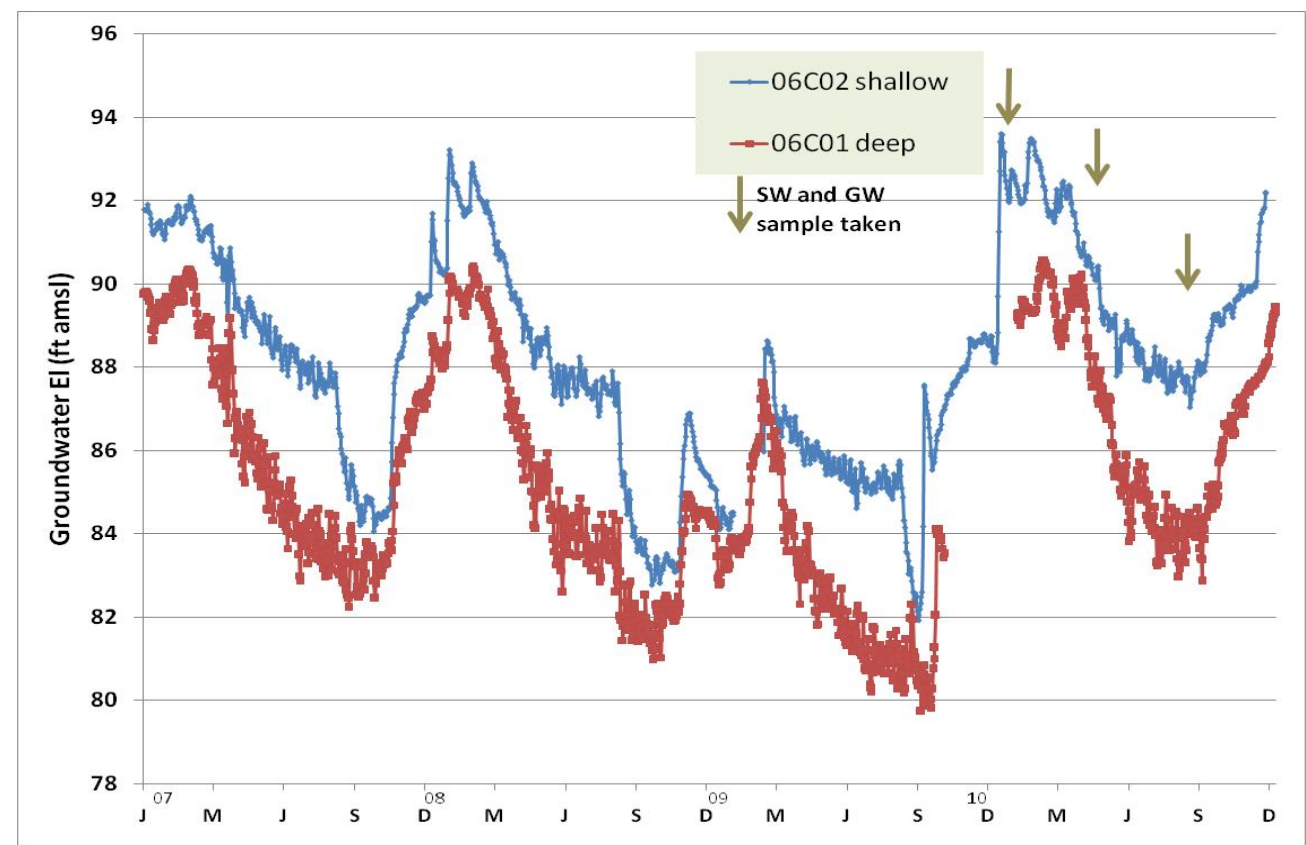

Figure 8a. Groundwater elevations derived from continuous water level measurements from pressure transducers in nested monitor wells adjacent to the Salinas River near Gonzales. Dates on which surface water and groundwater samples were collected are shown with arrows.

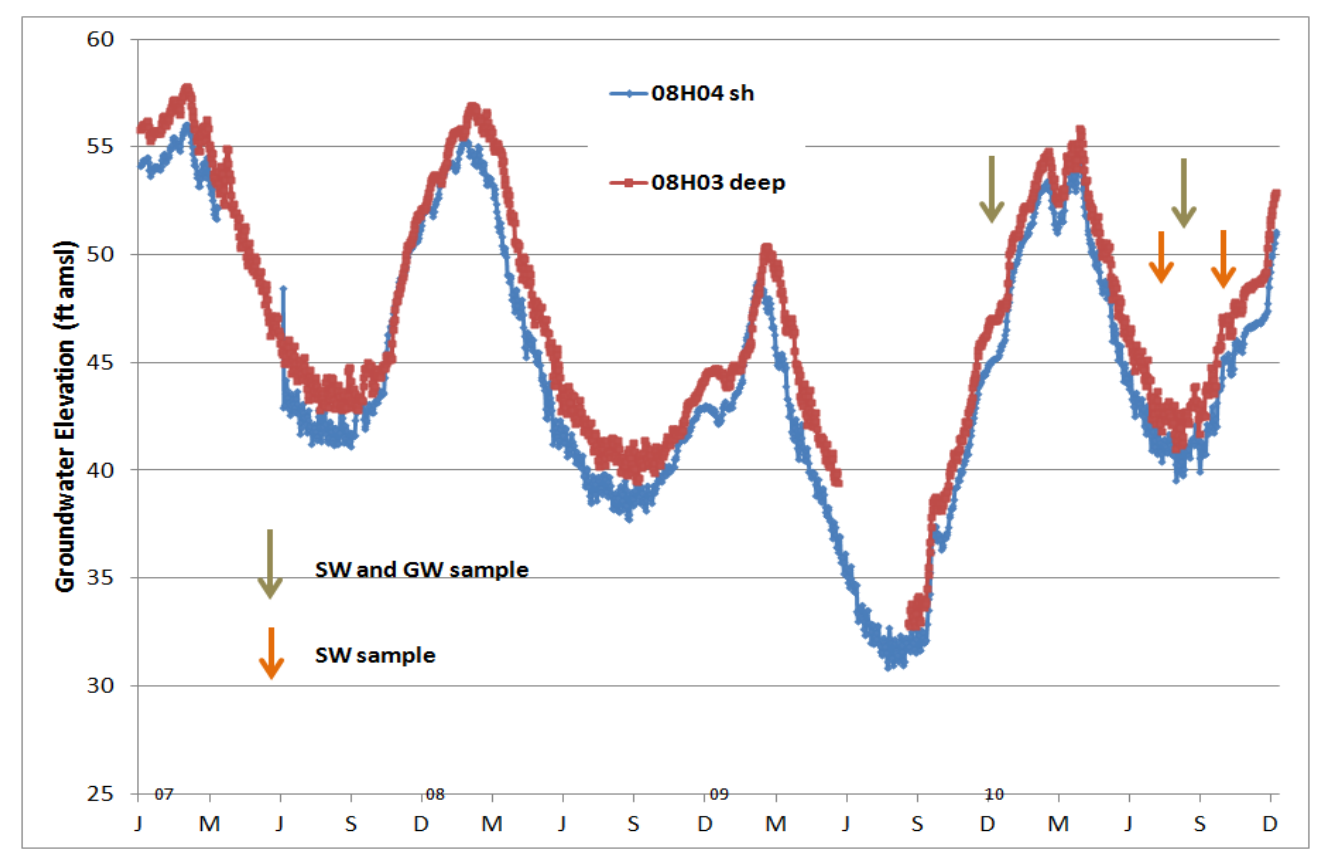

Figure 8b. Groundwater elevations derived from continuous water level measurements from pressure transducers in nested monitor wells adjacent to the Salinas River near Chualar. Dates on which surface water and groundwater samples were collected are shown with arrows. 


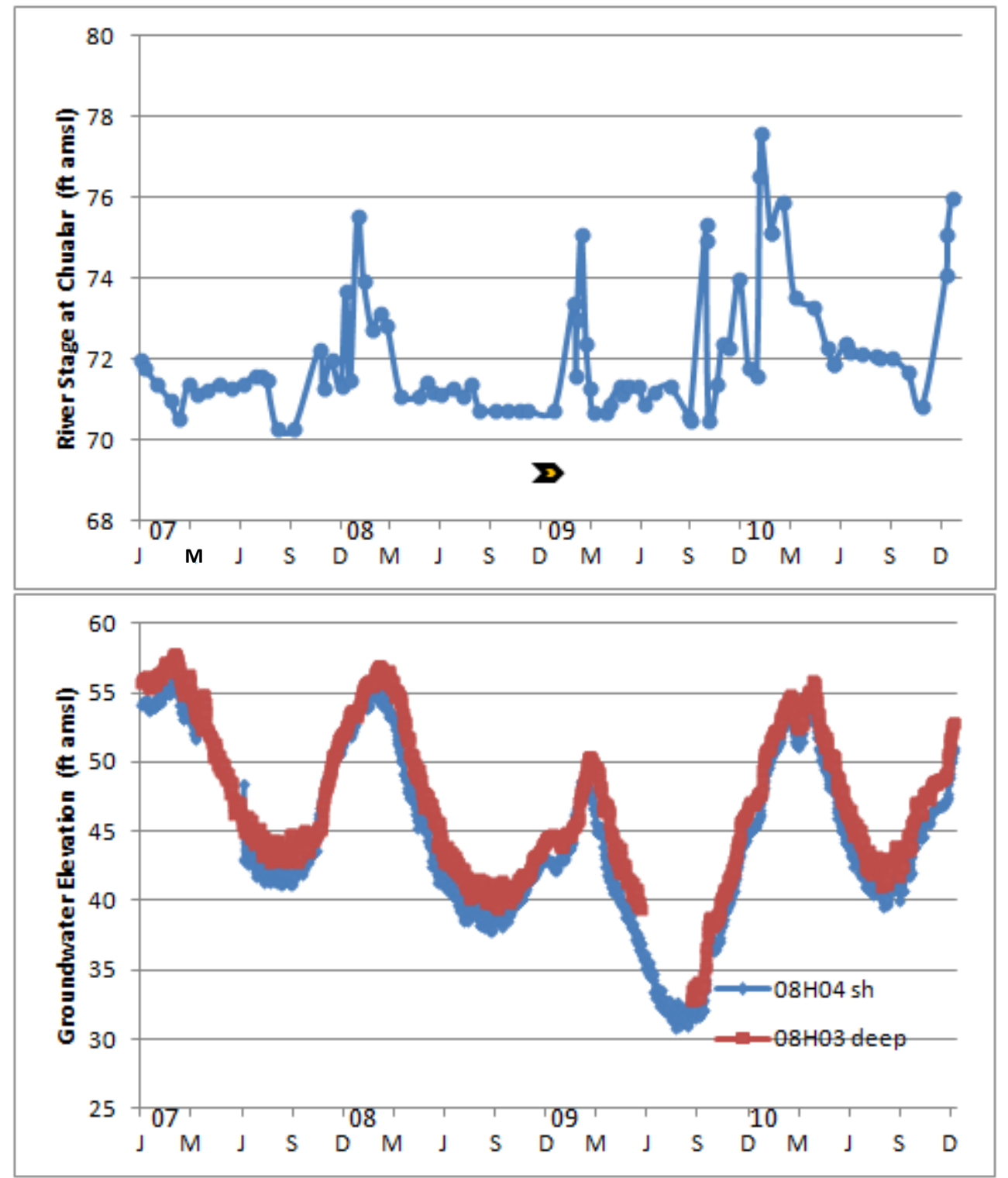

Figure 9. Comparison of river stage measured at Chualar and groundwater elevation in nested wells adjacent to the river. The yellow arrow on the top figure shows the elevation of the channel bottom at Chualar in 2010. 


\section{Salinas River and monitor well chemical and isotopic results}

Results of major anion analysis of surface water grab samples from the Salinas River over the course of the study are shown in figure 10. Also included are results for the same parameters from the USGS database (http://ca.water.usgs.gov/waterdata/) for samples taken in 2010 from the Salinas River at Chualar Bridge. USGS analyses of nitrate, ammonia, nitrite, and organic $\mathrm{N}$ reveal that nitrate is the dominant form of nitrogen in the river throughout the year. Nitrate concentrations ranged from a low value of $0.5 \mathrm{mg} / \mathrm{L}$ on $8 / 20 / 2010$ to a high value of $24.6 \mathrm{mg} / \mathrm{L}$ on 5/19/2010. Nitrate concentrations are correlated with the other major anions, sulfate and chloride, suggesting that these solutes have the same source. There is an inverse correlation between the anion concentrations and flow, suggesting a dilution effect; however higher concentrations are observed throughout the period of runoff (Jan June) and in a pulse of high TDS water that enters the river in the late spring. USGS analyses from 20062010 for this location reveal the same general patterns over the past several years (higher nitrate concentrations during winter-spring runoff, low concentrations during late summer when reservoir releases are the main source of flow).

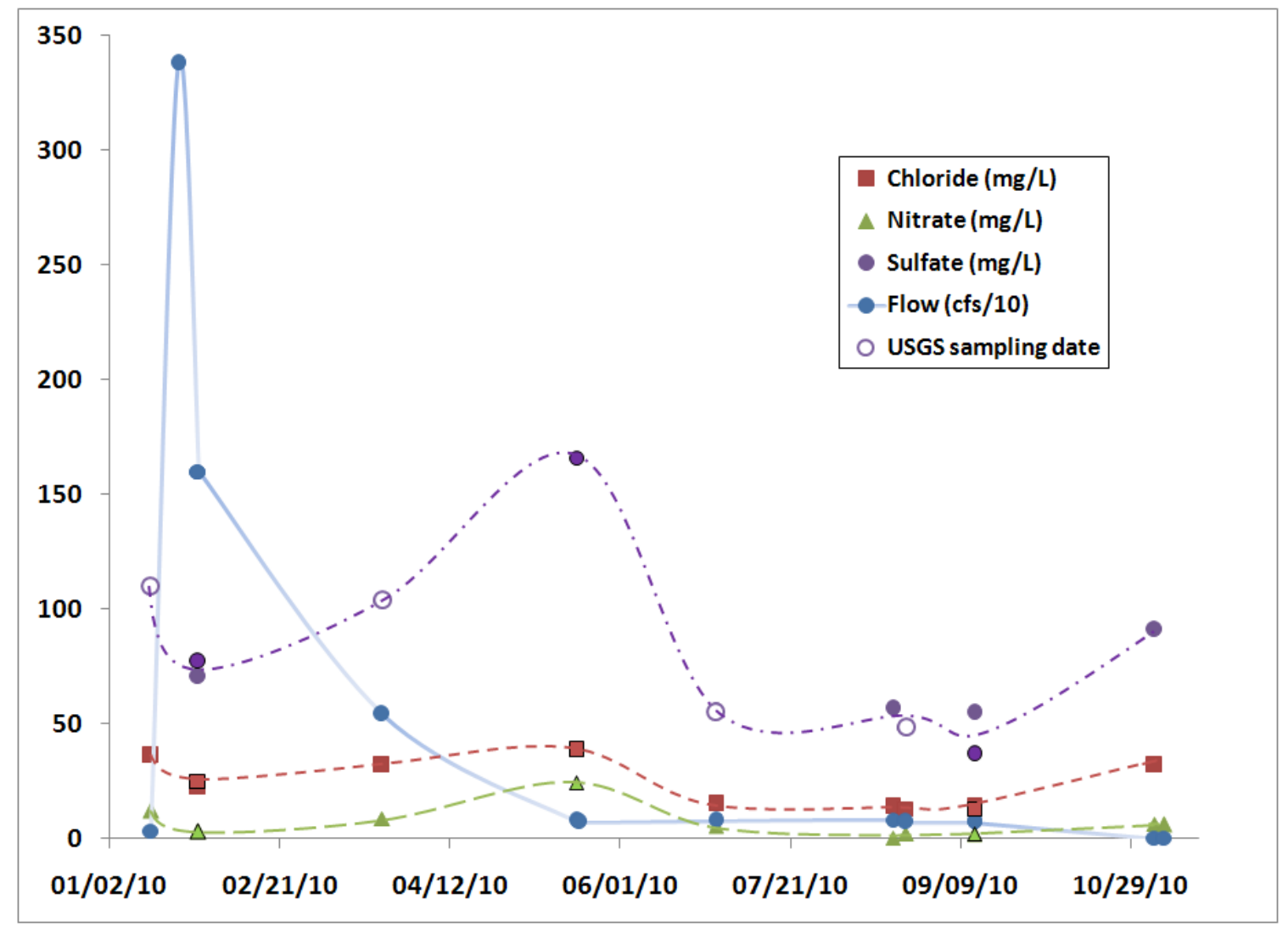

Figure 10. General anion results for Salinas River water samples at Chualar (solid symbols) and Gonzalez (symbols with black outline). Results from both LLNL and USGS sampling are shown, with USGS sample dates indicated by open symbols on the sulfate curve. Flow data are USGS measurements at Chualar. 


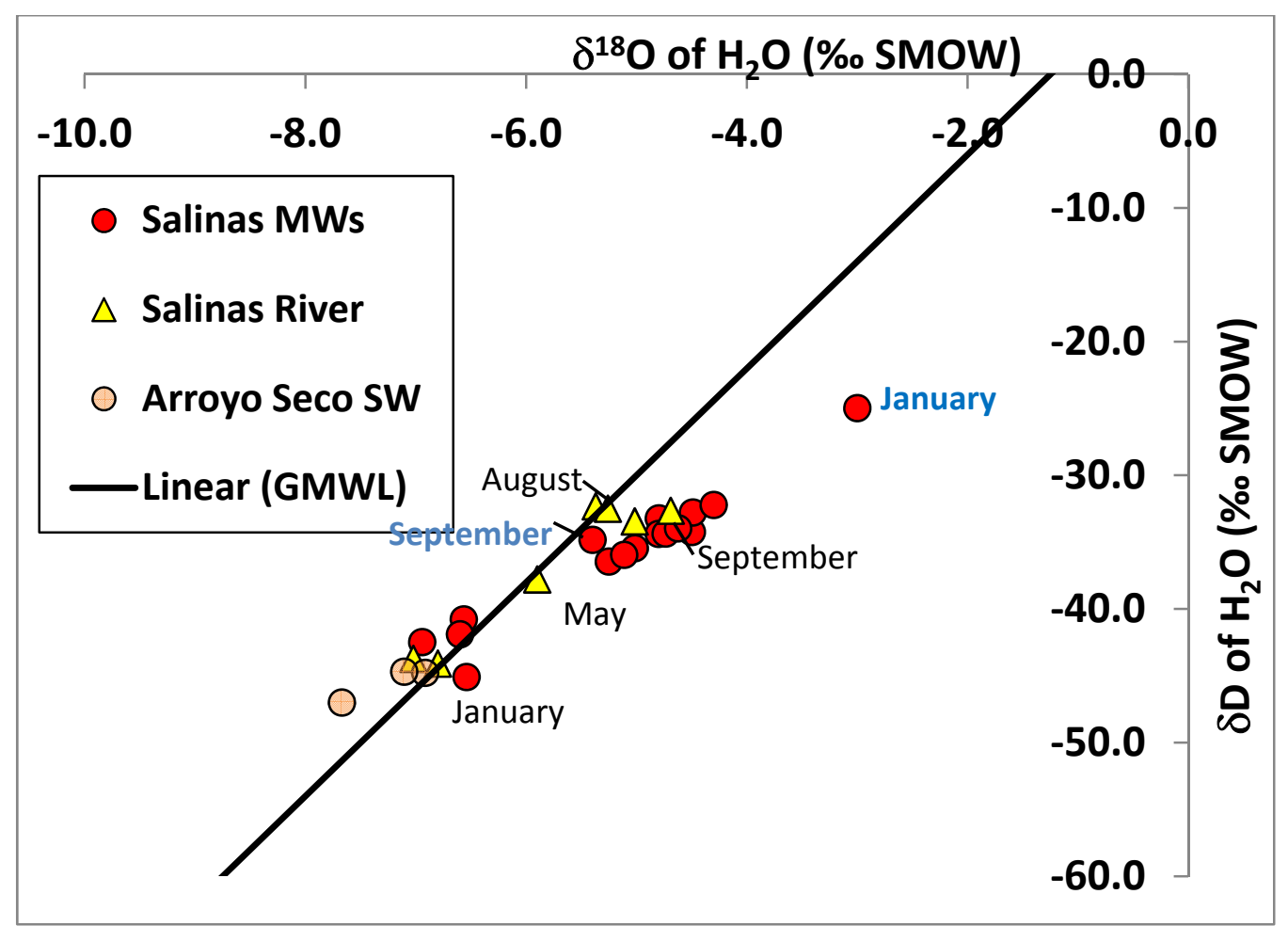

Figure 11. Results of analysis of stable isotopes of the water molecule $\left(\delta^{18} \mathrm{O}\right.$ and $\left.\delta D\right)$ for surface water and monitor well samples (same results as shown on Figure 7). Labels in black text indicate the sampling month for samples from the Salinas River, while blue text labels indicate the sampling month for the shallow well near Gonzales (17S/05E-06C02).

A comparison of stable isotopes between samples from the Salinas River and well water samples reveals information about the source of water in the river over the year, and about the source of water to wells. As shown on figure 11, river water samples go from relatively light $\delta^{18} \mathrm{O}$ values of about $-7 \%$ and falling on the meteoric water line (MWL) in January, to heavier values later in the year, which eventually move off the MWL to an evaporated signature by September. (The Salinas River at Chualar was dry in November, 2010.) Stable isotope values measured in water from the Salinas River at Chualar over the years 1984-1988 (Coplen and Kendall, 2000), show a similar pattern of light values during winter and spring months and heavier values during summer and fall, but overall, the historical patterns are heavier $\left(\delta^{18} \mathrm{O}-2.22 \%\right.$ o to $-5.73 \%$, with a mean $\delta^{18} \mathrm{O}$ of $-3.61 \%$ o $\left.(\mathrm{n}=19)\right)$ and are more frequently evaporated (falling below the global meteoric water line; GMWL) than those observed in 2010. Vengosh et al. (2002) found values of $\delta^{18} \mathrm{O}-4.70 \%$, $\delta \mathrm{D}-35.5 \%$ in September, 1997 for a Salinas River at Gonzales sample, with Lake Nacimiento (the uppermost reservoir) having lighter, non-evaporated values $\left(\delta^{18} \mathrm{O}-6.23 \%\right.$ o and $\delta \mathrm{D}-41.7 \%$ ) and Lake San Antonio (another upstream reservoir) having somewhat heavier, evaporated values ( $\delta^{18} \mathrm{O}-5.42 \%$, $\delta \mathrm{D}-43.0 \%$ ) in July, 1997. Lighter isotopic signatures are expected for winter rains and precipitation from the higher, inland portions of the watershed, while late season rains and valley precipitation are expected to be somewhat heavier. Isotopic signatures showing the effects of evaporation are expected for water from the reservoirs that feed the Salinas River through the summer and fall, and especially for agricultural drainage water. Changes in water management practices aimed 
at preventing agricultural drainage water from entering the river may be the reason that lighter, less evaporated values are observed in more recent years.

Monitoring well samples fall within the range observed for river water over the years but most are relatively heavy and somewhat evaporated (with a slope of 5, typical for an evaporation trend, intersecting the GMWL at $\delta^{18} \mathrm{O}$ of $-6.5 \%$; figure 11$)$. The four samples from the Soledad monitor wells are clustered with the group of winter river and Arroyo Seco samples, showing the influence of precipitation and river water from the upper portion of the watershed. The shallow well nearest the river at Gonzales (17S/05E-06C02) has relatively light values falling near the MWL when sampled in September but very heavy values indicative of evaporation when sampled in January. Given the pattern observed in river water samples, this well produces water that recharged via the river about 3 months prior to sampling, in agreement with the apparent groundwater age of $<1$ year, and with the observed lag between the river and well hydrographs. The other monitor wells, with older apparent ages, integrate longer flowpaths and likely produce a portion of water not recharged via the river. Their stable isotope signatures suggest that late season river recharge and possibly some irrigation return flow are the main contributors to recharging the aquifers in which they are screened.

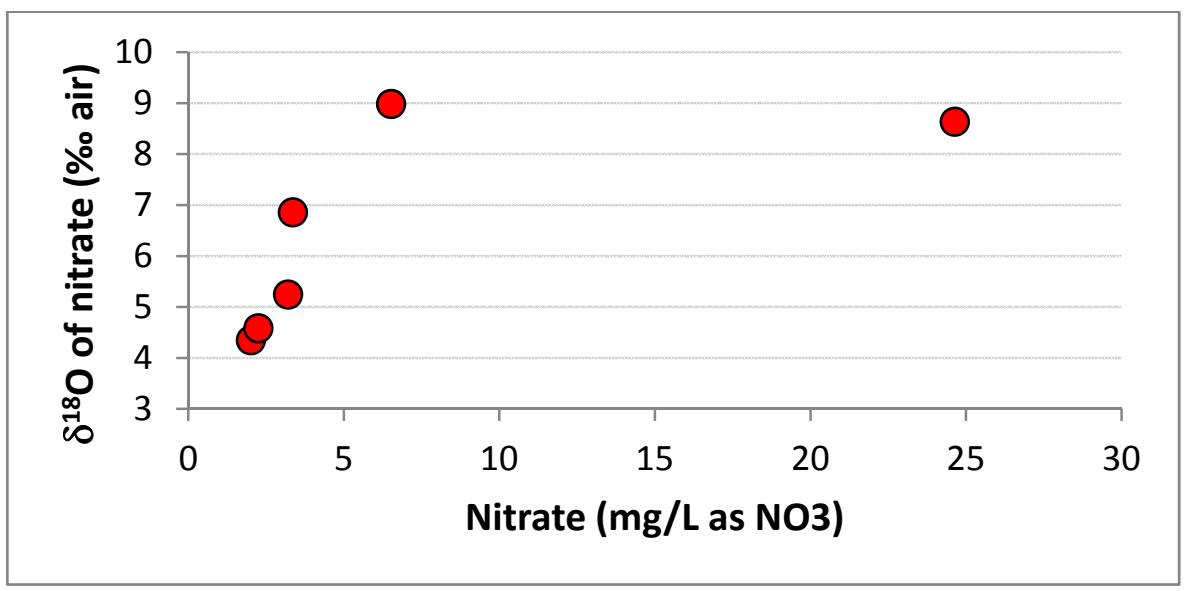

Figure 12. Nitrate concentrations and $\delta^{18} \mathrm{O}-\mathrm{NO}_{3}$ for Salinas River samples collected by LLNL.

Six out of 12 of the measured river nitrate concentrations are higher than $5 \mathrm{mg} / \mathrm{L}$ and likely have a contribution of non-natural nitrate. The isotopic results for nitrate in the Salinas River samples show a tight grouping in $\delta^{15} \mathrm{~N}$, centered at $+7.8 \%$ o (figure 6 ), somewhat higher than the range expected for synthetic anhydrous fertilizer, and in the range expected for nitrate fertilizer, natural soil $\mathrm{N}$, or animal waste (see discussion of the effect of denitrification in the next section). A combination of natural and non-natural land application sources is expected during high runoff periods. Wastewater treatment plant discharges into the river from upstream plants at King City, Greenfield, and Soledad are possible sources of animal waste nitrogen. As shown on figure 12, higher $\delta^{18} \mathrm{O}$ values are associated with higher nitrate concentrations, possibly indicating a larger component of a nitrate fertilizer source, which typically has high $\delta^{18} \mathrm{O}$ values. The range in nitrate concentrations observed in Salinas River samples is similar to, but somewhat lower than the range observed in the Pajaro River in the adjacent watershed 
(Ruehl et al., 2007). Trends in isotopes of nitrate from transects along the Pajaro River revealed the importance of streambed denitrification in decreasing downstream nitrate concentrations in the Pajaro River, which may also occur in the Salinas River. A synoptic transect of river water samples, along with streambed porewater sampling, would be required to demonstrate denitrification within the surface water-shallow subsurface system of the Salinas River.

Examination of groundwater ages, nitrate concentrations, and nitrate isotopic composition in the nested monitor wells at three locations adjacent to the river reveals the fate of nitrate in recharging river and mixing of nitrate applied at the land surface. Groundwater ages, determined from tritium concentrations and dissolved noble gas results, are shown for monitor wells on figure 13. Tritium concentrations exhibit a narrow range, are close to values observed in river water, and are low in comparison to concentrations observed in recently recharged groundwater in other California groundwater basins (e.g., Moran et al., 2002; Moran et al., 2004b). Vengosh et al. (2002) suggest that low tritium concentrations in shallow groundwater from the Salinas Valley are due to widespread mixing between low tritium irrigation return water (that originated as deep groundwater) and precipitation/river recharge. (This idea is discussed in greater detail below, in relation to the San Jerardo well.) Because of the agreement between river water and shallow groundwater values, we attribute the generally low tritium concentrations in Salinas Valley surface waters and shallow young groundwaters to the unimpeded transport of marine-influenced rainwater into the Salinas Valley.

Apparent groundwater ages increase with depth at all locations, but there are differences in the age patterns at wells near Soledad, Gonzales, and Chualar (figure 13). At Gonzales, two sets of nested wells, one approximately $100 \mathrm{ft}$ from the river (06C01 and 06C02) and the other approximately $600 \mathrm{ft}$ from the river (31P01 and 31P02; at the edge of a cultivated field) were sampled, providing information about both vertical and lateral transport near the river. Groundwater ages and related measurements reveal rapid recharge from the river to the groundwater drawn into the shallow well near the river (06C02) at this location, and slower vertical transport to the deeper zone where an age of 12 years is calculated for both of the deeper monitor wells, screened appx. 250-290 ft bgs (figure 13 and Table 1c). An older age (6 yrs) is observed in the shallow monitoring well away from the river (31P02) in comparison to the shallow monitoring well just adjacent to the river $(<1 \mathrm{yr})$. Higher TDS and higher excess air concentrations suggest that the shallow well away from the river (31P02) is recharged (at least in part) by irrigation return water that has moved through a developed vadose zone, while the deeper well at the same location receives water recharged directly from the river. 


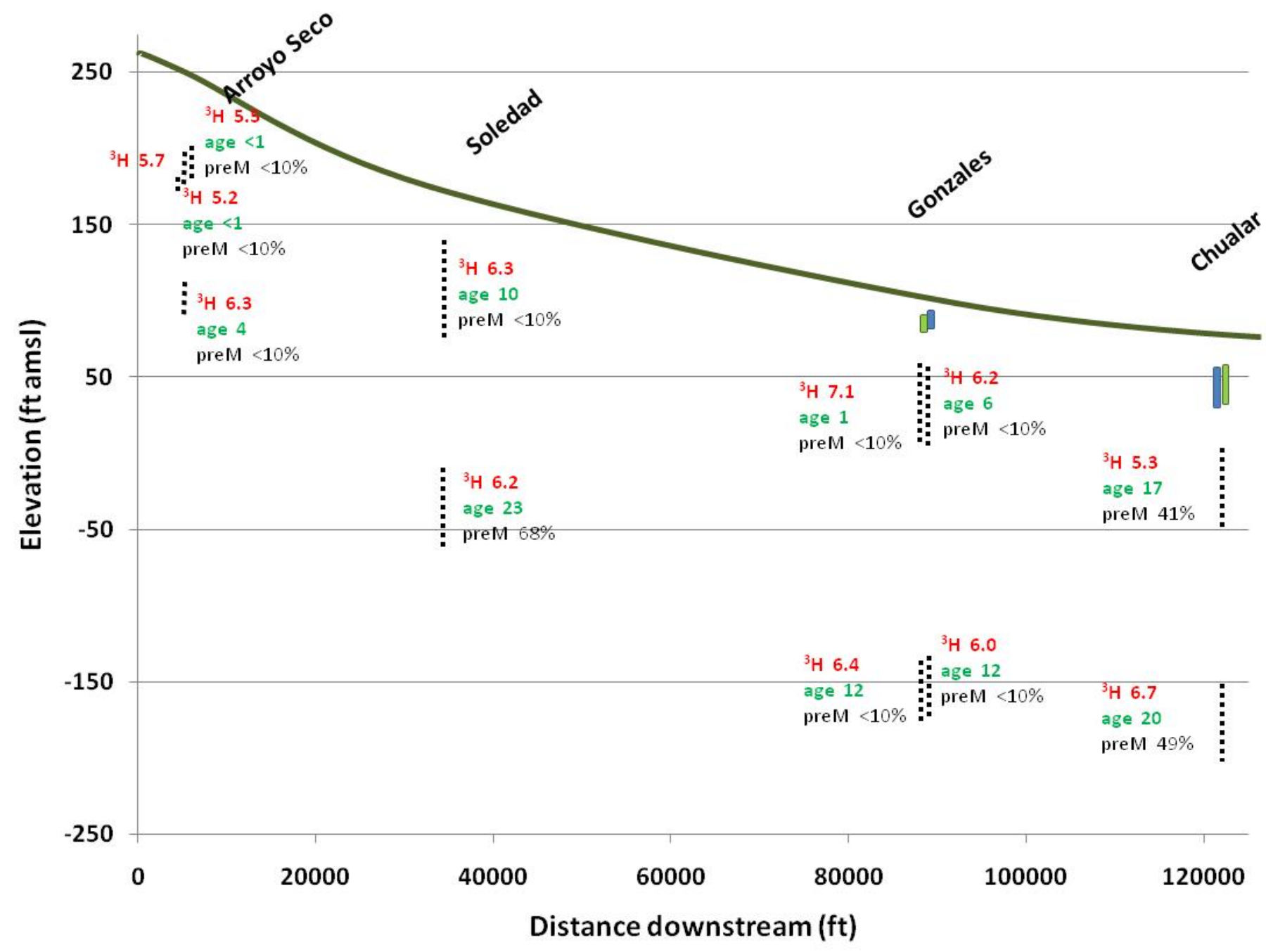

Figure 13. Schematic drawing showing monitoring wells (upstream locations on left to downstream locations on right) with screened intervals (dashed vertical lines) and data derived from noble gas and tritium results. Green and blue shaded rectangles at the Gonzales and Chualar locations show the range in observed water levels for 2010 at deep (green) and shallow (blue) paired monitoring wells (shown on figures $10 a$ and 10b). 
Somewhat older ages of 13-26 years are observed (over two sampling events in January and September 2010 ) in both the shallow and deep wells at the downstream location, near Chualar $(8 \mathrm{H} 2 \mathrm{~A}, 8 \mathrm{H} 2 \mathrm{~B})$, where the basin becomes confined and where transport of river water to nearby wells is significantly slower than near Gonzales. The calculated ages at the shallow and deep wells do not differ by much, and the well logs indicate that the blue-gray clay layer that typifies the confining unit is found at a depth of 60-82 ft bgs, above the well screens. Somewhat older ages are also observed at the monitoring wells near Soledad (33R01, 33R02), which are located $730 \mathrm{ft}$ from the river. The samples from the Soledad wells are characterized by very high TDS, nitrate, and sulfate concentrations. The area in which the wells are situated has been identified previously as an area of high-salinity, high-sulfate groundwater that has evolved by water-rock interaction and weathering of marine gypsum and carbonate rocks of the Miocene Monterey formation (Vengosh et al., 2002). However, high TDS, high nitrate and relatively young groundwater (mean apparent ages of 10 to 23 years) indicate that this area is likely recharged by irrigation return, where the irrigation water source is high TDS groundwater (recycled groundwater affected by the marine formation) and nitrate is leached from the soil zone.

If simple piston flow is assumed, an estimate of the vertical recharge rate can be calculated from the groundwater ages measured in these monitor wells. Vertical flow rates in the saturated zone, determined from distances from the water table to the midpoint of the perforated interval and apparent groundwater ages, range from 4-20 ft/yr at Chualar to 18-85 ft/yr at Gonzales. These rates are higher than those estimated by Darcy's Law (using a porosity of $25 \%$ and a hydraulic conductivity of 500 $\mathrm{ft} / \mathrm{d}$ the calculated vertical velocity is $<1 \mathrm{ft} / \mathrm{yr}$ at Gonzales), but recharge is likely episodic, and older ages in deeper wells likely reflect longer transport pathways from sources other than the river. Transit time through the vadose zone must also be considered. Burow et al. (1993) give estimates of travel times through the vadose zone in the Salinas area on the order of 10 to 20 years for a vadose thickness of 80 to $120 \mathrm{ft}$, but the vadose zone is only about $30 \mathrm{ft}$ thick near the monitoring wells so a shorter travel time is expected.

Low nitrate concentrations are found in the monitoring wells adjacent to the river, except at the Soledad location. On average, the monitor wells samples (excluding Soledad; $n=13$ ) have a lower nitrate concentration $(1.9 \mathrm{mg} / \mathrm{L})$ than the Salinas River samples $(6.2 \mathrm{mg} / \mathrm{L}$; including USGS results from the Salinas River at Chualar in 2010 and results from this study; $\mathrm{n}=10$ ). Furthermore, molar ratios of $\left[\mathrm{NO}_{3}{ }^{-}\right.$ ]$/\left[\mathrm{Cl}^{-}\right]$are, on average, lower in groundwater samples (.057) than in Salinas River samples (.072), suggesting that nitrate is removed relative to non-reactive chloride. Samples from the shallow monitor wells near Gonzales had nitrate concentrations too low for determination of the nitrate isotopic composition. All other monitor well samples show evidence for denitrification, either by isotopic compositions that are enriched in ${ }^{15} \mathrm{~N}$ and ${ }^{18} \mathrm{O}$ (falling along a slope of approximately $1 / 2$ on figure 6 ), or by the presence of excess nitrogen (figure 5). Low dissolved oxygen concentrations and total organic carbon concentrations of 2-3 mg/L (Table 1d) provide the necessary geochemical conditions for denitrification. The isotope ratios in the samples from the Gonzales and Chualar wells have therefore all been shifted by denitrification, so the original nitrate source signature is not preserved. The ratios are less affected in the Soledad wells because of very high residual nitrate concentrations. 
Excess nitrogen accumulates in groundwater during saturated zone denitrification - denitrification that takes place in the unsaturated zone (or e.g., in saturated pores of the streambed, followed by downward transport through an unsaturated zone) causes a shift in the isotopic signature in residual nitrate but excess nitrogen is lost to the gas phase. The excess nitrogen observed in monitor well samples therefore likely represents only a fraction of the denitrification that has taken place, given that the river channel is at least several feet above the water table throughout the year. Loss of nitrogen from denitrification in irrigation return flow would also take place during transport through the vadose zone. An estimate of the minimum denitrified fraction can thus be calculated using the measured excess $\mathrm{N}_{2}$ (expressed as $\mathrm{NO}_{3}{ }^{-}$) and the nitrate remaining:

$$
\left.\frac{[x s \mathrm{N2} \text { as NO3- }]}{[x s \mathrm{N2} \text { as } \mathrm{NO3-}]+\left[\text { residual } \mathrm{NO3}^{-}\right]} \times 100=\% \text { denitrified (Equation } 1\right)
$$

In this formulation, samples from Chualar wells are $62-91 \%$ denitrified, while Soledad well samples are only $7-12 \%$ denitrified. Incomplete denitrification may be the result of exhaustion of the electron donor (likely organic carbon) or a change from low oxygen to oxygenated conditions. More likely is that these samples are mixtures of denitrified groundwater and ambient groundwater recharged through irrigation return, which may be less likely to have undergone widespread denitrification because episodic recharge allows entrainment of dissolved oxygen. The amount of excess nitrogen in monitoring wells is at the upper end of the range of nitrate found in the Salinas River. Although it is possible that all of the excess nitrogen is from nitrate recharged via river water, it is more likely that there is an additional contribution of nitrate from surrounding areas, especially in the deeper monitoring wells. 


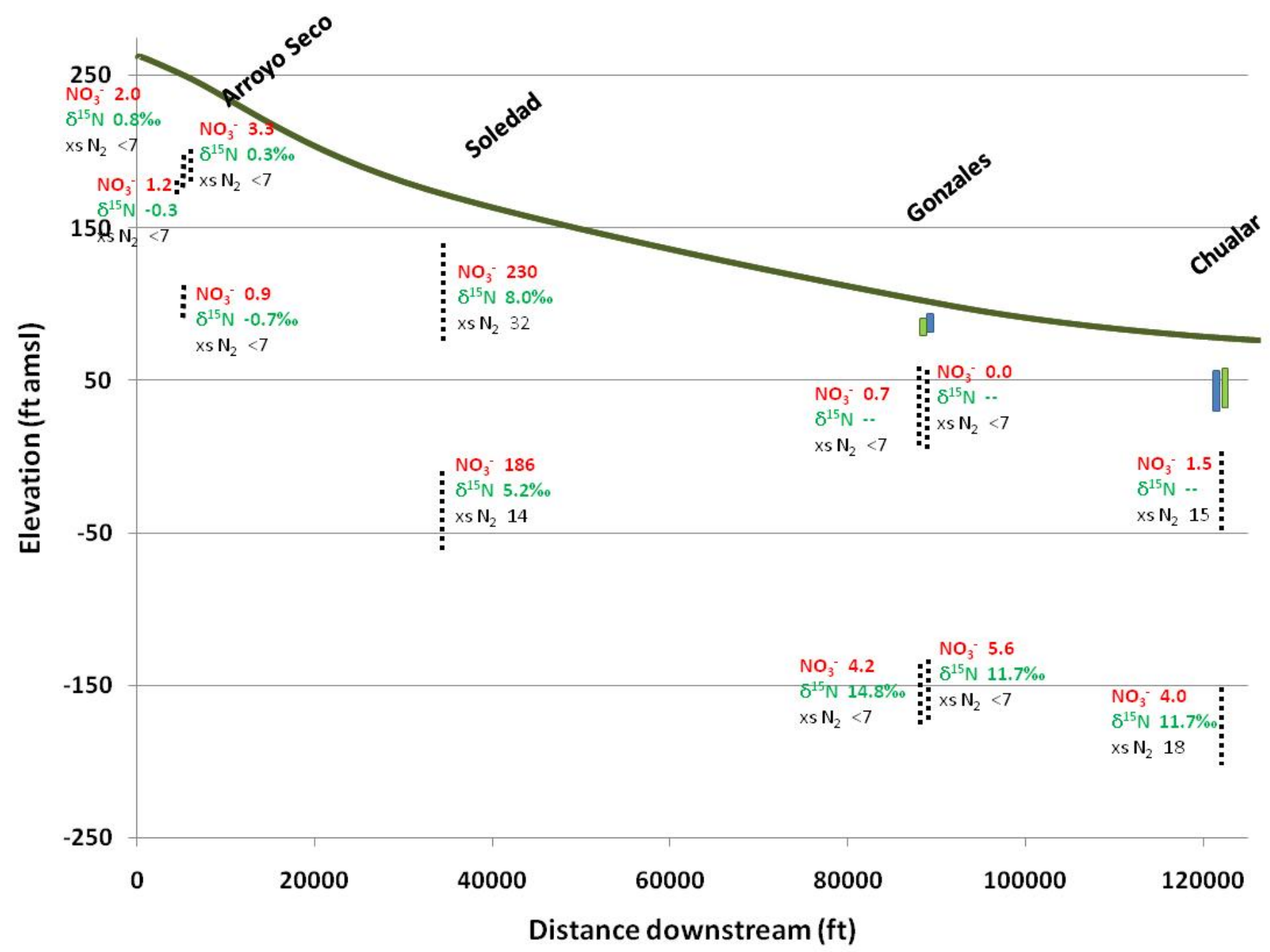

Figure 14. Schematic drawing showing monitoring wells (upstream locations on left to downstream locations on right) with screened intervals (dashed vertical lines) and nitrate concentration(in $\mathrm{mg} / \mathrm{L}$ ), $\delta^{15} \mathrm{~N}$, and excess nitrogen concentrations (converted to $\mathrm{mg} / \mathrm{L}$ as $\mathrm{NO} 3$ ). 
In a closed system, denitrification leads to a decrease in the nitrate concentration, an increase in excess nitrogen, and a Rayleigh-type fractionation of $\mathrm{N}$ and $\mathrm{O}$ isotopes in the residual nitrate. In that case, the isotopic composition of residual nitrate depends on the initial isotopic ratio, the fraction of nitrate remaining $\left(\mathrm{f}=\mathrm{C} / \mathrm{C}_{\text {initial }}\right)$, and the fractionation factor for denitrification $(\alpha$, where $\alpha=$ Ratio $_{\text {product }} /$ Ratio $_{\text {reactant }}$ ):

$$
\delta^{15} N=\left(1000+\delta^{15} N_{\text {initial }}\right) f^{(\alpha-1)}-1000 \quad \text { (Equation 2) }
$$

${ }^{15} \mathrm{~N} /{ }^{14} \mathrm{~N}$ and ${ }^{18} \mathrm{O} /{ }^{16} \mathrm{O}$ ratios exhibit varying degrees of enrichment according to the how selective the denitrifying bacteria are during denitrification. Enrichment factors ( $\varepsilon$; approximated as 1000 In $\alpha$ in \%o units) of between $-40 \%$ and $-5 \%$ o have been reported for denitrification (Kendall, 1998, Hubner, 1986). In river systems, observed enrichment factors are on the lower end of the range. Sebilo et al. (2003) observe $\varepsilon$ of $-18 \%$, while Ruehl et al. (2007) found a lower range ( $\varepsilon-6 \%$ o to $-9 \%$ ) at low flow in the Pajaro River compared to enrichment factors observed at high flow ( $\varepsilon-17 \%$ o to $-20 \%$ ). Greater enrichment factors ( $\varepsilon$ up to $-57 \%$ ) were observed in the saturated zone at dairy sites (Singleton et al., 2007), where microbes can be selective and denitrification efficiency is low, even though most nitrate is denitrified. In Salinas monitor well samples, initial $\delta^{15} \mathrm{~N}$ values can be estimated from equation 2 using measured $\delta^{15} \mathrm{~N}$ values for residual nitrate (Table $1 \mathrm{~b}$ ), assumed $\varepsilon$ values based on previous studies, and the degree of denitrification calculated from measured nitrogen and nitrate. For well 16S/04E-08H04 (shallow well at Chualar), using an assumed $\varepsilon$ value of $-5 \%$ (for a streambed system) and $f=0.38$ (Table 1b), the result is a $\delta^{15} \mathrm{~N}_{\text {initial }}$ of 3.4\%o. For well 17S/05E-33R02 (shallow well at Soledad), using an assumed $\varepsilon$ value of $-30 \%$ (groundwater system) and $f=0.88$ (Table $1 \mathrm{~b}$ ), the result is a $\delta^{15} \mathrm{~N}_{\text {initial }}$ of $4.2 \%$. For river water samples, whose measured $\delta^{15} \mathrm{~N}$ values average $7.8 \%$, a low enrichment similar to the value used for Chualar would bring initial values into a similar range of 3-5\%, which also matches the range observed in the highly contaminated (but not denitrified) San Jerardo groundwater. It is likely, therefore, that the nitrate found in the Salinas River and in monitor wells had an original source signature in the range expected for inorganic fertilizer. 


\section{Regional Transport: Integrating Additional GAMA Results}

Looked at on a regional scale, groundwater ages can be used to identify recharge areas and to examine bulk groundwater flow direction and flow rate. In addition, groundwater ages offer a method of assessing contamination vulnerability by identifying areas where surface contaminants may reach deeper aquifers accessed by public drinking water supply wells over decadal (or less) time periods (e.g., Moran et al., 2002). In the Salinas Valley, comparing groundwater ages gathered under the GAMA Priority Basin Project and ages measured in wells along the river is useful for delineating the area of influence of direct river recharge. Complications arise because wells are screened over differing intervals and because of transient effects due to pumping and recharge. Kulongoski and Belitz (2011) found that groundwater ages generally increased with increasing well depth and with increasing depth to top perforations. Also, water in most wells with their entire perforated interval greater than $200 \mathrm{ft}$ bgs was pre-modern, defined as water that entered the aquifer system more than 50 years ago, which roughly corresponds with water below the detection limit for tritium.

In general, a pattern of decreasing groundwater age from the Upper and Forebay subbasins to the 180 Foot/400 Foot subbasin ("Pressure Area") is discernible on figure 15. This is expected since groundwater flow roughly mirrors topography and river flow. With only a few exceptions, the wells northwest of Chualar, which are screened below the upper confining unit, have very low or non-detectable tritium concentrations, and apparent groundwater ages greater than $55 \mathrm{yrs}$. Uniformly young groundwater is found in wells in the Arroyo Seco Cone, confirming that it is an area of active recharge. Similarly, wells in the portion of the study area upstream of Soledad, in the Forebay and Upper subbasins, all contain tritium and exhibit relatively young ages.

Wells immediately adjacent to the Salinas River exhibit relatively young ages, especially near Gonzales, as described above, but given the limitations of the sample set, the lateral extent of the influence of river recharge can only be assessed qualitatively. Near Gonzales, shallow groundwater just $600 \mathrm{ft}$ from the river has an apparent age of 6 years and a GAMA priority basin well in Gonzales (appx. $9300 \mathrm{ft}$ from the river) has an apparent age of 32 years, revealing the decreasing influence of recent river recharge. Deep wells within $3400 \mathrm{ft}$ and $4100 \mathrm{ft}$ of the river near Soledad and Chualar, respectively, are tritiumdead, suggesting that recent recharge from the river is not transported to the deep aquifer along those reaches. Production wells near the river may capture much of the river recharge before it migrates a great distance from the river. GAMA studies using the same isotopic tracers in Sacramento (Moran et al., 2004a) and Chico (Moran et al., 2005a) found the influence of recharge from perennial rivers extended at least 12,000 ft away from the American River laterally into the groundwater basin in Sacramento and $11,000 \mathrm{ft}$ from Big Chico Creek in Chico, even in deep drinking water wells.

Of the 43 GAMA Priority Basin production wells shown on figure 1, 18 have tritium concentrations $<1$ $\mathrm{pCi} / \mathrm{L}$ and another 12 have concentrations between 1 and $3 \mathrm{pCi} / \mathrm{L}$ which, under natural recharge 
conditions, would indicate that a large fraction of the water has a subsurface residence time of more than 50 years. In settings where groundwater is a significant source of irrigation and irrigation is a significant source of recharge, however, shallow groundwaters may have low tritium activity that does not result from a long residence time in the saturated zone, but rather reflects recent recharge from irrigation with old groundwater. If irrigation water is recharged soon after application, the water does not have time to re-equilibrate within the atmospheric/precipitation reservoir, and low-tritium water makes its way into the subsurface. The process may be prevalent because precipitation and irrigation seasons are offset in the Salinas Valley and because vertical recharge is rapid in cultivated fields with sandy soils. Tritium, in the aqueous phase, comes into equilibrium slowly with the surface reservoir while helium, in the gas phase, re-equilibrates quickly. Rapid recycling of old water is therefore recognized by having very low or non-detect tritium concentrations, with ${ }^{3} \mathrm{He} /{ }^{4} \mathrm{He}$ ratios that are close to atmospheric values. However, the long screened wells that make up the GAMA priority basin sample set almost invariably draw in mixtures of old water from deep portions of the aquifer system, and more recent recharge from shallow zones. Such mixtures are difficult to unravel without supporting information from depth-discrete samples or nearby nested monitor wells. 


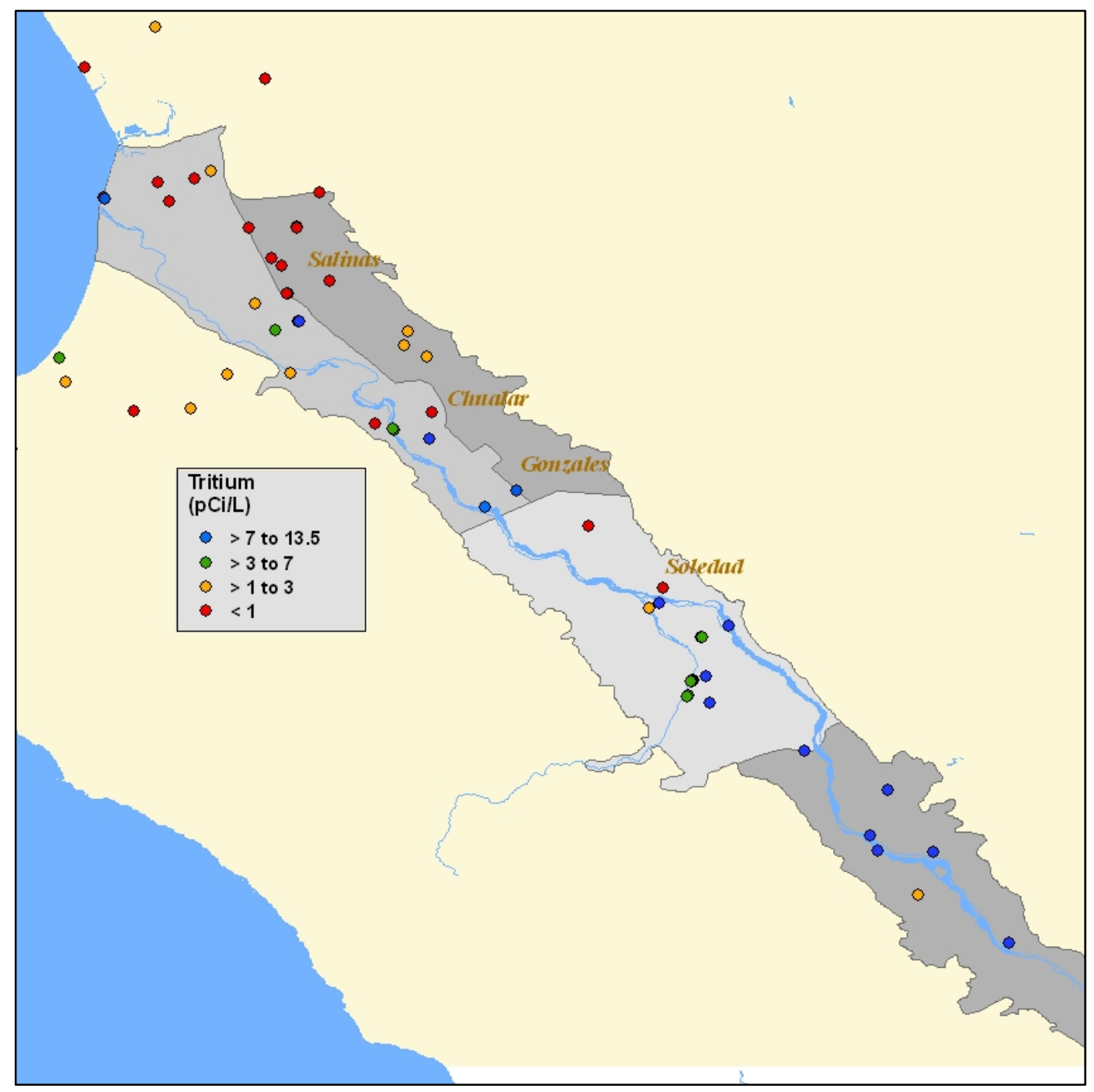

Figure 15. Tritium concentrations in wells from this study and in GAMA priority basin wells. 


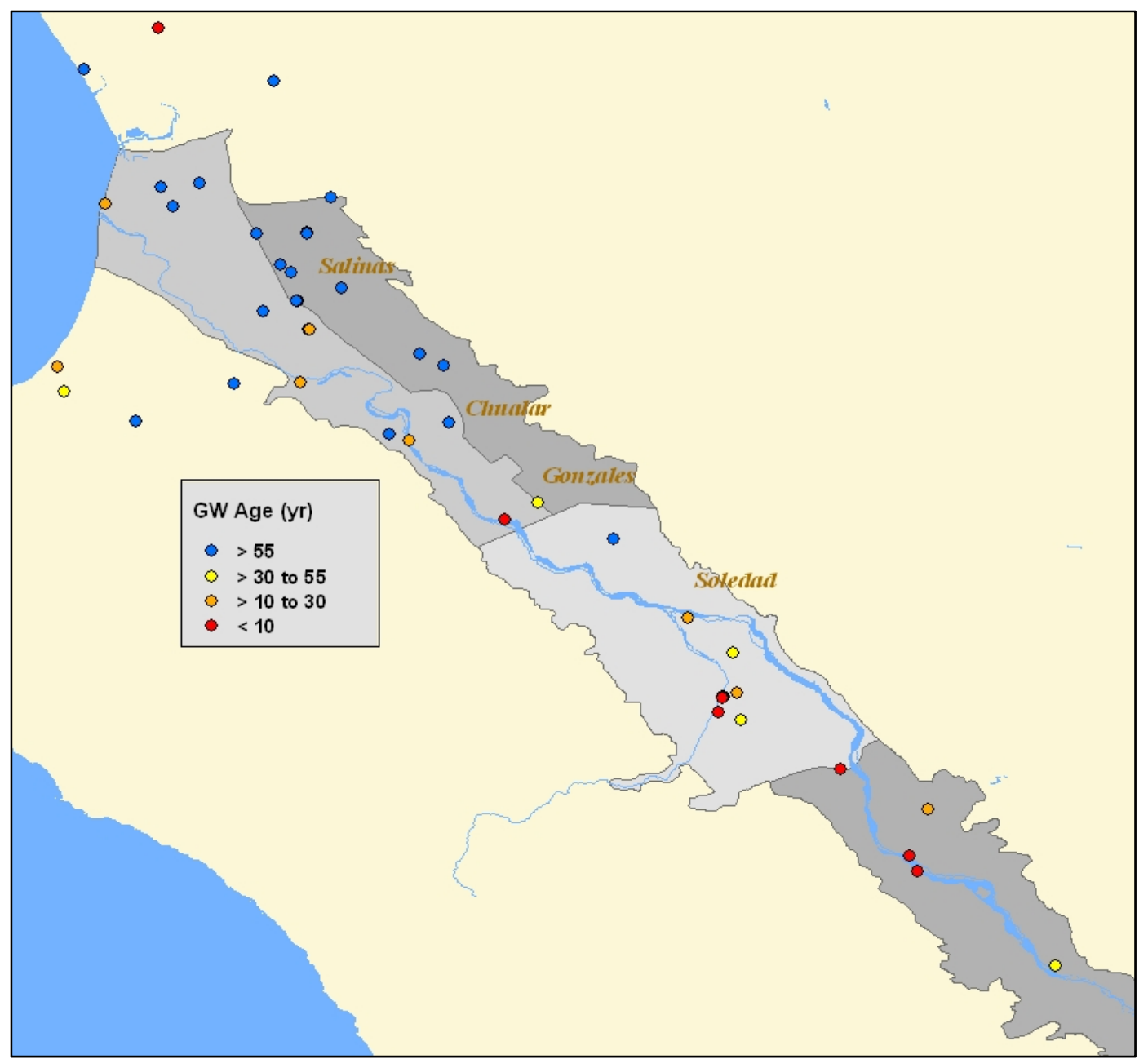

Figure 16. Mean apparent groundwater ages calculated from tritium and dissolved noble gas results for wells from this study and GAMA priority basin wells. (Well types as shown on figure 1.)

The modeled groundwater ages in Salinas Valley wells reported by Fogg et al. (1999) can be compared with the ages shown on figure 16. Fogg et al. use a stochastic-geostatistical framework to incorporate aquifer heterogeneity in transport simulations that use particle tracking, and display the percentage of water that traveled from the water table to each well within e.g., 30 or 50 years. Wells not receiving water within 50 years in the model should coincide with wells that are tritium-dead. Wells with a percentage of younger water should contain tritium, and a corresponding fraction of pre-modern water. In general, the model results and observations are in qualitative agreement. Most wells in the Pressure area have model ages greater than 50 years and are observed to be tritium-dead, with isolated occurrences of wells with a small fraction of young water (low tritium concentrations with a large fraction pre-modern water, as observed). Southeast of the Chualar area, the model shows wells with larger fractions of modern water, as observed. Perhaps most significantly, the model and observations 
both highlight the significance of subsurface heterogeneity and transient flow due to pumping in creating pockets of young and old water.

Fogg et al. (1999) conclude that susceptibility to nitrate contamination in the Salinas Valley is controlled by the complex hydrostratigraphy of basin sediments. In the Forebay and East Side subbasins especially, high nitrate concentrations are found in a few wells with top perforations deeper than $240 \mathrm{ft}$ bgs (MSSV05, MSMB-44, MSMB-02, San Jerardo well; figure 4), indicating the presence of pathways for contaminants to the deep subsurface. The introduction of nitrate to this groundwater is likely taking place via preferential flow along a vertical pathway. Tritium and groundwater age results support this notion, in that wells containing tritium are found in close proximity to tritium dead wells, even though the wells are screened over similar intervals. Furthermore, examination of the extensive GAMA data set reveals that high nitrate concentrations are observed infrequently in wells with low tritium. For example, of 357 GAMA wells from priority basins with tritium concentrations $<2 \mathrm{pCi} / \mathrm{L}$, and USGSmeasured nitrate concentrations, only $4(1.1 \%)$ had nitrate concentrations $>45 \mathrm{mg} / \mathrm{L}$, while the mean nitrate concentration for these 357 wells was $5.76 \mathrm{mg} / \mathrm{L}$ and 113 wells (32\%) had concentrations below the detection limit ( $<0.27 \mathrm{mg} / \mathrm{L}$ or $<0.18 \mathrm{mg} / \mathrm{L})$.

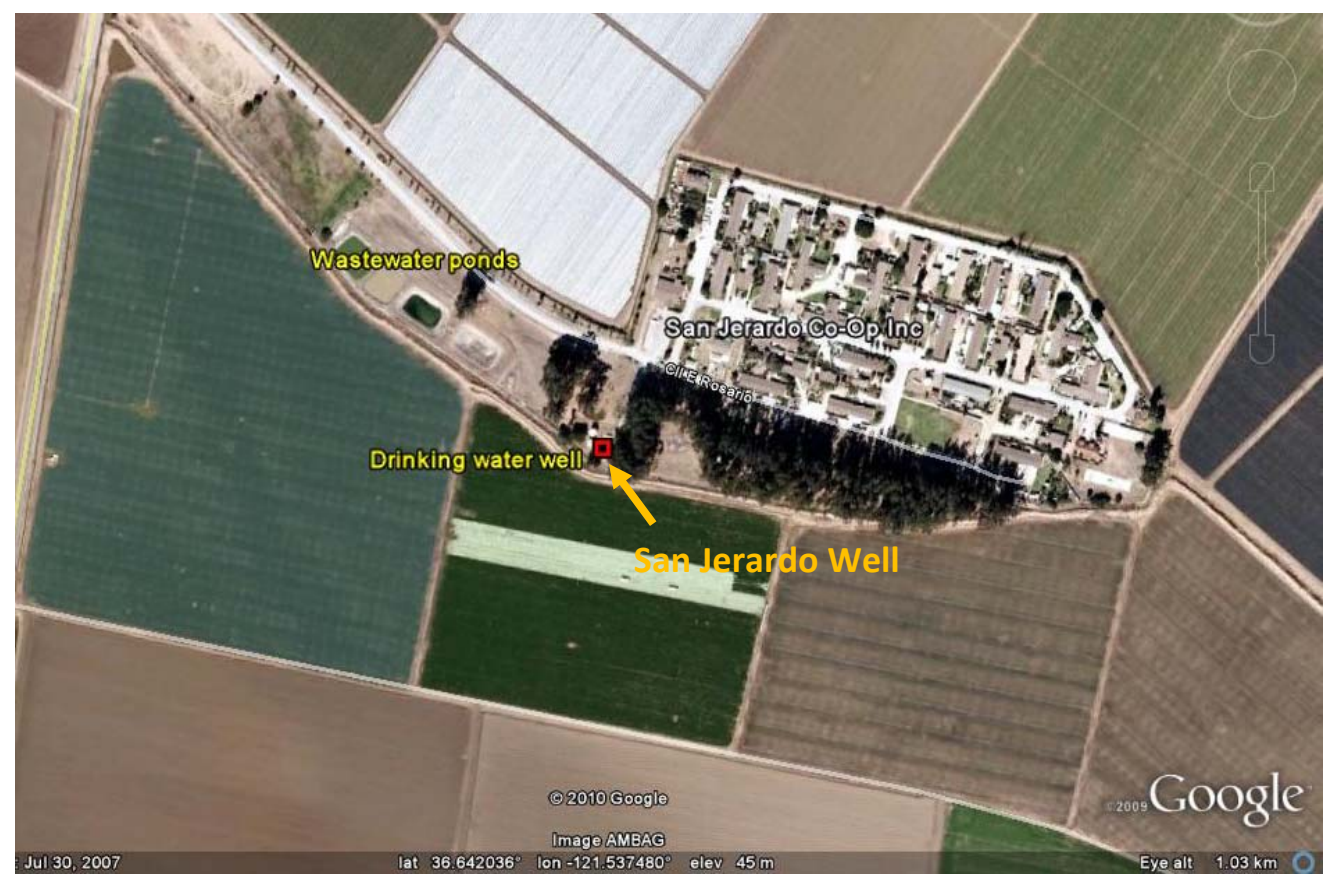

Figure 17. Google Earth image of San Jerardo Co-Op, drinking water well, surrounding agricultural fields, and nearby wastewater ponds. 


\section{Nitrate Source in Inactive San Jerardo Well}

One deep drinking water supply well, which until December, 2010 supplied water for the San Jerardo Cooperative, was examined in great detail (figure 17). A complete record of all findings and interpretation of groundwater and nitrate flow and transport in the vicinity of the well will be published in a subsequent report. Here we report the results that relate to the source of nitrate in the San Jerardo well and to the relationship between this well and other wells sampled under GAMA programs. The San Jerardo well is situated in the East Side subbasin, an area with semi-confined aquifers and locally highly elevated nitrate concentrations (MCWRA, 1997). In the survey MCWRA carried out in 1994-95, thirteen of 68 East Side wells had nitrate concentrations $>100 \mathrm{mg} / \mathrm{L}$ and $47 \%$ of wells had concentrations higher than the MCL of $45 \mathrm{mg} / \mathrm{L}$. We sampled the San Jerardo well eight times from May through December, 2010, and the nitrate concentration varied from 69 to $130 \mathrm{mg} / \mathrm{L}$ (figure 18). In basins where the water table elevation varies widely due to seasonal pumping and recharge, it is not uncommon for nitrate concentrations in production wells to vary by $50 \%$ or more over the water year (Davisson et al., 1993; Martin et al., 2004; McLay et al., 2001; Thorburn et al., 2003; Williams et al., 1998).

The San Jerardo well is surrounded by fields cultivated for strawberries, broccoli, and other row crops, where there are likely multiple applications of inorganic fertilizers each year. Triple cropping is common for row crops in the Salinas Valley; nitrapyrin and ammonium sulfate are typical fertilizers for strawberries while anhydrous synthetic $\mathrm{N}$ and $\mathrm{P}$ fertilizer is applied to broccoli typically at $200 \mathrm{lb} \mathrm{N}$ per acre. In San Jerardo well water samples from 2010, sulfate and nitrate show a similar temporal trend, with an overall decrease from May through October, while the trend for chloride is not correlated with nitrate or sulfate (figure 18), suggesting that sulfate and nitrate have the same source which is different from the chloride source. Sulfate and nitrate are both components of soil amendments and fertilizers, while chloride is not. In contrast with results from monitor wells, nitrate occurs at a much higher concentration than chloride or sulfate in the San Jerardo well. 


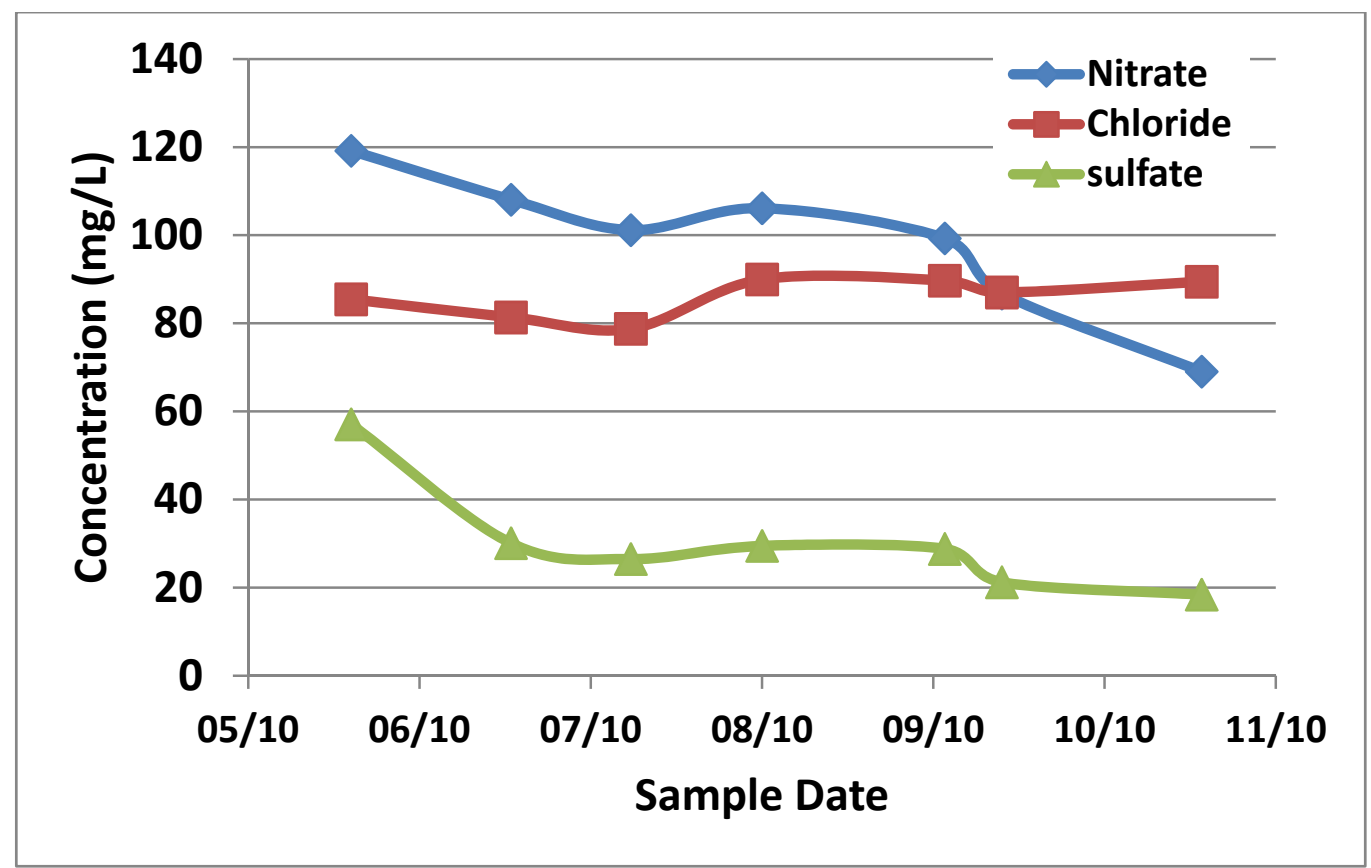

Figure 18. Major anion concentrations (not including dissolved inorganic carbon) in San Jerardo well samples from 2010.

A key resource management issue lies in assessing the effectiveness of best management practices (BMPs) on farms given that changes in surface loadings may not be seen in observation wells for decades or more. Short term (seasonal) variations are superimposed on longer term trends. A good understanding of the seasonal variation in the nitrate concentration is therefore necessary in order to assess the longer term trend in nitrate loading to aquifers. Furthermore, close examination of seasonal trends in wells offers clues to the source(s) of nitrate and to the effects of local and regional pumping. 


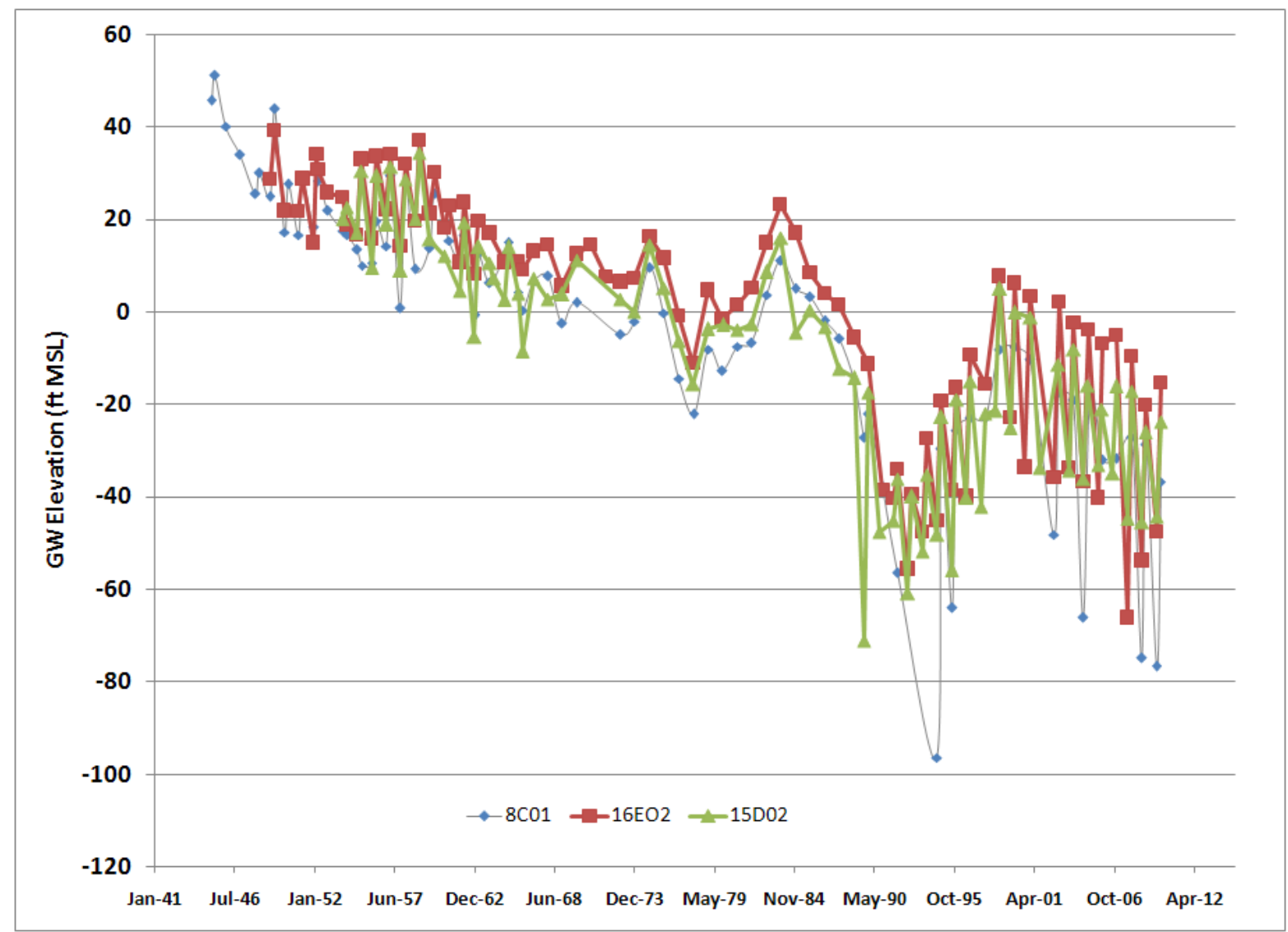

Figure 19. Historical water levels in three wells near the San Jerardo Co-op drinking water well.

Groundwater levels recorded in wells surrounding San Jerardo Cooperative show a long-term decline of nearly $100 \mathrm{ft}$. in this part of the subbasin since the 1940's (figure 19). Although water levels in the drinking water well were not available except on one occasion, an inactive well $40 \mathrm{ft}$ from the San Jerardo well was dry at $180 \mathrm{ft}$ bgs (appx. -31 ft MSL) in November and had a recorded water level of 174 $\mathrm{ft}$ bgs in December. (Although the well log for this well shows a completion depth of 260' bgs, this inactive well was filled with sediment to a depth of $180 \mathrm{ft}$ when checked in November, 2010. On the last sampling date, December 10, 2010, samples were bailed from both inactive wells. Several parameters, including those that rely on dissolved gas measurements, could therefore not be analyzed on that date.) Superimposed on the overall downward trend are fluctuations associated with the amount of precipitation (e.g., a sharp water level decline in the early 1990's corresponding with drought conditions and increased pumping), along with a large seasonal fluctuation of 30-40 ft. over the last decade. Seasonal pumping for irrigation therefore has the largest effect on water level conditions, and irrigation return flow is likely a major source of recharge in the area, along with precipitation. Small ephemeral streams that drain the nearby Gabilan range and wastewater detention ponds (visible on figure 17) are other possible minor recharge sources. Fertilizer applied to surrounding fields and seepage from the 
wastewater ponds therefore have been identified as likely sources of anthropogenic nitrate at San Jerardo (M. Keeling, personal communication).

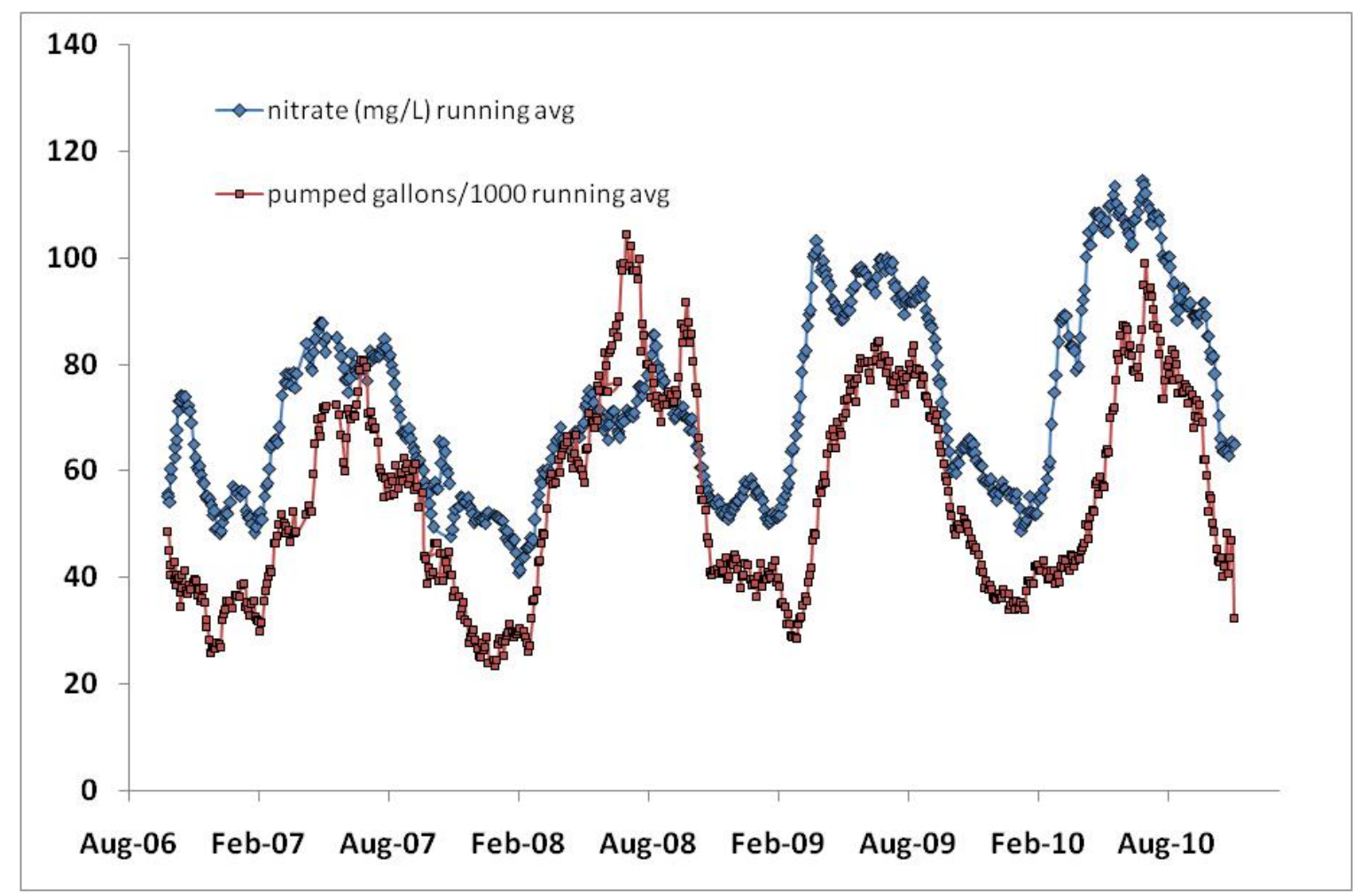

Figure 20. Three week running average of volume pumped and nitrate concentration recorded in the San Jerardo drinking water well.

The San Jerardo well has been closely monitored since it was discovered that the well produced drinking water above the MCL for nitrate. The high frequency record (samples were taken approximately every 3 days) shows that nitrate concentrations have a cyclical pattern whereby the well produces water with low nitrate concentrations during late fall and winter, undergoes a sharp rise in concentrations during early spring, with high concentrations persisting throughout the summer months (figure 20). Note that the curves in figure 20 are smoothed by plotting the 3 week running mean; raw data show large shortterm variations in concentration of up to $55 \mathrm{mg} / \mathrm{L}$ over a three day period. Nitrate concentrations are clearly correlated with the amount of water produced at the well but the amount of water produced at San Jerardo (approximately 17,000 gal/day or $19.5 \mathrm{ac}-\mathrm{ft}$ in 2007) is likely a small fraction of the groundwater produced at nearby irrigation wells. The timing of increases and decreases in production are likely similar, however, and the seasonal water level response (figure 19) is evidently a function of pumping for irrigation. 
Nitrate concentrations rise sharply in the well when the irrigation season begins and stay high (on average) throughout summer and early fall, then fall sharply back to levels closer to, but still higher than, the MCL following the typical irrigation season. Short-term variations in nitrate concentrations in the well are likely due to relatively rapid development of a cone of depression under semi-confined conditions, with shallow, nitrate-laden groundwater drawn into the well as the cone develops. However, the overall annual variation is likely related to pumping in surrounding fields and a regional drop in the water table. In that scenario, many wells draw in shallow groundwater that percolated through the vadose zone, accelerated by winter rains and by irrigation return flow.

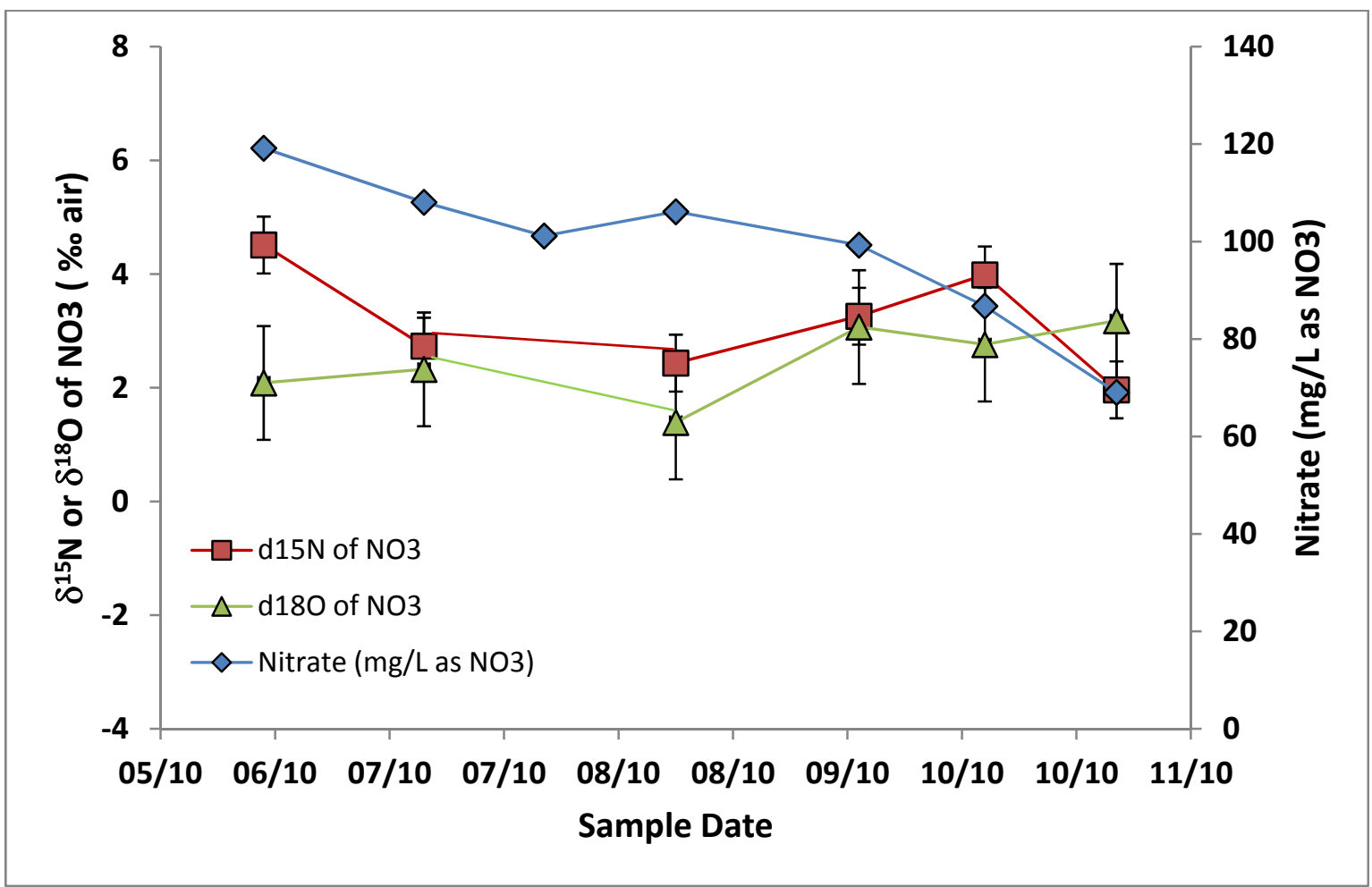

Figure 21. The temporal pattern in nitrate concentration and isotopes of nitrate in San Jerardo samples shows that the isotopic signature does not vary significantly from the range expected for inorganic $N$ fertilizer, even as the nitrate concentration decreases by $42 \%$.

The $\delta^{15} \mathrm{~N}$ values observed in samples from the San Jerardo well vary from $1.96 \%$ o to $4.51 \%$, with a mean value of $3.15 \%$. These values fall in the range expected for inorganic fertilizers, and not in the range expected for animal waste (figure 6). A similar range in $\delta^{15} \mathrm{~N}$ was observed in nitrate-contaminated groundwater near Gilroy, in the Llagas subbasin, where land use patterns are similar to the Salinas Valley and groundwater is the sole source for irrigation (Moran et al., 2005b). Nitrate in groundwater that originated as anhydrous fertilizer would retain the $\delta^{15} \mathrm{~N}$ of the source but the nitrate- $\delta^{18} \mathrm{O}$ signature acquired during nitrification of ammonia or urea may more closely reflect the oxygen isotopic signature of soil water, because biochemical exchange in the soil zone between oxygen in $\mathrm{NO}_{3}{ }^{-}$and oxygen in $\mathrm{H}_{2} \mathrm{O}$ 
can affect the nitrate- $\delta^{18} \mathrm{O}$ of the residual nitrate that is leached to groundwater (Kool et al., 2011). Observed values of nitrate- $\delta^{18} \mathrm{O}$ are $+1.4 \%$ to $+3.2 \%$, in the range observed in samples from the Arroyo Seco area, where nitrate likely has a natural source, as discussed above. It appears that nitrate- $\delta^{18} \mathrm{O}$ reflects local soil water values rather than the major source of nitrogen in groundwater at San Jerardo.

The San Jerardo well is characterized by a high dissolved oxygen concentration (Table 1a) and dissolved gas concentrations that suggest some gas loss may have taken place during sampling, but that excess nitrogen is not present (figure 5). Denitrification is not taking place in the San Jerardo area because a significant amount of dissolved oxygen is present in the groundwater. Furthermore, the isotopic signature of the nitrate, measured in seven samples from the San Jerardo well in 2010 does not vary significantly from the range of values expected for inorganic $\mathrm{N}$ fertilizer. The temporal pattern in $\delta^{15} \mathrm{~N}$ and nitrate- $\delta^{18} \mathrm{O}$ does not seem to be related to the pattern in nitrate concentrations (figure 21 ).

The San Jerardo well is screened over multiple intervals below $240 \mathrm{ft}$ bgs to a depth of approximately $390 \mathrm{ft}$, and has a low tritium concentration that hovers around the detection limit of approximately 1 $\mathrm{pCi} / \mathrm{L}$ (Table 1c). Seven out of nine of the samples have tritium concentrations just above the detection limit, within the 1 sigma error, but there is no detectable tritiogenic ${ }^{3}$ Helium in San Jerardo well water samples. Furthermore, the San Jerardo samples have radiogenic ${ }^{4} \mathrm{He}$ concentrations that point to a much older component of water produced at the well. Using an average crustal production rate of $5 \times 10^{-11} \mathrm{~cm}^{3} / \mathrm{g} \cdot \mathrm{yr}$ (Torgersen and Clarke, 1985), the observed radiogenic ${ }^{4} \mathrm{He}$ concentrations point to a component of groundwater with a subsurface residence time in the range of 1000-3700 years.

Radon activity in water produced from the San Jerardo well (average 1780; range 1630 to $2050 \mathrm{pCi} / \mathrm{L}$ ) is significantly higher than radon activities in monitor wells along the Salinas and Arroyo Seco rivers (average 310; range $<11$ to $750 \mathrm{pCi} / \mathrm{L}$ ) (figure 22). San Jerardo well water radon is negatively correlated with nitrate, being the lowest during the summer irrigation season and highest during the winter, and positively correlated with radiogenic ${ }^{4} \mathrm{He}$ (figure $22 \mathrm{~b}$ ), indicating that the high radon activities in the San Jerardo well are likely due in part to a very old water component. 

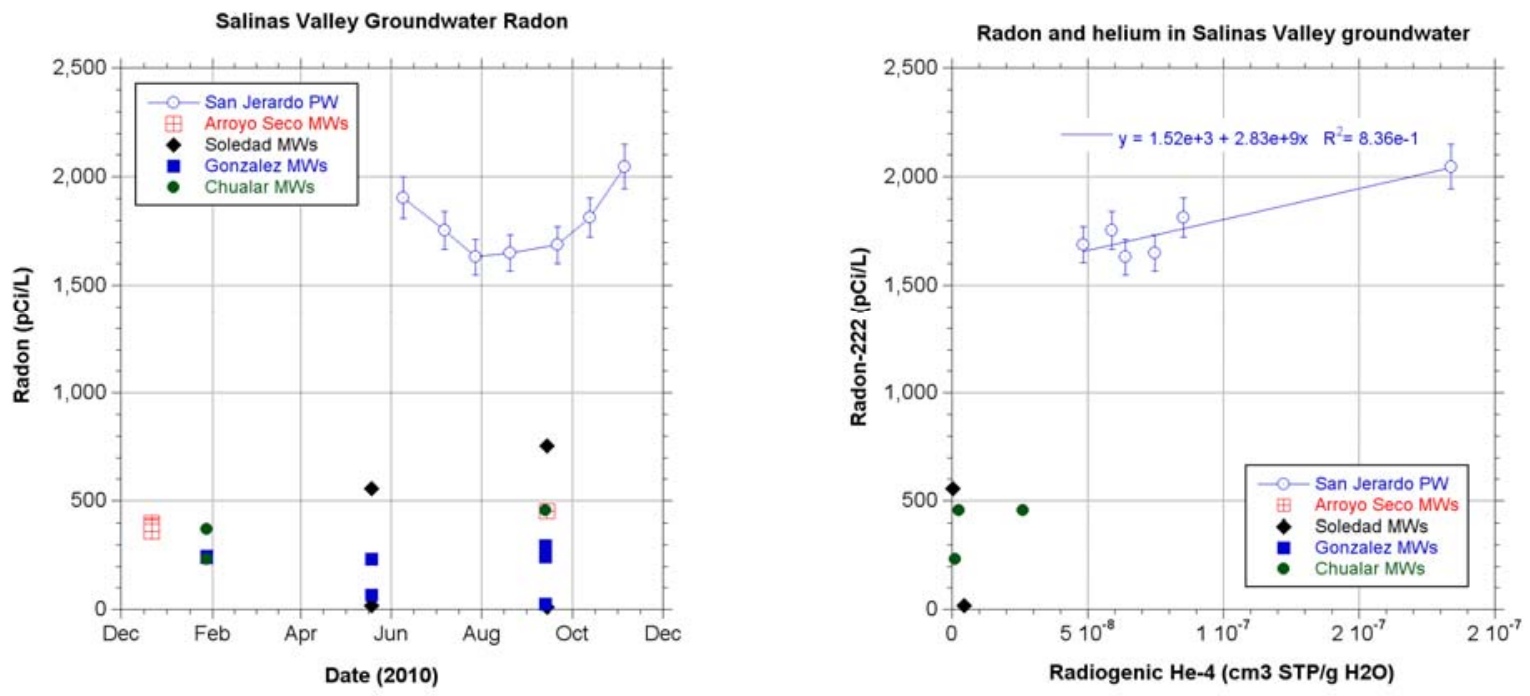

Figure 22. Radon in San Jerardo well water and in nested monitor well waters from along the Salinas and Arroyo Seco rivers. Radon was measured but not detected ( $<8$ to $20 \mathrm{pCi} / \mathrm{L}$ ) in river waters collected near the monitor well sites. Figure $23 a$ (on the left) shows time-series data; Figure $23 b$ (on the right) shows radon plotted against radiogenic ${ }^{4} \mathrm{He}$.

The combined evidence from tritium, tritiogenic ${ }^{3} \mathrm{He}$, and radiogenic ${ }^{4} \mathrm{He}$ concentrations, reveals complex recharge and flow to the capture zone of the San Jerardo well. Deeper portions of the well draw in water that recharged before agricultural activity began in the valley, while shallower intervals draw in recycled irrigation water which has a very low tritium concentration. The recycled irrigation water makes up a larger proportion of the produced water when the irrigation season begins and agricultural wells in the region draw down water levels and water that has percolated through the vadose zone migrates downward. This irrigation return water has very high nitrate concentrations, higher than those observed in the well, since water produced from the well has a component of very old, low-nitrate water. The irrigation return water may take a decade or more to reach the well capture zone, given that the vadose zone is more than 100 feet deep, but downward migration is likely enhanced by plowing, crop removal, and sprinkler irrigation in the surrounding fields. High nitrate concentrations in well water samples with very low tritium concentrations are observed in a few other wells in the Salinas Valley (figure 23), suggesting that this phenomenon is not restricted to the San Jerardo well. 
Moran et al. (2011) LLNL-TR-484186

Figure 23. Symbol (O) shows the locations of wells with very low or non-detectable tritium and moderate (> $25 \mathrm{mg} / \mathrm{L}$ ) to high ( $>100 \mathrm{mg} / \mathrm{L}$ ) nitrate concentrations.

Stable isotopes of the water molecule support the notion that irrigation return water is drawn into the well in greater proportions during late spring and early summer when the highest nitrate concentrations are recorded in the well. Figure 24 shows that the stable isotope signature of water produced from the San Jerardo well varies over the time period of sampling, with values clustered around $-7 \%$ in $\delta^{18} \mathrm{O}$ and close to the GMWL during late summer and fall, and heavier values showing an evaporative trend, as expected for irrigation return water, in spring and early summer (figure 7). 


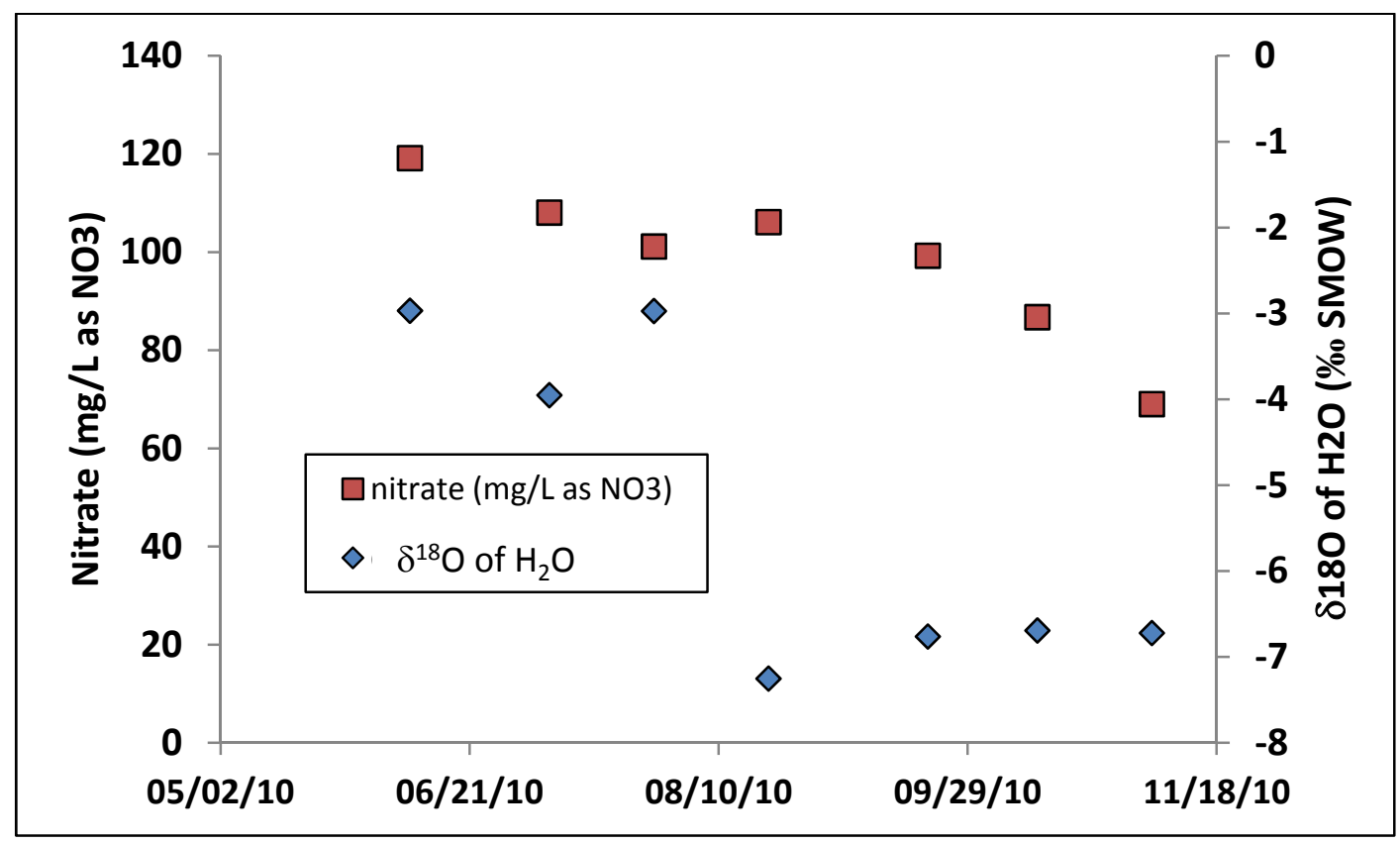

Figure 24. The temporal patterns in nitrate and $\delta^{18} \mathrm{O}$ of water in San Jerardo samples show the influence of two water sources: a high nitrate, high $\delta^{18} \mathrm{O}$ water (early samples) and a lower nitrate, low $\delta^{18} \mathrm{O}$ water source (later samples). 


\section{Summary and Conclusions}

Nitrate contamination of groundwater is severe in some portions of the Salinas Valley, where land and water use are dominated by irrigated row crop farming. In order to establish a 'background' nitrate concentrations range, wells and surface water from a relatively unimpacted portion of the basin, the Arroyo Seco Cone, were sampled for tracers of nitrate and water sources. Nitrate concentrations are low $(<4 \mathrm{mg} / \mathrm{L})$ and have not been altered by denitrification. Isotopic tracers further reveal that precipitation and some soil nitrogen are the most likely sources of nitrate in groundwater and that water moves rapidly from the stream through the upper aquifer in this important recharge area. Results from monitor wells and surface water along the main stem of the Salinas River show that denitrification affects nitrate transport at all locations examined, despite differences in the recharge rate and dominant water source. Rapid vertical transport of river water is observed near Gonzales, while slower transport of mixed river and irrigation return water is observed near Chualar, and a predominance of irrigation return water, high in nitrate, is observed near Soledad. Based on the isotopic pattern in $\mathrm{N}$ and $\mathrm{O}$ of nitrate, inorganic fertilizer is the most likely source of nitrate in Salinas River water, in the shallow groundwater near the river, and in deeper wells with high nitrate concentrations. One deep well with high nitrate, at San Jerardo, is evidently affected by the annual cycle of pumping and recharge, which brings nitrate-laden irrigation return water into the well capture zone during early spring through summer. Much of the groundwater produced from the confined and semi-confined portions of the Salinas Valley Basin is devoid of tritium, and recycling of low-tritium water applied for crop irrigation affects observed patterns in tritium, groundwater age, and nitrate.

\section{Acknowledgments:}

Personnel from the Monterey County Water Resources Agency collaborated in choosing sampling locations and provided access to monitoring wells. MCWRA supplied well construction information and historical water levels in monitor wells along the river and near San Jerardo. The San Jerardo well operators provided nitrate concentrations and pumping data for 2006-2010. The Central Coast Regional Water Quality Control Board provided information on sources of existing data and documents. 


\section{References:}

Bernhardt, E. S., Hall, R. O., and Likens, G. E., 2002. Whole-system estimates of nitrification and nitrate uptake in streams of the Hubbard Brook Experimental Forest. Ecosystems 5, 419-430.

Bohlke, J. K., 2002. Groundwater recharge and agricultural contamination. Hydrogeol. J. 10, 153-179.

Bohlke, J. K. and Denver, J. M., 1995. Combined use of groundwater dating, chemical, and isotopic analyses to resolve the history and fate of nitrate contamination in two agricultural watersheds, Atlantic Coastal Plain, Maryland. Water Resources Research 31, 2319-2339.

Butturini, A. and Sabater, F., 1999. Importance of transient storage zones for ammonium and phosphate retention in a sandy-bottom Mediterranean stream. Freshwater Biology 41, 593-603.

California DWR, 2003. California's Groundwater: Bulletin 118 (Update 2003). California Department of Water Resources, 246, http://www.water.ca.gov/groundwater/\# http://www.water.ca.gov/groundwater/bulletin118/update2003.cfm.

Coplen, T. B. and Kendall, C., 2000. Stable Hydrogen and Oxygen Isotope Ratios for Selected Sites of the U.S. Geological Survey's NASQAN and Benchmark Surface-water Networks. USGS Open-File Report 00-160, 424, http://pubs.water.usgs.gov/ofr-00-160.

Davisson, M. L., Criss, R. E., and Campbell, K. R., 1993. Preliminary report on the stable isotope imaging and characterization of surface and ground water resources in the southern Sacramento Valley. Lawrence Livermore National Laboratory

Domagalski, J. L., Phillips, S. P., Bayless, E. R., Zamora, C., Kendall, C., Wildman, R. A., and Hering, J. G., 2008. Influences of the unsaturated, saturated, and riparian zones on the transport of nitrate near the Merced River, California, USA. Hydrogeol. J. 16, 675-690.

Fogg, G. E., LaBolle, E. M., and Weissmann, G. S., 1999. Groundwater vulnerability assessment: Hydrologic perspective and example from Salinas Valley, California, Assessment of Non-Point Source Pollution in the Vadose Zone (Geophysical Monograph 108). American Geophysical Union.

Fogg, G. E., Rolston, D. E., LaBolle, E. M., Burow, K. R., Maserjian, L. A., Decker, D., and Carle, S. F., 1995. Matrix diffusion and contaminant transport in granular geologic materials, with case study of nitrate contamination in Salinas Valley, California. Monterey County Water Resources Agency and U.S. Geologic Survey (Water Resources Research Award No. 14-08-0001-G1909), 71

Grimaldi, C. and Chaplot, V., 2000. Nitrate depletion during within-stream transport: Effects of exchange processes between streamwater, the hyporheic and riparian zones. Water Air and Soil Pollution 124, 95-112.

Heaton, T. H. E., 1987. N-15/N-14 Ratios of Nitrate and Ammonium in Rain at Pretoria, South-Africa. Atmos. Environ. 21, 843-852.

Kendall, C., 1998. Tracing nitrogen sources and cycling in catchments. In: Kendall, C. and McDonnell, J. J. Eds.), Isotope Tracers in Catchment Hydrology. Elsevier, New York.

Kennedy Jenks, L., 2004. Hydrostratigraphic Analysis of the Northern Salinas Valley, Final Report: . Monterey County Water Resources Agency, 112, http://www.mcwra.co.monterey.ca.us/Agency data/Hydrogeologic\%20Reports/HS Analysis N SV/HS Analysis NSV.htm.

Kool, D.M., Wrage, N., Oenema, O., Van Kessel, C., Van Groenigen, J.W., 2011. Oxygen exchange with water alters the oxygen isotopic singature of nitrate in soil ecosystems. Soil Biol. and Biochem. 43, 1180-1185.

Kulongoski, J. T. and Belitz, K., 2011. Status and Understanding of Groundwater Quality in the Monterey Bay and Salinas Valley Groundwater Basins, 2005: California GAMA Priority Basin Project. U.S. 
Geological Survey Scientific Investigations Report (in press), 77, http://www.swrcb.ca.gov/water issues/programs/gama/report depot.shtml http://www.waterboards.ca.gov/gama/docs/nsfb dsr final.pdf.

Kulongoski, J. T., Belitz, K., and Dawson, B. J., 2007. Ground-Water Quality Data in the Monterey Bay and Salinas Valley Basins, California, 2005-Results from the California GAMA Program. U.S. Geological Survey Data Series Report 167, 84, http://www.swrcb.ca.gov/water issues/programs/gama/report depot.shtml http://www.waterboards.ca.gov/gama/docs/nsfb dsr final.pdf.

Martin, C., Aquilina, L., Gascuel-Odoux, C., Molenat, J., Faucheux, M., and Ruiz, L., 2004. Seasonal and interannual variations of nitrate and chloride in stream waters related to spatial and temporal patterns of groundwater concentrations in agricultural catchments. Hydrol. Process. 18, 12371254.

McLay, C. D. A., Dragten, R., Sparling, G., and Selvarajah, N., 2001. Predicting groundwater nitrate concentrations in a region of mixed agricultural land use: a comparison of three approaches. Environmental Pollution 115, 191-204.

MCWRA, 1997. Water Resources Data Report (Water Year 1994-1995). Monterey County Water Resources Agency: Water Resources Management Division, 143, http://www.mcwra.co.monterey.ca.us/Agency data/Hydrogeologic\%20Reports/WaterResource sDataReport/WaterResourcesDataReport.htm.

Moran, J. E., Hudson, G. B., Eaton, G. F., and Leif, R., 2002. A contamination vulnerability assessment for the Livermore-Amador and Niles Cone groundwater basins: Report to the California State Water Resources Control Board. Lawrence Livermore National Laboratory, UCRL-AR-148831, 25

Moran, J. E., Hudson, G. B., Eaton, G. F., and Leif, R., 2004a. A contamination vulnerability assessment for the Sacramento area groundwater basin. Lawrence Livermore National Laboratory, UCRL-TR203258, 46, http://www.waterboards.ca.gov/water issues/programs/gama/gamadocs.shtml.

Moran, J. E., Hudson, G. B., Eaton, G. F., and Leif, R., 2004b. A contamination vulnerability assessment for the Santa Clara and San Mateo County Groundwater Basins. Lawrence Livermore National Laboratory, UCRL-TR-201929, 46, http://www.waterboards.ca.gov/water issues/programs/gama/gamadocs.shtml.

Moran, J. E., Hudson, G. B., Eaton, G. F., and Leif, R., 2005a. California GAMA Program: Groundwater Ambient Monitoring and Assessment Results for the Sacramento Valley and Volcanic Provinces of Northern California. Lawrence Livermore National Laboratory, UCRL-TR-209191, 73, http://www-r.llnl.gov/tid/lof/documents/pdf/315637.pdf.

Moran, J. E., McNab, W. W., Esser, B. E., and Hudson, G. B., 2005b. California GAMA program: Sources and transport of nitrate in shallow groundwater in the Llagas Basin of Santa Clara County, California. Lawrence Livermore National Laboratory, UCRL-TR-213705, 37

Neal, C. and Jarvie, H. P., 2005. Agriculture, community, river eutrophication and the water framework directive. Hydrol. Process. 19, 1895-1901.

Nolan, B. T., 2001. Relating nitrogen sources and aquifer susceptibility to nitrate in shallow ground waters of the United States. Ground Water 39, 290-299.

Puckett, L. J. and Cowdery, T. K., 2002. Transport and fate of nitrate in a glacial outwash aquifer in relation to ground water age, land use practices, and redox processes. Journal of Environmental Quality 31, 782-796. 
Puckett, L. J., Zamora, C., Essaid, H., Wilson, J. T., Johnson, H. M., Brayton, M. J., and Vogel, J. R., 2008. Transport and Fate of Nitrate at the Ground-Water/Surface-Water Interface. J Environ Qual 37, 1034-1050.

Ruehl, C. R., Fisher, A. T., Los Huertos, M., Wankel, S. D., Wheat, C. G., Kendall, C., Hatch, C. E., and Shennan, C., 2007. Nitrate dynamics within the Pajaro River, a nutrient-rich, losing stream. J. N. Am. Benthol. Soc. 26, 191-206.

Thorburn, P. J., Biggs, J. S., Weier, K. L., and Keating, B. A., 2003. Nitrate in groundwaters of intensive agricultural areas in coastal Northeastern Australia. Agriculture Ecosystems \& Environment 94, 49-58.

Torgersen, T. and Clarke, W. B., 1985. Helium accumulation in groundwater, I: An evaluation of sources and the continental flux of crustal $4 \mathrm{He}$ in the Great Artesian Basin, Australia. Geochimica et Cosmochimica Acta 49, 1211-1218.

Vengosh, A., Gill, J., Davisson, M. L., and Hudson, G. B., 2002. A multi-isotope (B, Sr, O, H, and C) and age dating (H-3-He-3 and C-14) study of groundwater from Salinas Valley, California: Hydrochemistry, dynamics, and contamination processes. Water Resources Research 38, 1008.

Williams, A. E., Johnson, J. A., Lund, L. J., and Kabala, Z. J., 1998. Spatial and temporal variations in nitrate contamination of a rural aquifer, California. Journal of Environmental Quality 27, 11471157.

Xue, D., Botte, J., De Baets, B., Accoe, F., Nestler, A., Taylor, P., Van Cleemput, O., Berglund, M., and Boeckx, P., 2009. Present limitations and future prospects of stable isotope methods for nitrate source identification in surface- and groundwater. Water Research 43, 1159-1170. 
Table 1a. Sample characteristics and results for field parameters

\begin{tabular}{|c|c|c|c|c|c|c|c|c|c|c|c|c|}
\hline $\begin{array}{ll}\text { LLNL ID } \\
\end{array}$ & Area & Location ID & Sample Date & Latitude & Longitude & $\begin{array}{l}\text { Perforations } \\
\text { (ft bgs) }\end{array}$ & $\begin{array}{c}\text { Completion } \\
\text { Depth } \\
\text { (ft bgs) }\end{array}$ & $\begin{array}{l}\text { Field Temp } \\
\left({ }^{\circ} \mathrm{C}\right)\end{array}$ & $\begin{array}{l}\text { Field Conductivity } \\
(\mu \mathrm{s} / \mathrm{cm})\end{array}$ & $\begin{array}{l}\text { Field } \\
\mathrm{pH}\end{array}$ & $\begin{array}{l}\text { Field DO } \\
(\mathrm{mg} / \mathrm{L})\end{array}$ & $\begin{array}{c}\text { Field ORP } \\
(\mathrm{mV})\end{array}$ \\
\hline \multicolumn{13}{|c|}{ Monitor Wells } \\
\hline 107809 & Arroyo Seco & 18S/6E-26L01 & $12 / 22 / 2009$ & 36.33635 & 121.28870 & $55-75$ & 80 & 14.7 & 259 & 6.8 & 4.2 & 100 \\
\hline 107811 & Arroyo Seco & 18S/6E-26K01 & $12 / 22 / 2009$ & 36.33653 & 121.28658 & $70-80$ & 80 & 13.9 & 298 & 7.1 & 3.7 & 82 \\
\hline 107812 & Arroyo Seco & 18S/6E-26K03 & $12 / 22 / 2009$ & 36.33658 & 121.28727 & $50-70$ & 75 & 15.8 & 269 & 7.1 & 3.6 & 78 \\
\hline 107813 & Arroyo Seco & 18S/6E-26K02 & $12 / 22 / 2009$ & 36.33650 & 121.28724 & $140-160$ & 160 & 14.0 & 230 & 7.0 & 3.9 & 75 \\
\hline 107901 & Chualar & $16 \mathrm{~S} / 04 \mathrm{E}-08 \mathrm{H} 03$ deep & $01 / 28 / 2010$ & 36.55533 & 121.54736 & $240-290$ & 295 & 17.0 & 678 & 7.2 & 0.4 & 80 \\
\hline 107902 & Chualar & 16S/04E-08H04 shallow & $01 / 28 / 2010$ & 36.55533 & 121.54736 & $85-135$ & 140 & 16.9 & 561 & 7.3 & 2.9 & 63 \\
\hline 107904 & Gonzales & 17S/05E 06 C02 A shallow & $01 / 28 / 2010$ & 36.48824 & 121.46806 & $60-110$ & 115 & 18.2 & 458 & 7.7 & 5.2 & -60 \\
\hline 107905 & Gonzales & 175/05E 06 C01 B deep & $01 / 28 / 2010$ & 36.48824 & 121.46806 & $250-290$ & 300 & 18.2 & 545 & 7.6 & 5.4 & -20 \\
\hline 108009 & Gonzales & 17S/05E-31P01 deep & $05 / 19 / 2010$ & 36.48823 & 121.46851 & $255-295$ & 300 & 17.6 & 323 & 8.1 & & 32 \\
\hline 108010 & Gonzales & 17S/05E-31P02 shallow & $05 / 19 / 2010$ & 36.48823 & 121.46851 & $60-110$ & 115 & 17.4 & 401 & 7.2 & & -78 \\
\hline 108011 & Soledad & 17S/05E-33R01 deep & 05/19/2010 & 36.40458 & 121.31610 & $200-250$ & 260 & 17.2 & 1850 & 7.2 & & 35 \\
\hline 108012 & Soledad & 175/05E-33R02 shallow & 05/19/2010 & 36.40458 & 121.31610 & $50-115$ & 120 & 17.4 & 1690 & 7.1 & & 5 \\
\hline 108409 & Chualar & $16 \mathrm{~S} / 04 \mathrm{E}-08 \mathrm{H} 03$ deep & 09/13/2010 & 36.55533 & 121.54736 & $240-290$ & 295 & 17.2 & 545 & 6.9 & 0.2 & -17 \\
\hline 108410 & Chualar & 16S/04E-08H04 shallow & $09 / 13 / 2010$ & 36.55533 & 121.54736 & $85-135$ & 140 & 16.8 & 661 & 7.0 & 1.1 & -17 \\
\hline 108412 & Gonzales & 17S/05E 06 C02 A shallow & $09 / 13 / 2010$ & 36.48824 & 121.46806 & $60-110$ & 115 & 18.5 & 509 & 7.3 & 0.2 & -101 \\
\hline 108413 & Gonzales & 17S/05E 06 C01 B deep & $09 / 13 / 2010$ & 36.48824 & 121.46806 & $250-290$ & 300 & 18.0 & 478 & 7.2 & 0.2 & -29 \\
\hline 108415 & Gonzales & 17S/05E-31P02 shallow & $09 / 13 / 2010$ & 36.48823 & 121.46851 & $60-110$ & 115 & 17.6 & 635 & 7.2 & 0.8 & -90 \\
\hline 108416 & Gonzales & 17S/05E-31P01 deep & $09 / 13 / 2010$ & 36.48823 & 121.46851 & $255-295$ & 300 & 17.9 & 510 & 7.6 & 1.8 & -37 \\
\hline 108417 & Arroyo Seco & 18S/06E-35F02 shallow & $09 / 14 / 2010$ & 36.32374 & 121.29123 & & & 15.5 & 345 & 7.1 & 7.6 & -4 \\
\hline 108419 & Soledad & 175/05E-33R02 shallow & $09 / 14 / 2010$ & 36.40458 & 121.31610 & $50-115$ & 120 & 17.3 & 2273 & 6.9 & 1.3 & -17 \\
\hline 108420 & Soledad & 17S/05E-33R01 deep & 09/14/2010 & 36.40458 & 121.31610 & $200-250$ & 260 & 17.8 & 2459 & 7.0 & 3.3 & -11 \\
\hline \multicolumn{13}{|c|}{ Surface Water } \\
\hline 107810 & Arroyo Seco & Arroyo Seco@MWs & $12 / 22 / 2009$ & 36.33633 & 121.28836 & & & 9.4 & 238 & 7.4 & 5.2 & 80 \\
\hline 107903 & Chualar & Salinas R @ Chualar Bridge & $01 / 28 / 2010$ & 36.55603 & 121.54880 & & & 11.0 & 325 & 7.9 & 10.8 & 61 \\
\hline 107907 & Gonzales & Salinas R @ Gonzales Bridge & $01 / 28 / 2010$ & 36.48811 & 121.46866 & & & 11.4 & 344 & 8.0 & 10.8 & 2 \\
\hline 108008 & Gonzales & Salinas R @ Gonzales Bridge & 05/19/2010 & 36.48811 & 121.46866 & & & 15.6 & 547 & 7.8 & & -27 \\
\hline 108013 & Arroyo Seco & Arroyo Seco @ Arroyo Seco Rd Bridge & $05 / 19 / 2010$ & 36.39939 & 121.32479 & & & 22.0 & 242 & 8.2 & & -7 \\
\hline 108363 & Chualar & Salinas R@ Chualar Bridge & 08/20/2010 & 36.55603 & 121.54880 & & & 19.6 & 324 & 7.6 & & -25 \\
\hline 108364 & Gonzales & Salinas R @ Gonzales Bridge & $08 / 20 / 2010$ & 36.48811 & 121.46866 & & & 22.9 & 342 & 8.1 & & -34 \\
\hline 108411 & Chualar & Salinas R @ Chualar Bridge & $09 / 13 / 2010$ & 36.55603 & 121.54880 & & & 17.3 & 383 & 7.7 & 10.4 & 5 \\
\hline 108414 & Gonzales & Salinas R @ Gonzales Bridge & $09 / 13 / 2010$ & 36.48811 & 121.46866 & & & & & & & \\
\hline 108418 & Arroyo Seco & Arroyo Seco@ Thorne Rd Bridge & $09 / 14 / 2010$ & 36.32236 & -121.29228 & & & & & & & \\
\hline 108546 & Chualar & Salinas R@ Chualar Bridge & $11 / 05 / 2010$ & 36.55603 & 121.54880 & & & 15.2 & 632 & 8.2 & 11.4 & 6 \\
\hline \multicolumn{13}{|c|}{ San Jerardo } \\
\hline 108014 & San Jerardo Co-op & San Jerardo deep PW & 06/09/2010 & 36.64118 & 121.53574 & $240-390$ (3 sections) & 440 & 19.5 & 313 & 6.1 & 7.9 & 105 \\
\hline 108191 & San Jerardo Co-op & San Jerardo deep PW & 07/07/2010 & 36.64118 & 121.53574 & 240-390 (3 sections) & 440 & 19.3 & 682 & 6.3 & NM & 158 \\
\hline 108197 & San Jerardo Co-op & San Jerardo deep PW & 07/28/2010 & 36.64118 & 121.53574 & 240-390 (3 sections) & 440 & 19.1 & 583 & 6.3 & NM & 36 \\
\hline 108362 & San Jerardo Co-op & San Jerardo deep PW & 08/20/2010 & 36.64118 & 121.53574 & 240-390 (3 sections) & 440 & 19.3 & 585 & 6.5 & NM & 40 \\
\hline 108365 & San Jerardo Co-op & San Jerardo deep PW & $09 / 21 / 2010$ & 36.64118 & 121.53574 & $240-390$ (3 sections) & 440 & 19.3 & 807 & 6.6 & 9.6 & 28 \\
\hline 108366 & San Jerardo Co-op & San Jerardo deep PW & $10 / 13 / 2010$ & 36.64118 & 121.53574 & $240-390$ (3 sections) & 440 & 19.5 & 814 & 6.3 & 9.0 & 47 \\
\hline 108531 & San Jerardo Co-op & San Jerardo deep PW & $11 / 05 / 2010$ & 36.64118 & 121.53574 & 240-390 (3 sections) & 440 & 19.8 & 810 & 6.4 & 8.5 & 40 \\
\hline 108595 & San Jerardo Co-op & San Jerardo shallow PW & $12 / 10 / 2010$ & & & $70-252$ (7 sections) & 260 & & & & & \\
\hline 108596 & San Jerardo Co-op & San Jerardo deep PW & $12 / 10 / 2010$ & 36.64118 & 121.53574 & $240-390$ (3 sections) & 440 & & & & & \\
\hline
\end{tabular}


Table 1b. Results for nitrate and nitrate-related parameters.

\begin{tabular}{|c|c|c|c|c|c|c|c|c|c|c|c|c|c|c|c|c|c|c|c|c|c|}
\hline ULNL ID & Area & Location ID & Sample Date & $\begin{array}{c}\begin{array}{c}\text { Fluoride } \\
(\mathrm{m} / \mathrm{L})\end{array} \\
\end{array}$ & $\begin{array}{r}\text { Chloride } \\
(\mathrm{mg} / \mathrm{L})\end{array}$ & $\begin{array}{r}\text { Nitrite as } \\
\text { NO2 } \\
(\mathrm{mg} / \mathrm{L})\end{array}$ & $\begin{array}{r}\text { Bromide } \\
(\mathrm{mg} / \mathrm{L})\end{array}$ & $\begin{array}{r}\text { Nitrate as } \\
\text { No3 } \\
(\mathrm{mg} / \mathrm{L})\end{array}$ & $\begin{array}{r}\mathrm{NO} / \mathrm{Cl} \\
\text { molar ratio }\end{array}$ & $\begin{array}{l}\text { Sulfate } \\
(\mathrm{mg} / \mathrm{L})\end{array}$ & $\begin{array}{l}\text { Phosphate } \\
\text { (mg/L) } \% \text { a }\end{array}$ & $\begin{array}{r}\mathrm{CH} 4 \\
\text { at } 1 \mathrm{~atm})\end{array}$ & $\begin{array}{r}\mathrm{CO2} \\
\text { (\% at 1 } \\
\text { atm) }\end{array}$ & $\begin{array}{r}\mathrm{N} 2 \\
\text { (cm3 stP/g } \\
\text { H2O) }\end{array}$ & $\begin{array}{r}02 \\
\text { (cm3 STP/g } \\
\text { H2O) }\end{array}$ & $\begin{array}{r}\text { Ar } \\
\text { (cm3 STP/g } \\
\text { H2O) }\end{array}$ & $\begin{array}{c}\text { Excess N2 } \\
\text { as No3 } \\
(\mathrm{mg} / \mathrm{L})\end{array}$ & $\begin{array}{c}15 \mathrm{~N} \text { of NO3 } \\
\text { (\%o air) }\end{array}$ & $\begin{array}{r}180 \text { of } \\
\quad \% \text { a ar }\end{array}$ & $\begin{array}{l}\text { ff NO3 } \\
\text { air) }\end{array}$ & $\begin{array}{c}\text { Fraction } \\
\text { denitrified }\end{array}$ \\
\hline \multicolumn{22}{|l|}{ Monitor Wells } \\
\hline 107809 & Arroyo Seco & 18S/6E-26L01 & 12/22/2009 & $<0.07$ & 5.6 & & $<0.12$ & 2.0 & 0.204 & 48 & $<0.23$ & 0.00031 & 0.00073 & 0.01694 & 0.00812 & 0.00042 & $<7$ & $0.76 \pm 0.5$ & $0.76 \pm$ & 1.0 & \\
\hline 107811 & Arroyo Seco & 18S/6E-26K01 & 12/22/2009 & $<0.07$ & 4.8 & & $<0.12$ & 1.1 & 0.135 & 41 & $<0.23$ & 0.00027 & 0.00108 & 0.01820 & 0.00900 & 0.00045 & $<7$ & $-0.27 \pm 0.5$ & $1.03 \pm$ & 1.0 & \\
\hline 107812 & Arroyo Seco & 18S/6E-26K03 & $12 / 22 / 2009$ & $<0.07$ & 6.4 & & $<0.12$ & 3.3 & 0.295 & 54 & $<0.23$ & 0.00024 & 0.00101 & 0.01752 & 0.00852 & 0.00043 & $<7$ & $0.28 \pm 0.5$ & $2.59 \pm$ & 1.0 & \\
\hline 107813 & Arroyo Seco & 18S/6E-26K02 & $12 / 22 / 2009$ & $<0.07$ & 6.0 & & $<0.12$ & 0.9 & 0.080 & 53 & & 0.00030 & 0.00078 & 0.02200 & 0.00895 & 0.00048 & $<7$ & $-0.71 \pm 0.5$ & $-1.83 \pm$ & 1.0 & \\
\hline 107901 & Chualar & 16S/04E-08H03 deep & 01/28/2010 & $<0.07$ & 29.2 & & $<0.12$ & 4.0 & 0.078 & 127 & $<0.23$ & 0.00041 & 0.00344 & 0.02014 & 0.00240 & 0.00042 & 18.0 & $11.72 \pm 0.5$ & 15.96 & 1.0 & $82 \%$ \\
\hline 107902 & Chualar & 165/04E-08H04 shallow & 01/28/2010 & 0.30 & 22.3 & & $<0.12$ & 1.5 & 0.039 & 95 & $<0.23$ & 0.00053 & 0.00274 & 0.01976 & 0.00195 & 0.00043 & 14.7 & & & & $91 \%$ \\
\hline $\begin{array}{l}107904 \\
107095\end{array}$ & Gonzales & 175/05E 06 C02 A shallow & $01 / 28 / 2010$ & $<0.07$ & 13.7 & & $<0.12$ & 0.7 & 0.028 & 71 & $<0.23$ & 0.00040 & 0.00160 & 0.01652 & 0.00232 & 0.00037 & $<7$ & & & & \\
\hline $\begin{array}{l}107905 \\
108009\end{array}$ & $\begin{array}{l}\text { Gonzales } \\
\text { Gonzales }\end{array}$ & $\begin{array}{l}\text { 17S/05E } 06 \text { C01 B deep } \\
175 \text { S05E-31P01 deep }\end{array}$ & 01/28/2010 & $<0.07$ & $\begin{array}{r}26.5 \\
17.5\end{array}$ & & $<0.12$ & 4.2 & 0.091 & 107 & $<0.23$ & 0.00040 & 0.00220 & 0.01679 & 0.00234 & 0.00039 & $<7$ & $14.84 \pm 0.5$ & $18.76 \pm$ & 1.0 & \\
\hline $\begin{array}{l}108009 \\
108010\end{array}$ & $\begin{array}{l}\text { Gonzales } \\
\text { Gonzales }\end{array}$ & $\begin{array}{l}\text { 1155/05E-31901 deep } \\
\text { 17S/05E-31P02 shallow }\end{array}$ & $\begin{array}{l}\text { 00/19/2010 } \\
05 / 19 / 2010\end{array}$ & $\begin{array}{l}0.04 \\
0.21\end{array}$ & $\begin{array}{l}17.5 \\
17.8\end{array}$ & & $\begin{array}{l}<0.12 \\
<0.12\end{array}$ & $\begin{array}{r}50.6 \\
<0.1\end{array}$ & 0.182 & $\begin{array}{l}90 \\
92\end{array}$ & & $\begin{array}{l}0.00022 \\
0.00025\end{array}$ & $\begin{array}{l}0.00038 \\
0.00181\end{array}$ & $\begin{array}{l}0.01514 \\
0.01997\end{array}$ & $\begin{array}{l}0.00033 \\
0.00263\end{array}$ & $\begin{array}{l}0.00036 \\
0.00043\end{array}$ & $\begin{array}{l}<7 \\
<7\end{array}$ & $11.69 \pm 0.5$ & $12.43 \pm$ & 1.0 & \\
\hline 108011 & Soledad & 17S/05E-33R01 deep & $05 / 19 / 2010$ & $<0.07$ & 182.0 & & $<0.12$ & 186.4 & 0.585 & 704 & & 0.00036 & 0.00566 & 0.02038 & 0.00408 & 0.00042 & 14.3 & $5.16 \pm 0.5$ & $5.37 \pm$ & 1.0 & $7 \%$ \\
\hline 108012 & Soledad & 175/05E-33R02 shallow & 05/19/2010 & $<0.07$ & 124.1 & & $<0.12$ & 229.6 & 1.057 & 632 & & 0.00037 & 0.00618 & 0.02322 & 0.00279 & 0.00042 & 32.4 & $8.04 \pm 0.5$ & $2.09 \pm$ & 1.0 & $12 \%$ \\
\hline 108409 & Chualar & 165/04E--08H03 deep & 09/13/2010 & $<0.2$ & 25.1 & $<1$ & $<0.8$ & 0.2 & 0.005 & 100 & & 0.00068 & 0.00016 & 0.01708 & 0.00499 & 0.00039 & $<7$ & $10.44 \pm 0.5$ & $11.77 \pm$ & 1.0 & \\
\hline 108410 & Chualar & 16S/04E-08H04 shallow & 09/13/2010 & $<0.2$ & 35.1 & $<1$ & $<0.8$ & 5.4 & 0.088 & 121 & & 0.00064 & 0.00015 & 0.01857 & 0.00408 & 0.00039 & 8.9 & $8.30 \pm 0.5$ & $9.14 \pm$ & 1.0 & $62 \%$ \\
\hline 108412 & Gonzales & 175/05E 06 C02 A shallow & 09/13/2010 & $<0.2$ & 22.9 & $<1$ & $<0.8$ & $<0.1$ & & 73 & & 0.00069 & 0.00015 & 0.01900 & 0.00380 & 0.00042 & $<7$ & & & & \\
\hline 108413 & Gonzales & 175/05E 06 C01 B deep & 09/13/2010 & $<0.2$ & 23.5 & $<1$ & $<0.8$ & 1.3 & 0.032 & 89 & & 0.00066 & 0.00012 & 0.01560 & 0.00323 & 0.00037 & $<7$ & $17.10 \pm 0.5$ & $18.27 \pm$ & 1.0 & \\
\hline 108415 & Gonzales & 175/05E-31P02 shallow & 09/13/2010 & $<0.2$ & 18.9 & $<1$ & $<0.8$ & 0.3 & 0.008 & 86 & & 0.00072 & 0.00008 & 0.01897 & 0.00383 & 0.00042 & $<7$ & & & & \\
\hline 108416 & Gonzales & 17S/05E-31P01 deep & 09/13/2010 & $<0.2$ & 20.0 & $<1$ & $<0.8$ & 0.7 & 0.020 & 88 & & 0.00060 & 0.00007 & 0.01469 & 0.00387 & 0.00036 & $<7$ & & & & \\
\hline 108417 & Arroyo Seco & 18S/06E-35F02 shallow & 09/14/2010 & $<0.2$ & 6.3 & $<1$ & $<0.8$ & 0.5 & 0.048 & 48 & & 0.00070 & 0.00010 & 0.01729 & 0.00617 & 0.00038 & $<7$ & & & & \\
\hline 108419 & Soledad & 17S/05E-33R02 shallow & $09 / 14 / 2010$ & $<0.2$ & 120.5 & $<1$ & $<0.8$ & 204.2 & 0.968 & 527 & & 0.00070 & 0.00006 & 0.01853 & 0.00306 & 0.00037 & 16.4 & $8.23 \pm 0.5$ & & & $7 \%$ \\
\hline 108420 & Soledad & 17S/05E-33R01 deep & 09/14/2010 & $<0.2$ & 180.0 & $<1$ & $<0.8$ & 174.7 & 0.554 & 642 & & 0.00063 & 0.00006 & 0.01678 & 0.00439 & 0.00039 & $<7$ & $8.20 \pm 0.5$ & & & \\
\hline \multicolumn{22}{|l|}{ Surface Water } \\
\hline 107810 & Arroyo Seco & $\begin{array}{l}\text { Arroyo Seco @ MWs } \\
\text { Salinas B @ Chyalar Bridge }\end{array}$ & $12 / 22 / 2009$ & $<0.07$ & 5.6 & & $<0.12$ & 0.3 & 0.035 & 48 & $<0.23$ & 0.00022 & 0.00018 & 0.01630 & 0.00884 & 0.00042 & & & & & \\
\hline 107903 & Chualar & & $01 / 28 / 2010$ & $<0.07$ & 22.8 & & $<0.12$ & 3.2 & 0.080 & 71 & $<0.23$ & 0.00046 & 0.00062 & 0.01598 & 0.00747 & 0.00041 & & $7.78 \pm 0.5$ & $5.25 \pm$ & 1.0 & \\
\hline 107907 & Gonzales & Salinas R @ Gonzales Bridge & $01 / 28 / 2010$ & $<0.07$ & 25.2 & & $<0.12$ & 3.4 & 0.076 & 77 & $<0.23$ & 0.00035 & 0.00061 & 0.01591 & 0.00737 & 0.00041 & & $8.18 \pm 0.5$ & $6.86 \pm$ & 1.0 & \\
\hline 108008 & Gonzales & Salinas R @ Gonzales Bridge & 05/19/2010 & 0.04 & 38.9 & & $<0.12$ & 24.6 & 0.362 & 166 & & 0.00034 & 0.00020 & 0.01433 & 0.00704 & 0.00035 & & $7.51 \pm 0.5$ & $8.64 \pm$ & 1.0 & \\
\hline 108013 & Arroyo Seco & Arroyo Seco @ Arroyo Seco Rd Bridg & 05/19/2010 & $<0.07$ & 5.4 & & $<0.12$ & $<0.1$ & & 61 & & 0.00024 & & 0.01262 & 0.00634 & 0.00031 & & & & & \\
\hline 108363 & Chualar & Salinas R @ Chualar Bridge & 08/20/2010 & $<0.2$ & 14.0 & $<1$ & $<0.8$ & 0.5 & 0.020 & 57 & & & & & & & & & & & \\
\hline 108364 & Gonzales & Salinas $\mathrm{R} @$ Gonzzales Bridge & $08 / 20 / 2$ & $<0.2$ & 14.3 & $<1$ & 8 & $<0.8$ & & 57 & & & & & & & & & & & \\
\hline${ }_{108411}^{10484}$ & $\begin{array}{l}\text { Chualar } \\
\text { GGozzles }\end{array}$ & $\begin{array}{l}\text { Salinas R @ Chualar Bridge } \\
\text { Salinazs \& @ Gopzzles Bridge }\end{array}$ & $\begin{array}{l}09 / 13 / 2010 \\
0\end{array}$ & $<0.2$ & 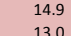 & $<1$ & $<0.8$ & 2.0 & 0.077 & 55 & & 0.00071 & 0.00017 & 0.01351 & 0.00669 & 0.00034 & & $8.13 \pm 0.5$ & $4.35 \pm$ & 1.0 & \\
\hline \multirow{2}{*}{108418} & $\begin{array}{l}\text { Gonzales } \\
\text { Arrovo Seco }\end{array}$ & Salinas R @ Gonzales Bridge & $\begin{array}{l}09 / 13 / 2010 \\
0\end{array}$ & $<0.2$ & 13.0 & $<1$ & $<0.8$ & 2.3 & 0.099 & 37 & & & 0.0011 & & & 0,00034 & & $7.17 \pm \quad 0.5$ & $4.58 \pm$ & 1.0 & \\
\hline & Arroyo Seco & Arroyo Seco @ Thorne Rd Bridge & 09/14/2010 & $<0.2$ & 10.7 & $<1$ & $<0$ & $<0$. & & & & & & & 0.00837 & 0.00034 & & & & & \\
\hline 8546 & Chualar & Salinas R @ Chualar Bridge & $11 / 05 / 2010$ & $<0.2$ & 32.1 & $<1$ & $<0.8$ & 6.5 & 0.116 & 91 & & & & & & & & $8.21 \pm 0.5$ & $8.99 \pm$ & 1.0 & \\
\hline \multicolumn{22}{|c|}{ 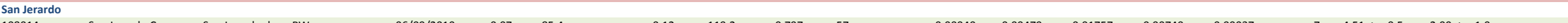 } \\
\hline 8014 & San Jerar & San Jera & $06 / 09 / 2$ & $<0.07$ & 85.4 & & $<0.12$ & 119.2 & 0.797 & 57 & & 0.00040 & 0.00479 & 0.01757 & 0.00740 & 0.00037 & $<7$ & $4.51 \pm 0.5$ & $2.09 \pm$ & 1.0 & \\
\hline 88191 & San Jera & San Jera & & $<0.0,0>0>0$ & 81.3 & & $<0.12$ & 108 & 0.759 & 30 & & 0.00070 & & 0.01840 & & & & $2.73 \pm 0.5$ & $2.33 \pm$ & .0 & \\
\hline 108197 & San Jerarc & San Jerat & 07 & $<0.07$ & 78.8 & & 0. & 10 & 0.734 & 26 & & & & & & & & & & & \\
\hline 083 & San Jera & sanjerar & 08 & 0. & 90.0 & $<1$ & $<$ & 106 & & 29 & & & & & & & & $2.43 \pm 0.5$ & & .0 & \\
\hline 1083 & San Jerardo Co & San Jerardo deep $\mathrm{PW}$ & $09 / 21 / 2$ & 0. & 89.7 & $<1$ & $<0$. & 99.3 & 0.633 & 29 & & 0.00064 & 0.00013 & 0.01732 & 00704 & 0.00039 & $<7$ & $3.26 \pm$ & $3.07 \pm$ & & \\
\hline 108366 & San Jerardo $C$ & San Jerardo deep PW & $10 / 13 / 2$ & $<0.2$ & 87.0 & $<1$ & $<0.8$ & 86.8 & 0.570 & 21 & & & & & & & & $3.99 \pm 0.5$ & $2.76 \pm$ & .0 & \\
\hline 108531 & San Jerardo $C$ & San Jerardo deep PW & $11 / 05 / 2010$ & $<0.2$ & 89.4 & $<1$ & $<0.8$ & 69.1 & 0.441 & 18 & & 0.00033 & 0.00011 & 0.01621 & 00608 & 0.00037 & $<7$ & $1.96 \pm 0.5$ & $3.18 \pm$ & .0 & \\
\hline 108595 & San Jerardo Co-op & San Jerardo shallow PW & $12 / 10 / 2010$ & $<0.2$ & 111.4 & $<1$ & $<0.8$ & 35.2 & 0.181 & 19 & & & & & & & & & & & \\
\hline 108596 & San Jerardo Co-op & San Jerardo deep PW & $12 / 10 / 2010$ & $<0.2$ & 82.8 & $<1$ & $<0.8$ & 130.4 & 0.900 & 35 & & & & & & & & & & & \\
\hline
\end{tabular}


Table 1c. Groundwater age-related analytical results.

\begin{tabular}{|c|c|c|c|c|c|c|c|c|c|c|c|c|c|c|c|c|c|}
\hline LNLLID & Area & Location ID & Sample Date & $\begin{array}{c}3 \mathrm{H} \\
(\mathrm{pC} / \mathrm{L})\end{array}$ & $\begin{array}{c}\text { 3He//4he } \\
\text { (atom ratio) }\end{array}$ & $\begin{array}{c}4 \mathrm{He} \\
\text { (cm3 STP/g H2O) }\end{array}$ & $\begin{array}{c}\mathrm{Ne} \\
\text { (cm3 STP/g H20) }\end{array}$ & $\begin{array}{c}\mathrm{Ar} \\
\text { (cm3 str/g H2O) }\end{array}$ & $\begin{array}{c}\mathrm{kr} \\
\text { (cm3 STP/g H20) }\end{array}$ & $\begin{array}{c}\text { Xe } \\
\text { (cm3 STP/g H20) }\end{array}$ & $\begin{array}{c}\text { Excess Air } \\
\text { (cm3STr/g H20) }\end{array}$ & $\begin{array}{c}\begin{array}{c}\text { Tritiogenic } \\
\text { 3He } \\
\text { (cm3 sTP/g } \\
\text { H2O) }\end{array} \\
\end{array}$ & $\begin{array}{l}\begin{array}{c}\text { GW age }(y r), \\
\text { corrected }\end{array} \\
\end{array}$ & $\begin{array}{c}\begin{array}{c}\text { Pre- } \\
\text { modern }\end{array} \\
\end{array}$ & $\begin{array}{l}\text { Recharge Temp } \\
\text { ("c) }\end{array}$ & 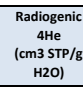 & 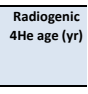 \\
\hline $\begin{array}{l}\text { Monotitor } \\
107809\end{array}$ & & & 12//22/20099 & & & & & & & & & & & & & & \\
\hline $\begin{array}{l}107811 \\
1078712\end{array}$ & $\begin{array}{l}\text { Arroyo Seco } \\
\text { AArrov Seco }\end{array}$ & $\begin{array}{l}185 / 66-26601 \\
18556-26603\end{array}$ & $\begin{array}{l}12 / 222 / 2009 \\
112 / 2202009\end{array}$ & $\begin{array}{l}5.2 \pm 0.33 \\
5.5 \pm 0.34\end{array}$ & & $6.60 E-08 \pm 1.32 E-09$ & $2.94 E-07 \pm 5.88 E-09$ & $3.94 E-04 \pm 7.87 E-06$ & $7.89 E-08 \pm 2.377-09$ & $1.08 E-08 \pm 3.24 E-10$ & $0.0058 \pm 0.0003$ & nd & $<1$ & $<10 \%$ & $17.9 \pm 1.3$ & $<1 E-09$ & \\
\hline $\begin{array}{l}107812 \\
107813 \\
\end{array}$ & $\begin{array}{l}\text { Arrove Seco } \\
\text { Arroy seco }\end{array}$ & 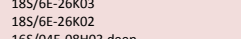 & $\begin{array}{l}12 / 222 / 22009 \\
12 / 22 / 2009\end{array}$ & $\begin{array}{l}5.5 \pm 0.34 \\
6.3 \pm 0.39\end{array}$ & $\begin{array}{l}\begin{array}{l}1.1343-06 \\
1.39-06\end{array} \\
1\end{array}$ & $\begin{array}{l}4.87 z-0.0 \pm 9.7 .736-10 \\
1.07 z=07 \pm 2.14-09\end{array}$ & $\begin{array}{l}2.186-0.0 \pm+4.366-09 \\
4.176-07 \pm 8.35-09\end{array}$ & $\begin{array}{l}3.43 E-0446.8666-06 \\
4.61--04 \pm 9.22 E-06\end{array}$ & 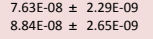 & $\begin{array}{l}1.14 E E-8 \pm \pm 3.436 E-10 \\
1.242-08 \pm 3.72 E-10\end{array}$ & $\begin{array}{l}0.0016 \text { 0.0.0002 } \\
0.0126 \pm 0.0005\end{array}$ & $\begin{array}{c}\text { nd } \\
1.24 \mathrm{E}-15\end{array}$ & $l_{4 \pm 1}^{1}$ & $\begin{array}{l}<10 \% \\
<10 \%\end{array}$ & 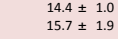 & 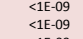 & \\
\hline $\begin{array}{l}107901 \\
107902\end{array}$ & $\begin{array}{l}\text { Chualar } \\
\text { Chualar }\end{array}$ & 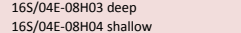 & $\begin{array}{l}01 / 288 / 21010 \\
01 / 28 / 2010\end{array}$ & $\begin{array}{l}6.7 \pm 0.45 \\
5.3 \pm 0.88\end{array}$ & $\begin{array}{l}1.55 E-06 \\
1.444-06\end{array}$ & $\begin{array}{ll}6.016-0.8 \pm & \pm 1.20 \mathrm{E}-0.9 \\
6.26-08 & 1.25-09\end{array}$ & $\begin{array}{l}2.45 E-07 \pm 1.25 E-80 \\
2.45-07 \pm 1.255-08\end{array}$ & $\begin{array}{l}3.45 E-0 \pm \pm 6.90 E-06 \\
3.545-04 \pm 7.08 E E-06\end{array}$ & $\begin{array}{l}7.48 E-08 \pm 2.242-09 \\
7.565-08+2.27-09\end{array}$ & $\begin{array}{l}1.111--08 \pm 3.344-10-10 \\
1.177-08 \pm 3.511-10\end{array}$ & $\begin{array}{l}0.0031 \pm 0.0003 \\
0.0003 \pm \pm 0.0003\end{array}$ & $\begin{array}{l}1.08 E-14 \\
626-15\end{array}$ & $\begin{array}{l}20 \pm 1 \\
17 \pm 1\end{array}$ & $\begin{array}{l}49 \% \\
41 \% \%\end{array}$ & $\begin{array}{l}16.0 \pm 1.1 \\
144+10\end{array}$ & $\begin{array}{r}<1 E-09 \\
126 E-09\end{array}$ & 30 \\
\hline 107904 & $\begin{array}{l}\text { Chualar } \\
\text { Gonzales }\end{array}$ & 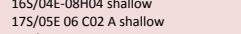 & $\begin{array}{l}\begin{array}{l}10 / 1 / 288 / 21010 \\
01 / 28 / 2010\end{array} \\
0\end{array}$ & $\begin{array}{l}5.3 \pm 0.88 \\
7.1 \pm 0.48\end{array}$ & $\begin{array}{l}1.44 E-06 \\
1.37-06\end{array}$ & $\begin{array}{l}6.266-08 \pm 1.252-090 \\
5.85-08 \pm 1.17-09\end{array}$ & $\begin{array}{l}2.455-07 \pm 1.255-08 \\
2.53 E-07 \pm 1.30 E-08\end{array}$ & & $\begin{array}{l}7.566-08 \pm 2.277-09 \\
6.57-08 \pm 1.976-09\end{array}$ & & $\begin{array}{l}0.00000 \pm 0.00003 \\
0.0036 \pm 0.0003\end{array}$ & $\begin{array}{l}6.266-15 \\
2.24-16\end{array}$ & $\begin{array}{r}17 \pm 1 \\
1 \pm 1\end{array}$ & $\begin{array}{l}41 \% \\
<<0 \%\end{array}$ & & $\begin{array}{l}1.26 E-09 \\
<1 \mathrm{E}-09\end{array}$ & 30 \\
\hline 107905 & $\begin{array}{l}\text { Gonzales } \\
\text { Gonats }\end{array}$ & $175 / 05 \mathrm{O} 06 \mathrm{CO1} 1 \mathrm{~B}$ deep & 28/2010 & $6.4 \pm 0.40$ & $\begin{array}{l}1.477-06 \\
1.760\end{array}$ & $4.89 E-08 \pm 9.78 E-10$ & $2.20 E-07 \pm 1.13 E-08$ & $3.22 E-04 \pm 6.43 E-06$ & $7.088-08 \pm 2.12 E-09$ & $\begin{array}{l}1.01 E-08 \pm 3.02 E-10 \\
1\end{array}$ & $0.0018 \pm 0.0002$ & 4.906-15 & $12 \pm 1$ & $<10 \%$ & $18.9 \pm 1.0$ & $<1 E-09$ & \\
\hline $\begin{array}{l}108009 \\
108010\end{array}$ & $\begin{array}{l}\text { Gonzales } \\
\text { Gonzales }\end{array}$ & 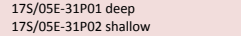 & $\begin{array}{l}05 / 19 / 21010 \\
05 / 19 / 2010\end{array}$ & $\begin{array}{l}6.0 \pm 0.40 \\
6.2 \pm 0.41\end{array}$ & 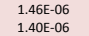 & $\begin{array}{l}4.5 .5 E-0.0 \pm 9.166-10 \\
6.588-08 \pm 1.32 E-09\end{array}$ & $\begin{array}{l}1.986-0.7 \pm 5.388-09 \\
2.818-07 \pm 5.62-09\end{array}$ & 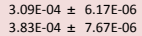 & $\begin{array}{l}7.03 E-0.0 \pm 2.1115-09 \\
7.822-08 \pm 2.35 E-09\end{array}$ & $\begin{array}{l}9.63-5 E=9 \pm 2.897-10 \\
1.02-08 \pm 3.076-10\end{array}$ & $\begin{array}{l}0.0008 \pm 0.0002 \\
0.0051 \pm \pm 0.0003\end{array}$ & 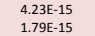 & $\begin{aligned} 12 \pm 1 \\
6 \pm 3\end{aligned}$ & $\begin{array}{l}<10 \% \\
<10 \%\end{array}$ & $\begin{array}{l}20.7 \pm 1.0 \\
19.7 \pm 1.3\end{array}$ & 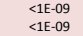 & \\
\hline $\begin{array}{l}\begin{array}{l}1008010 \\
1080011\end{array} \\
\end{array}$ & $\begin{array}{l}\text { Sonzeles } \\
\text { soledad }\end{array}$ & 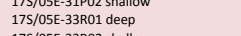 & $\begin{array}{l}55 / 19 / 210 \\
05 / 19 / 2010\end{array}$ & $\begin{array}{l}6.2 \pm 0.41 \\
6.2 \pm 0.45\end{array}$ & $\begin{array}{l}1.406-06 \\
1.47-.06\end{array}$ & $\begin{array}{l}6.558-0.0 \pm 1.3221-09 \\
6.577-08 \pm 1.31-09\end{array}$ & $\begin{array}{l}2.281 E-7 \pm 5 \pm 5.62 E-09 \\
2.44 E-07 \pm 4.89--09\end{array}$ & $\begin{array}{l}3.88 E-04+7.676-06 \\
3.99 E-04 \pm 6.98 E-06\end{array}$ & 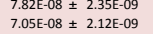 & $\begin{array}{l}1.022-08 \pm 3.0 .077-10 \\
9.90 E-09 \pm 2.97 E-10\end{array}$ & $\begin{array}{l}0.0051 \pm 0.00003 \\
0.0031 \pm 0.0003\end{array}$ & 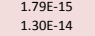 & $\begin{aligned} & 6 \pm 3 \\
& 23 \pm 1\end{aligned}$ & $\begin{array}{l}<10 \% \\
68 \%\end{array}$ & $\begin{array}{l}19.7 \pm 1.3 \\
19.9 \pm 1.1\end{array}$ & $\begin{array}{l}\text { rete.09 } \\
4.43 E-09 \\
4\end{array}$ & 90 \\
\hline $\begin{array}{l}108012 \\
108409\end{array}$ & $\begin{array}{l}\text { Soledad } \\
\text { Chualar }\end{array}$ & 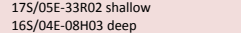 & & $\begin{array}{l}5.1 \pm 0.43 \\
6.0 \pm 0.44\end{array}$ & $\begin{array}{l}1.42 E-06 \\
1.54=06\end{array}$ & 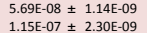 & $\begin{array}{l}2.29 E-07 \pm 4.575-09 \\
3.399-07+6.788-09\end{array}$ & $\begin{array}{l}3.46 \mathrm{E}-0 \pm \pm 6.92 \mathrm{E}-06 \\
3.85 \mathrm{E}-04 \pm 7.71 \mathrm{E}\end{array}$ & $\begin{array}{l}7.26 E-08 \pm 2.188-09 \\
8.111-08+2.43-09\end{array}$ & $\begin{array}{l}1.012-08 \pm 3.02 E-10 \\
1.032-08+3.088-10\end{array}$ & $\begin{array}{l}0.0022 \pm 0.0003 \\
0.0082+0.0004\end{array}$ & $\begin{array}{l}3.61 E-15 \\
5.49-14\end{array}$ & $\begin{array}{l}10 \pm 2 \\
26 \pm 2\end{array}$ & $\begin{array}{l}<10 \% \\
79 \%\end{array}$ & $\begin{array}{l}19.0 \pm 1.1 \\
172 \pm 17\end{array}$ & $\begin{array}{l}4.23 E-10 \\
2.62-08\end{array}$ & $\begin{array}{l}10 \\
500 \\
500\end{array}$ \\
\hline $\begin{array}{l}\begin{array}{l}108499 \\
108410\end{array} \\
\end{array}$ & $\begin{array}{l}\text { Chualar } \\
\text { Chualar }\end{array}$ & 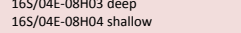 & $\begin{array}{l}09 / 13 / 2010 \\
09 / 13 / 2010\end{array}$ & $\begin{array}{l}6.0 \pm 0.44 \\
6.0 \pm 0.51\end{array}$ & $\begin{array}{l}1.54 E-06 \\
1.40 E-06\end{array}$ & 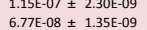 & $\begin{array}{l}3.399-07 \pm 6.7 .78-E-59 \\
2.58 E-07 \pm 5.15 E-09\end{array}$ & $\begin{array}{l}3.85 \mathrm{EE-04} \pm 7.7 .7 E-06 \\
3.50 \mathrm{E}-04 \pm 7.00 \mathrm{E}-06\end{array}$ & 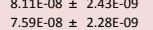 & $\begin{array}{l}1.032-08 \pm 3.088-10 \\
1.00 E-08 \pm 3.01 E-10\end{array}$ & $\begin{array}{l}0.00822 \pm 0.0004 \\
0.0037 \pm 0.0003\end{array}$ & $\begin{array}{l}5.496-14 \\
\text { 5.04E-15 }\end{array}$ & $\begin{array}{l}26 \pm 2 \\
13 \pm 1\end{array}$ & $\begin{array}{l}79 \% \\
13 \%\end{array}$ & $\begin{array}{l}17.2 \pm 1.7 \\
16.8 \pm 1.2\end{array}$ & $\begin{array}{l}2.622 .08 \\
2.43 E-09\end{array}$ & $\begin{array}{l}500 \\
50\end{array}$ \\
\hline 108412 & $\begin{array}{l}\text { Gonales } \\
\text { Gonzles }\end{array}$ & 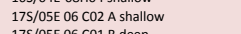 & o9/13/2010 & $6.8 \pm 0.50$ & $\begin{array}{l}1.398-06 \\
1.06\end{array}$ & $7.63 \mathrm{E}-08 \pm 1.53 \mathrm{E}-0.0$ & $3.29 E-07 \pm 6.57 \mathrm{E}-09$ & $4.01 E-04 \pm 8.03 E-06$ & $8.522-08 \pm 2.55 E-09$ & $1.12 E-08 \pm 3.37 \mathrm{z}-10$ & $0.0078 \pm 0.0004$ & $7.80 E-16$ & $2 \pm 3$ & $<10 \%$ & $18.5 \pm 1.5$ & $\begin{array}{l}2.45-09 \\
<1 E-09\end{array}$ & \\
\hline $\begin{array}{l}108413 \\
108415\end{array}$ & $\begin{array}{l}\text { Gonzales } \\
\text { Gozales }\end{array}$ & & $\begin{array}{l}09 / 13 / 2010 \\
00 / 132010\end{array}$ & $6.4 \pm 0.46$ & $\begin{array}{l}1.46 E-06 \\
1.40-06\end{array}$ & $\begin{array}{l}4.85 E-08 \pm 9.71 E-10 \\
\end{array}$ & $2.08 E-07 \pm 4.16 E-09$ & $3.13 E-04 \pm 6.27 E-06$ & $6.83 E-08 \pm 2.05 E-09$ & $9.744-09 \pm 2.922-10$ & $0.0011 \pm 0.0002$ & $\begin{array}{l}4.63 E-15 \\
1595-15\end{array}$ & $12 \pm 1$ & $<10 \%$ & NC $\pm N A$ & <1E-09 & \\
\hline 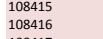 & $\begin{array}{l}\text { Gonzales } \\
\text { Gonzales }\end{array}$ & 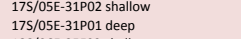 & 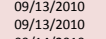 & $\begin{array}{l}5.9 \pm 0.0 .39 \\
5.5 \pm 1.35\end{array}$ & $\begin{array}{l}\begin{array}{l}1.4060 .06 \\
1.48 E-06\end{array} \\
\end{array}$ & 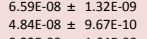 & 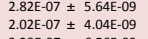 & $\begin{array}{l}3.896-04 \pm \pm .799-06 \\
2.97-04 \pm 5.94-06\end{array}$ & $\begin{array}{l}8.828 \mathrm{E}-80 \pm 2.4885-09 \\
6.83-08 \pm 2.05 E-09\end{array}$ & $\begin{array}{l}1.111-E=8 \pm 3.336-10 \\
8.82 E-09 \pm 2.65 E-10\end{array}$ & $\begin{array}{l}0.0052 \pm 0.00003 \\
0.0008 \pm 0.0002\end{array}$ & $\begin{array}{l}\begin{array}{l}1.1595-15 \\
5.37-15\end{array} \\
5\end{array}$ & $\begin{array}{r}5 \pm 3 \\
15 \pm 3\end{array}$ & $\begin{array}{l}<10 \% \\
27 \%\end{array}$ & $17.6 \pm 1.2$ & 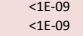 & \\
\hline $\begin{array}{l}108417 \\
108419\end{array}$ & $\begin{array}{l}\text { Arroyo Seco } \\
\text { Soledad }\end{array}$ & 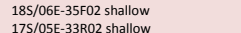 & $\begin{array}{l}09 / 14 / 2010 \\
090142010\end{array}$ & $6.4 \pm 0.39$ & $\begin{array}{l}1.39 E-06 \\
1.44-06\end{array}$ & $\begin{array}{l}8.22 E-08 \pm 1.64 E-09 \\
58.165\end{array}$ & $3.28 E-07 \pm 6.565-09$ & $3.62 E-04 \pm 7.246-06$ & $7.466-08 \pm 2.242-09$ & $\begin{array}{l}1.05 E-08 \pm 3.144-10 \\
1.0202020\end{array}$ & $0.0075 \pm 0.0004$ & $1.646-15$ & $5 \pm 3$ & $<10 \%$ & & $<11-09$ & \\
\hline $\begin{array}{l}1084920 \\
108420\end{array}$ & $\begin{array}{l}\text { Soledad } \\
\text { Soledad }\end{array}$ & 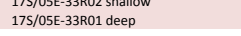 & $\begin{array}{l}09 / 14 / 2010 \\
09 / 14 / 2010\end{array}$ & $\begin{array}{l}5.5 \pm 0.42 \\
7.6 \pm 0.53\end{array}$ & & $\begin{array}{l}5.81-08 \pm 1.166-099 \\
6.81-08 \pm 1.36 \mathrm{E}-09\end{array}$ & $\begin{array}{l}2.38-07 \pm 4.755-09 \\
3.02 E-07 \pm 6.04 E-09\end{array}$ & 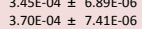 & 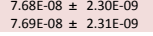 & $\begin{array}{l}1.1020-E 8 \pm 3.0 .077-10 \\
9.79-09 \pm 2.94 E-10\end{array}$ & $\begin{array}{l}0.0027 \pm 0.00003 \\
0.0063 \pm 0.0003\end{array}$ & $\begin{array}{l}3.916-15 \\
5.24-15\end{array}$ & $\begin{array}{l}12 \pm 2 \\
11 \pm 2\end{array}$ & $\begin{array}{l}12 \% \\
<<0 \%\end{array}$ & $\begin{array}{l}17.3 \pm 1.1 \\
17.8 \pm 1.5\end{array}$ & 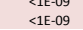 & \\
\hline $\begin{array}{l}\text { Surface W } \\
107810\end{array}$ & & & & & & & & & & & & & & & & & \\
\hline & & 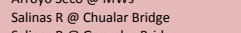 & 104227 & \pm 0.42 & & & & & & & & & & & & & \\
\hline $\begin{array}{l}107907 \\
108008\end{array}$ & $\begin{array}{l}\text { Gonzales } \\
\text { Gonnales }\end{array}$ & $\begin{array}{l}\text { Salinas R @ Gonzales sridge } \\
\text { Salinas R@Gonales Bridge }\end{array}$ & $\begin{array}{l}01 \\
05 / \\
0.51\end{array}$ & $\begin{array}{ll}2.6 \pm & \pm 0.70 \\
6.5 \pm & 0.01\end{array}$ & & & & & & & & & & & & & \\
\hline $\begin{array}{l}100013 \\
1083363\end{array}$ & $\begin{array}{l}\text { Arroyo Seco } \\
\text { Chuale }\end{array}$ & $\begin{array}{l}\text { Arroyo Seco @ A Arrovo Seco Rd Bridge } \\
\text { Salinas R @ C Cuular r rigde }\end{array}$ & $\begin{array}{l}05 / 19 / 2010 \\
0 / 20 / 2010\end{array}$ & $\begin{array}{ll}7.4 & \pm 0.47 \\
5.5 & \pm 0.79\end{array}$ & & & & & & & & & & & & & \\
\hline 108364 & $\begin{array}{l}\text { chanar } \\
\text { Gonzales }\end{array}$ & 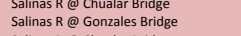 & $08 / 20 / 2010$ & $\begin{array}{l}5.2 \pm 0.68 \\
5.2\end{array}$ & & & & & & & & & & & & & \\
\hline $\begin{array}{l}108411 \\
108414\end{array}$ & $\begin{array}{l}\text { Chualar } \\
\text { Gonzales }\end{array}$ & $\begin{array}{l}\text { Salinas R @ @ Chua } \\
\text { Salinas } @ \text { G Gonz }\end{array}$ & $\begin{array}{l}09 / 131 \\
099 / 13\end{array}$ & & & & & & & & & & & & & & \\
\hline $\begin{array}{l}108418 \\
108546\end{array}$ & $\begin{array}{l}\text { Arryoy Seco } \\
\text { Chualer }\end{array}$ & 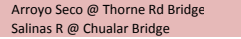 & $\begin{array}{l}09 / 14 / 2 / 210 \\
11 / 0 / 2010\end{array}$ & $\begin{array}{l}6.4 \pm 0.05 \\
6.4 \pm 0.65\end{array}$ & & & & & & & & & & & & & \\
\hline $\begin{array}{l}\text { San Jerard } \\
108014\end{array}$ & San Jerardo o & San Jerardo do & 06/09/2 & & & & & & $-08 \pm$ & \pm 2 & 11 & & & & & & \\
\hline 8191 & & $\begin{array}{l}\text { San Jerarc } \\
\text { San Jerar }\end{array}$ & $07 / 071$ & & & $07 \pm 2.698-09$ & & $\begin{array}{l}4 \pm 7.29 \mathrm{E}-06 \\
4 \pm 7.52-06\end{array}$ & \pm & \pm 3 & $\begin{array}{l}9 \pm 0.0003 \\
2+0.0004\end{array}$ & & & & & $\begin{array}{l}5.8 \\
6.3 \\
6\end{array}$ & \\
\hline 108362 & $\begin{array}{l}\text { San Jerardococo-op } \\
\text { San Jerardo Co-op }\end{array}$ & $\begin{array}{l}\text { ananerardo odeep PW } \\
\text { San Jerardo deep PW }\end{array}$ & $\begin{array}{c}07 / 28 \\
08 / 20\end{array}-30$ & $\begin{array}{ll}1.3 & \pm 0.28 \\
1.5 & \pm 0.26\end{array}$ & $\begin{array}{l}8.206 E-07 \\
5.94-07\end{array}$ & $\begin{array}{l}1.39-07 \pm 2 . \\
1.43-07 \pm 2 .\end{array}$ & E-09 & $\begin{array}{l}3.36-0-04 \pm 7 \\
3.58-04 \pm 7\end{array}$ & $\begin{array}{l}7.753-E-8 \pm 2.266-09 \\
7.53-08 \pm 2.26-09\end{array}$ & $\begin{array}{l}9.821--9 \pm \pm 2.955-10 \\
99.61-09 \pm 3.08-10\end{array}$ & $\begin{array}{l}0.0002 \pm 0.00004 \\
0.0046 \pm 0.0003\end{array}$ & & & & & & $\begin{array}{l}1300 \\
1500\end{array}$ \\
\hline 108365 & San Jerardo Co-op & San Jerardo deep $\mathrm{PW}$ & $09 / 21 / 2010$ & $1.5 \pm 0.36$ & $7.856-07$ & $1.16 \mathrm{E}-07 \pm 2.33 \mathrm{E}-09$ & $2.68 E-07 \pm 9.011-09$ & $3.58 \mathrm{E}-04 \pm 7.17 \mathrm{E}-06$ & 7.56-08 $\pm 2.27 \mathrm{E}-09$ & 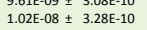 & $0.0045 \pm 0.0003$ & & & & & & 1000 \\
\hline $\begin{array}{l}108366 \\
108531\end{array}$ & $\begin{array}{l}\text { San Jerardo co-op } \\
\text { San Jerardo co-op }\end{array}$ & $\begin{array}{l}\text { San Jerardo deeep } \mathrm{PW} \\
\text { San Jerardo oep } \mathrm{PW}\end{array}$ & $\begin{array}{l}10 / 13 / 2 / 2010 \\
110502010\end{array}$ & & $\begin{array}{l}5.944-07 \\
.394-07\end{array}$ & $\begin{array}{l}1.61 E-07 \pm 3.22 E-09 \\
2.54-07 \pm 5.08-09\end{array}$ & $\begin{array}{l}2.76-07 \pm 5.525-09 \\
2.76-07+5.525-09\end{array}$ & $\begin{array}{l}3.53 E-04 \pm 7.07 E-06 \\
3.575-0.456-06\end{array}$ & $7.27 E-08 \pm 2.188-09$ & $9.466-09 \pm 2.896-10$ & $0.0055 \pm 0.0003$ & & & & $19.5 \pm 1.5$ & $\begin{array}{l}8.522-08 \\
1840.07\end{array}$ & $\begin{array}{l}1700 \\
3700\end{array}$ \\
\hline 10595 & 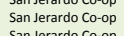 & 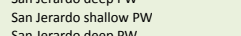 & $\begin{array}{l}17251 / 2010 \\
12 / 10210\end{array}$ & & & & & & & & & & & & & & \\
\hline & & & & & & & & & & & & & & & & & \\
\hline
\end{tabular}


Table 1d. Analytical results for stable isotopes of the water molecule, inorganic and organic carbon, and dissolved radon.

\begin{tabular}{|c|c|c|c|c|c|c|c|c|c|c|}
\hline LLNL ID & Area & Location ID & Sample Date & $\begin{array}{c}\delta 180 \\
(\%, \text { SMOW) }\end{array}$ & $\begin{array}{c}\delta D \\
(\%, \text { SMOW) }\end{array}$ & $\begin{array}{c}\text { DIC } \\
\text { (mg/L as C) }\end{array}$ & $\begin{array}{c}\text { TOC } \\
\text { (mg/L as C) }\end{array}$ & $\begin{array}{c}\delta 13 \mathrm{C} \text { of DIC } \\
\text { (\%o pdb) }\end{array}$ & $\begin{array}{l}\text { 222Rn } \\
\text { (pCi/L) }\end{array}$ & \\
\hline \multicolumn{11}{|c|}{ Monitor Wells } \\
\hline 107809 & Arroyo Seco & 18S/6E-26L01 & $12 / 22 / 2009$ & -7.02 & -46 & 32.4 & 1.62 & -9.30 & 397 & 20 \\
\hline 107811 & Arroyo Seco & 18S/6E-26K01 & $12 / 22 / 2009$ & -6.68 & -46 & 37.7 & 1.55 & -8.99 & $381 \pm$ & 19 \\
\hline 107812 & Arroyo Seco & $18 \mathrm{~S} / 6 \mathrm{E}-26 \mathrm{~K} 03$ & $12 / 22 / 2009$ & -6.94 & -44 & 34.0 & 1.79 & -9.18 & $378 \pm$ & 40 \\
\hline 107813 & Arroyo Seco & 18S/6E-26K02 & $12 / 22 / 2009$ & -7.11 & -48 & 27.8 & 1.12 & -7.71 & $361 \pm$ & 27 \\
\hline 107901 & Chualar & 16S/04E-08H03 deep & 01/28/2010 & -5.25 & -36 & 46.8 & 2.69 & -11.35 & $371 \pm$ & 19 \\
\hline 107902 & Chualar & 16S/04E-08H04 shallow & 01/28/2010 & -4.80 & -33 & 41.6 & 2.71 & -10.70 & $234 \pm$ & $=12$ \\
\hline 107904 & Gonzales & 17S/05E 06 C02 A shallow & 01/28/2010 & -3.00 & -25 & 36.7 & 3.05 & -9.68 & $245 \pm$ & 13 \\
\hline 107905 & Gonzales & 17S/05E 06 C01 B deep & 01/28/2010 & -5.11 & -36 & 37.4 & 2.39 & -9.75 & $239 \pm$ & 13 \\
\hline 108009 & Gonzales & 17S/05E-31P01 deep & 05/19/2010 & -4.80 & -34 & & & & $68 \pm$ & 8 \\
\hline 108010 & Gonzales & 17S/05E-31P02 shallow & 05/19/2010 & -4.49 & -33 & & & & $233 \pm$ & 13 \\
\hline 108011 & Soledad & 17S/05E-33R01 deep & 05/19/2010 & -6.57 & -41 & 67.9 & 2.70 & -12.46 & $16 \pm$ & 6 \\
\hline 108012 & Soledad & 17S/05E-33R02 shallow & 05/19/2010 & -6.94 & -42 & & & & $556 \pm$ & 28 \\
\hline 108409 & Chualar & 16S/04E-08H03 deep & 09/13/2010 & -4.50 & -34 & & & & $454 \pm$ & 24 \\
\hline 108410 & Chualar & 16S/04E-08H04 shallow & 09/13/2010 & -5.02 & -35 & & & & $455 \pm$ & 24 \\
\hline 108412 & Gonzales & 17S/05E 06 C02 A shallow & 09/13/2010 & -5.40 & -35 & & & & $294 \pm$ & 18 \\
\hline 108413 & Gonzales & 17S/05E 06 C01 B deep & 09/13/2010 & -4.74 & -34 & & & & $289 \pm$ & 18 \\
\hline 108415 & Gonzales & 17S/05E-31P02 shallow & 09/13/2010 & -4.62 & -34 & & & & $244 \pm$ & 17 \\
\hline 108416 & Gonzales & 17S/05E-31P01 deep & 09/13/2010 & -4.30 & -32 & & & & $26 \pm$ & 9 \\
\hline 108417 & Arroyo Seco & 18S/06E-35F02 shallow & 09/14/2010 & -7.51 & -47 & & & & $453 \pm$ & 23 \\
\hline 108419 & Soledad & 17S/05E-33R02 shallow & 09/14/2010 & -6.54 & -45 & & & & $755 \pm$ & $=38$ \\
\hline 108420 & Soledad & 17S/05E-33R01 deep & 09/14/2010 & -6.60 & -42 & & & & $<11$ & \\
\hline \multicolumn{11}{|c|}{ Surface Water } \\
\hline 107810 & Arroyo Seco & Arroyo Seco@ MWs & $12 / 22 / 2009$ & -6.92 & -45 & 29.9 & 2.22 & -7.46 & $<6$ & \\
\hline 107903 & Chualar & Salinas R @ Chualar Bridge & 01/28/2010 & -7.02 & -44 & 30.1 & 4.14 & -10.26 & $<8$ & \\
\hline 107907 & Gonzales & Salinas R @ Gonzales Bridge & 01/28/2010 & -6.80 & -44 & 30.9 & 4.22 & -10.07 & $<8$ & \\
\hline 108008 & Gonzales & Salinas R @ Gonzales Bridge & 05/19/2010 & -5.90 & -38 & & & & $<8$ & \\
\hline 108013 & Arroyo Seco & Arroyo Seco@ Arroyo Seco Rd Bridge & 05/19/2010 & -7.67 & -47 & 29.7 & 2.03 & -6.93 & $<8$ & \\
\hline 108363 & Chualar & Salinas R @ Chualar Bridge & 08/20/2010 & -5.37 & -32 & & & & $<18$ & \\
\hline 108364 & Gonzales & Salinas R @ Gonzales Bridge & 08/20/2010 & -4.69 & -33 & & & & $<20$ & \\
\hline 108411 & Chualar & Salinas R @ Chualar Bridge & 09/13/2010 & -5.02 & -33 & & & & $<12$ & \\
\hline 108414 & Gonzales & Salinas R @ Gonzales Bridge & 09/13/2010 & & & & & & $<12$ & \\
\hline 108418 & Arroyo Seco & Arroyo Seco @ Thorne Rd Bridge & 09/14/2010 & -7.11 & -45 & & & & $<11$ & \\
\hline 108546 & Chualar & Salinas R @ Chualar Bridge & $11 / 05 / 2010$ & -5.26 & -33 & & & & $<17$ & \\
\hline \multicolumn{11}{|c|}{ San Jerardo } \\
\hline 108014 & San Jerardo Co-op & San Jerardo deep PW & 06/09/2010 & -3.10 & -34 & 22.4 & 1.40 & -16.44 & $1,904 \pm$ & $=95$ \\
\hline 108191 & San Jerardo Co-op & San Jerardo deep PW & 07/07/2010 & -4.10 & -37 & 24.2 & 2.09 & -13.59 & $1,754 \pm$ & $=88$ \\
\hline 108197 & San Jerardo Co-op & San Jerardo deep PW & 07/28/2010 & -3.15 & -35 & 25.9 & 2.11 & -14.64 & $1,632 \pm$ & $=82$ \\
\hline 108362 & San Jerardo Co-op & San Jerardo deep PW & 08/20/2010 & -7.25 & -44 & & & & $1,650 \pm$ & $=82$ \\
\hline 108365 & San Jerardo Co-op & San Jerardo deep PW & 09/21/2010 & -6.76 & -45 & & & & $1,687 \pm$ & $=84$ \\
\hline 108366 & San Jerardo Co-op & San Jerardo deep PW & $10 / 13 / 2010$ & -6.69 & -45 & & & & $1,813 \pm$ & \\
\hline 108531 & San Jerardo Co-op & San Jerardo deep PW & $11 / 05 / 2010$ & -6.72 & -44 & & & & $2,047 \pm$ & $=102$ \\
\hline 108595 & San Jerardo Co-op & San Jerardo shallow PW & $12 / 10 / 2010$ & -6.72 & -44 & & & & & \\
\hline 108596 & San Jerardo Co-op & San Jerardo deep PW & $12 / 10 / 2010$ & -7.26 & -44 & & & & & \\
\hline
\end{tabular}

